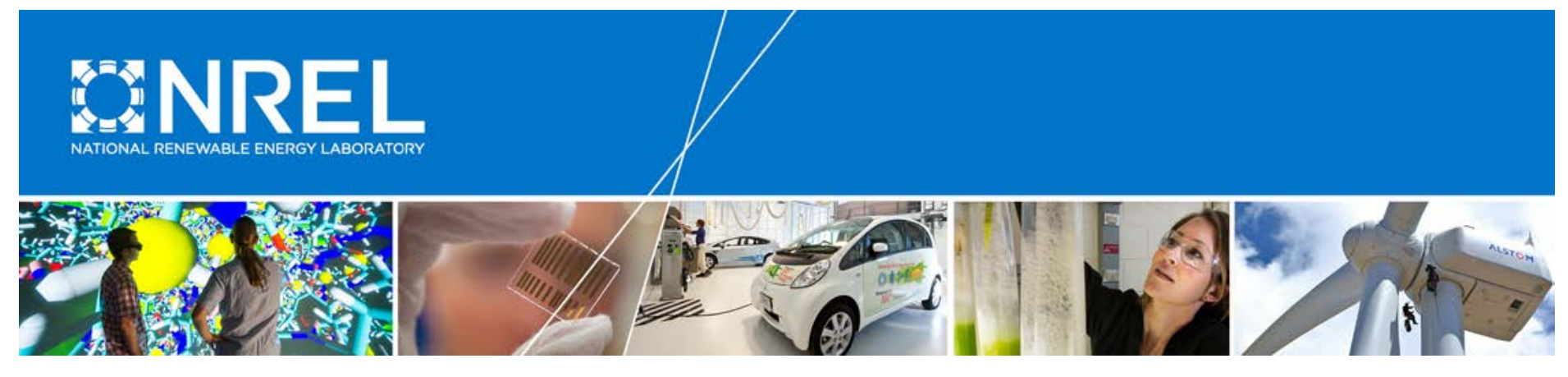

\title{
Comparing Photovoltaic (PV) Costs and Deployment Drivers in the Japanese and U.S. Residential and Commercial Markets
}

B. Friedman and R. Margolis

National Renewable Energy Laboratory (NREL)

J. Seel

Lawrence Berkeley National Laboratory (LBNL)

NREL is a national laboratory of the U.S. Department of Energy Office of Energy Efficiency \& Renewable Energy Operated by the Alliance for Sustainable Energy, LLC

This report is available at no cost from the National Renewable Energy Laboratory (NREL) at www.nrel.gov/publications.

Technical Report

NREL/TP-6A20-60360

Revised April 2016

Contract No. DE-AC36-08G028308 


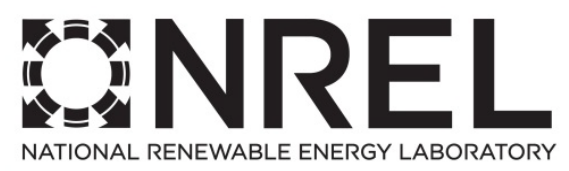

\section{Comparing Photovoltaic (PV) Costs and Deployment Drivers in the Japanese and U.S. Residential and Commercial Markets}

B. Friedman and R. Margolis

National Renewable Energy Laboratory (NREL)

J. Seel

Lawrence Berkeley National Laboratory (LBNL)

Prepared under Task No. SM13.0570

NREL is a national laboratory of the U.S. Department of Energy Office of Energy Efficiency \& Renewable Energy Operated by the Alliance for Sustainable Energy, LLC

This report is available at no cost from the National Renewable Energy Laboratory (NREL) at www.nrel.gov/publications.

National Renewable Energy Laboratory 15013 Denver West Parkway Golden, CO 80401 303-275-3000 • www.nrel.gov
Technical Report NREL/TP-6A20-60360

Revised April 2016

Contract No. DE-AC36-08GO28308 


\section{NOTICE}

This report was prepared as an account of work sponsored by an agency of the United States government. Neither the United States government nor any agency thereof, nor any of their employees, makes any warranty, express or implied, or assumes any legal liability or responsibility for the accuracy, completeness, or usefulness of any information, apparatus, product, or process disclosed, or represents that its use would not infringe privately owned rights. Reference herein to any specific commercial product, process, or service by trade name, trademark, manufacturer, or otherwise does not necessarily constitute or imply its endorsement, recommendation, or favoring by the United States government or any agency thereof. The views and opinions of authors expressed herein do not necessarily state or reflect those of the United States government or any agency thereof.

This report is available at no cost from the National Renewable Energy Laboratory (NREL) at www.nrel.gov/publications.

Available electronically at SciTech Connect http:/www.osti.gov/scitech

Available for a processing fee to U.S. Department of Energy and its contractors, in paper, from:

U.S. Department of Energy

Office of Scientific and Technical Information

P.O. Box 62

Oak Ridge, TN 37831-0062

OSTI http://www.osti.gov

Phone: 865.576.8401

Fax: 865.576.5728

Email: reports@osti.gov

Available for sale to the public, in paper, from:

U.S. Department of Commerce

National Technical Information Service

5301 Shawnee Road

Alexandria, VA 22312

NTIS http://www.ntis.gov

Phone: 800.553 .6847 or 703.605 .6000

Fax: 703.605.6900

Email: orders@ntis.gov 


\section{ERRATA SHEET}

NREL REPORT/PROJECT NUMBER: NREL/TP-6A20-60360

DOE NUMBER: Contract No. DE-AC36-08GO28308

TITLE: Comparing Photovoltaic (PV) Costs and Deployment Drivers in the Japanese and U.S. Residential and Commercial Markets

AUTHOR(S): B. Friedman and R. Margolis (NREL) and J. Seel (LBNL)

ORIGINAL PUBLICATION DATE: February 2014, last revised June 2014

DATE OF CORRECTIONS: April 2016

The following corrections were made to this report:

p. 37, Figure 25 (not replaced)

The NPV values in the figure should be:

- $2700 \mathrm{kWh}: \mathrm{NPV}=\$ 3555$

- $3600 \mathrm{kWh}: \mathrm{NPV}=\$ 1892$

- $4500 \mathrm{kWh}: \mathrm{NPV}=\$ 825$

p. 38 , Figure 26 (not replaced)

The ROR values in the figure 25 should be:

- $\quad$ o $2700 \mathrm{kWh}: \mathrm{NPV}=15 \%$

- o $3600 \mathrm{kWh}: \mathrm{NPV}=8 \%$ (should be at center dashed line)

- o $4500 \mathrm{kWh}: \mathrm{NPV}=4 \%$

\section{p. 43 , second paragraph:}

- "Higher (and, in some cases, lower) household energy consumption, lower insolation, or a lack of excess-electricity payments in years 11-25 of the PV system's lifetime could result in a negative RoR for residential PV" was changed to "Lower insolation, or a lack of excess-electricity payments in years 11-25 of the PV system's lifetime could result in a negative RoR for residential PV.

pp. 50-51, Table B-1 (replaced)

Data in the table have been updated. 


\section{Acknowledgments}

The authors would like to thank the following individuals and organizations for their contributions to and review of this work. The authors would like to offer a special appreciation to the team from PHOTON Consulting, LLC, for its primary field research and analysis in Japan: Joe Lara, David Southwick, Nana Hori, Ravi Manghani, and Sherry Cheah. The authors are grateful for the participation of the many Japanese installation companies that participated in this research. The authors would also like to thank Ammar Qusaibaty and the U.S. Department of Energy Solar Energy Technologies Office Soft Cost Team for their sponsorship and review, Jarett Zuboy (consultant), Kristen Ardani, David Feldman, Billy Roberts, Jeffrey Logan, Ted James, and Margaret Mann (National Renewable Energy Laboratory), Ryan Wiser (Lawrence Berkeley National Laboratory), Izumi Kaizuka (RTS Corporation), and M.J. Shiao (GTM Research/Greentech Media). 


\section{List of Acronyms and Abbreviations}

$¥$

1H12, 1H13, etc. First half of 2012, first half of 2013, etc.

1Q13, 2Q13, etc. First quarter of 2013, second quarter of 2013, etc.

BNEF

EIA

FiT

FY

GW

HEM

ID

IEA

IRR

J-PEC

$\mathrm{kW}$

$\mathrm{kWh}$

METI

MW

NPV

NREL

PII

PV

RoR

TEPCO

$\mathrm{W}$
Bloomberg New Energy Finance

U.S. Energy Information Administration

Feed-in-tariff

Fiscal year

Gigawatt(s)

Home energy management system

Identification

International Energy Agency

Internal rate of return

Japan Photovoltaic Expansion Center

Kilowatt(s)

Kilowatt-hour(s)

Japanese Ministry of Economy, Trade, and Industry

Megawatt(s)

Net present value

National Renewable Energy Laboratory

Permitting, inspection, and interconnection

Photovoltaic(s)

Rate of return

Tokyo Electric Power Company

Watt(s) 


\section{Executive Summary}

Japan has reemerged in 2013 as one of the world's fastest-growing and largest photovoltaic (PV) markets (Renewable Energy World 2013). The annual growth rate in Japanese installed capacity during the first half of calendar year 2013 was about 270\%. Japan's PV market was on pace to triple in 2013 compared with 2012, with approximately $2.7 \mathrm{GW}$ installed during the first half of 2013 (compared to about 1.6 GW in the United States). This places Japan among the world's largest PV markets, along with China, Germany, and the United States.

This report explores details of the rapidly changing Japanese market as well as similarities and differences between the Japanese and U.S. markets. We collected data from a diverse group of Japanese PV installers, and we gathered additional Japanese and U.S. data from published sources as well as internal analyses. Specifically, we compare hardware costs, soft costs, and installed system prices for residential (less than $10 \mathrm{~kW}$ ) and small commercial (10-50 kW) PV systems in Japan and the United States. The analyzed soft costs include customer acquisition; installation labor; and permitting, inspection, and interconnection. In conjunction with these data, we analyze Japanese and U.S. policies and market characteristics to explore the factors that are driving PV economics and accelerating or impeding PV deployment in each country.

Our key findings are as follows:

Japanese PV system prices were $6 \%$ less than their U.S. counterparts in the residential $(\$ 4.64 / W$ versus $\$ 4.92 / W$ ) and $20 \%$ less in the small commercial $(\$ 3.59 / W$ versus $\$ 4.51 / W$ ) sectors in the first half of 2013. To explore this difference, we analyze PV hardware costs as well as a subset of soft costs in both countries. Japan's substantially higher module costs make its total hardware costs higher than U.S. costs: about $60 \%$ higher $(\$ 0.98 / \mathrm{W}$ difference) in the residential sector and $44 \%$ higher ( $\$ 0.67 / \mathrm{W}$ difference) in the small commercial sector (in the first half of 2013$).{ }^{1}$ The interplay between Japan's PV market and energy policies drives the country's PV economics and growth. Installed system price is a major aspect of this, and the increased sales volumes and competition stimulated by Japan's energy policies are among the many factors determining system price.

In part because of Japan's higher hardware costs, soft costs account for a significantly smaller proportion of system prices in Japan than in the United States (Figures ES-1 and ES-2). In the first half of 2013, soft costs accounted for 44\% of Japanese residential PV system prices versus $67 \%$ of U.S. prices, and they accounted for $39 \%$ of Japanese small commercial PV system prices versus $66 \%$ of U.S. prices.

\footnotetext{
${ }^{1}$ The reported system prices in this report were primarily derived from installer surveys. It is important to use caution when comparing prices across sources employing different methodologies or different time periods.
} 


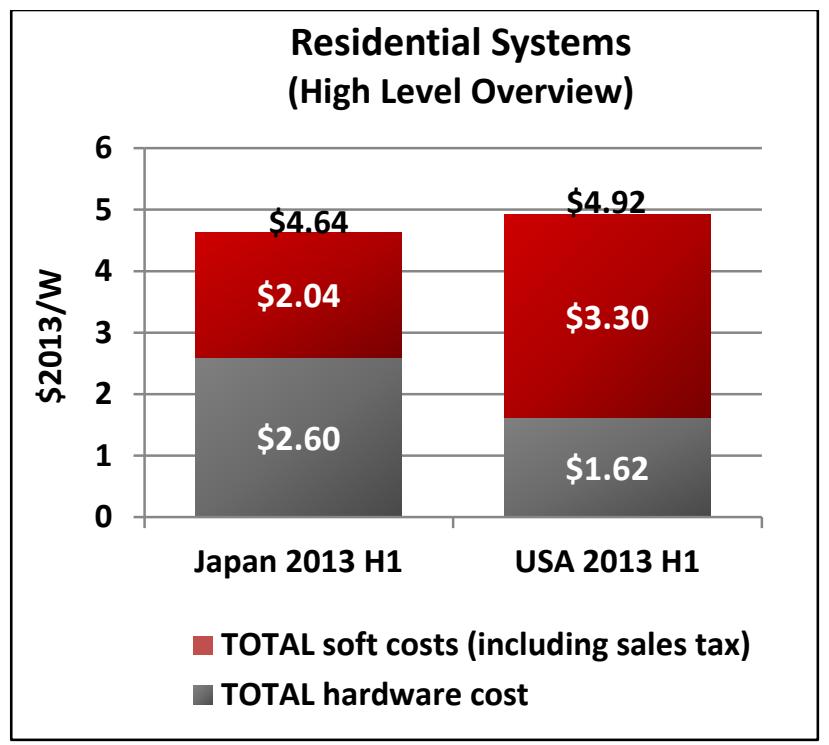

Figure ES-1. Japanese and U.S. residential PV hardware and soft costs, first half of $2013^{2}$

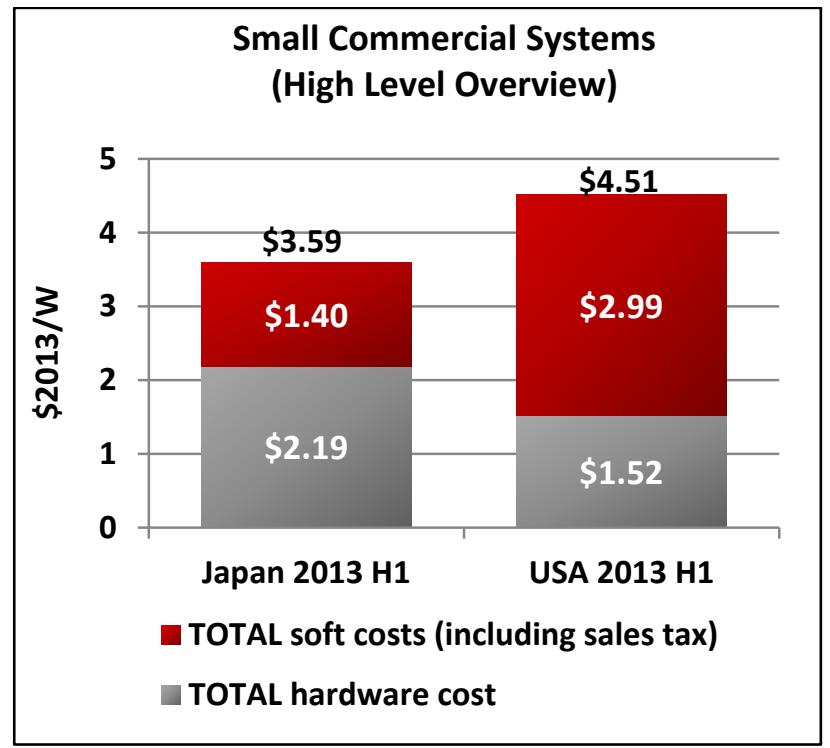

Figure ES-2. Japanese and U.S. small commercial PV hardware and soft costs, first half of 2013

Among the specific soft costs we examined, customer acquisition and system design account for the largest difference between Japanese and U.S. costs. Japanese costs in these two soft cost areas combined are approximately $50 \%$ lower $(\$ 0.23 / \mathrm{W}$ difference) in the residential sector. The difference is far more pronounced in the small commercial sector, where Japanese costs in the two categories combined are only $7 \%$ of those in the United States $\left(\$ 0.25 / \mathrm{W}\right.$ difference). ${ }^{3}$

\footnotetext{
${ }^{2}$ All prices are reported in U.S. dollars based on the average exchange rate of 95.46 Yen/\$ for H1 2013 (Federal Reserve 2013).

${ }^{3}$ We must compare Japanese soft costs in the first half of 2013 with U.S. soft costs in the first half of 2012 because of data availability, but this comparison is meaningful because total U.S. soft costs declined little between 2012 and 2013.
} 
Two of the key drivers of the Japanese market are the practice of cross-selling PV by companies already selling other products and services to prospective PV customers and the use of standardized PV system designs. These market characteristics increase the economic attractiveness of $P V$ and represent potential cost-reduction opportunities for U.S. companies and policymakers. In both the residential and commercial sectors, customer acquisition is eased by Japanese installers' preexisting relationships with non-PV customers. Japanese installers typically cross-sell PV to customers already purchasing other products and services from the installers' other business lines, such as appliances, home renovations, and even cars. Customeracquisition costs are also eased by the strong public support for PV in Japan following the Fukushima nuclear disaster of March 2011 as well as policy-driven improvements in project economics. Japan's residential system-design costs also are a fraction of U.S. costs because installers there use standardized design programs produced by major Japanese module manufacturers, resulting in typical residential design times of less than an hour.

The ability to combine the benefits of a number of policies - the feed-in-tariff(FiT), the national cash subsidy, and local incentives-has played an important role in making PV economically attractive to Japanese consumers. We modeled the economic return due to the FiT and national cash subsidy. We found that residential owners of 5-kW PV systems in our base case might expect an $8 \%$ rate of return (RoR) and a net present value (NPV) of $\$ 1,892$. These returns, however, are sensitive to a number of assumptions including insolation, post-FiT PV payments, system price, and energy consumption. Higher (and, in some cases, lower) household energy consumption, lower insolation, or a lack of excess-electricity payments in years 11-25 of the PV system's lifetime could result in a negative RoR for residential PV. Commercial PV, on the other hand, receives more generous terms than does residential PV under Japan's FiT (as does utilityscale solar, referred to in Japan as "mega" solar), and our modeled commercial returns are highly favorable under a range of assumptions: our base case has an NPV of $\$ 129,103$ and an RoR of $74 \%$, and these never drop below about $\$ 100,000$ and $48 \%$ under the assumptions we modeled.

The differential FiT returns among sectors are shifting Japanese PV deployment toward commercial and mega solar systems. This is an intentional policy shift, based on the government's renewable energy capacity-addition targets as well as the Japanese market's ability to deploy low-cost hardware in non-residential sectors. Commercial market growth-which seems to have been slowed somewhat by issues such as labor shortages and land-acquisition and interconnection problems - likely will be strong for 2013-2015 as these issues are addressed. Our discussions with Japanese installers and other market stakeholders suggest that the Japanese PV market will slow to a stable average annual market of about $2.5-3.5 \mathrm{GW}$ by 2016. 


\section{Table of Contents}

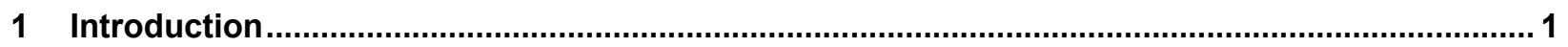

2 PV Data Collection Methods and Sample Characteristics ........................................................ 3

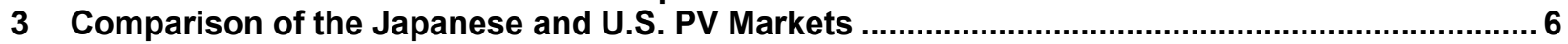

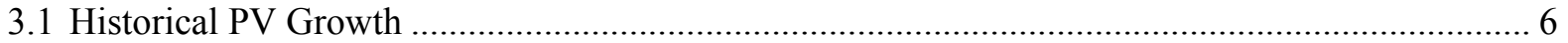

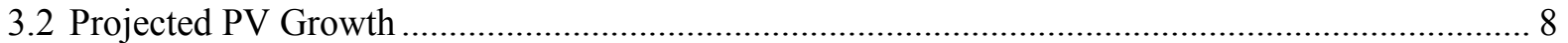

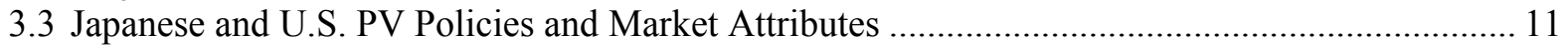

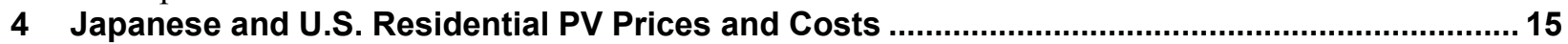

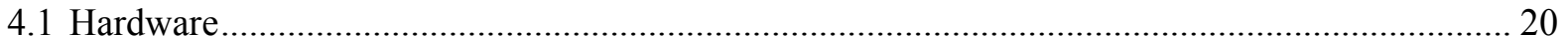

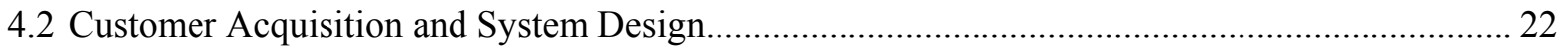

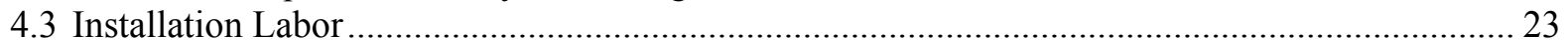

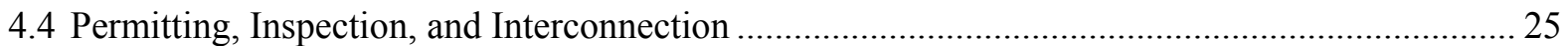

5 Japanese and U.S. Small Commercial (10-50 kW) PV Prices and Costs ................................... 27

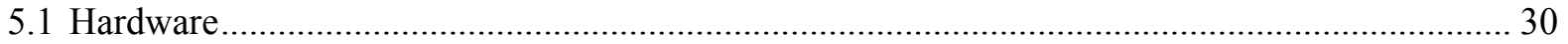

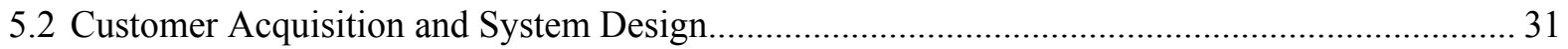

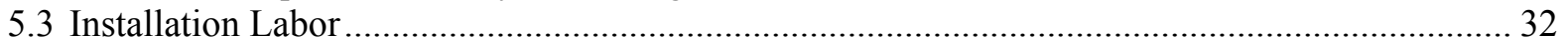

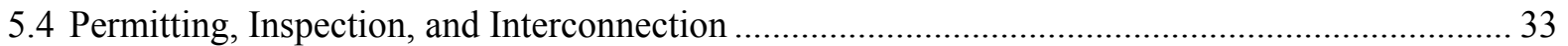

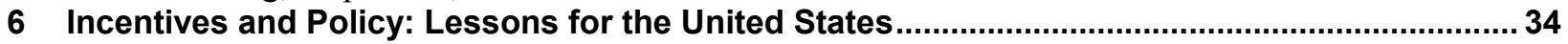

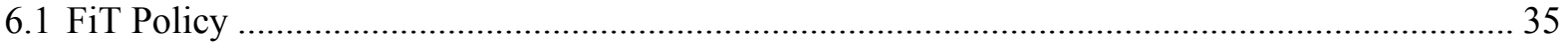

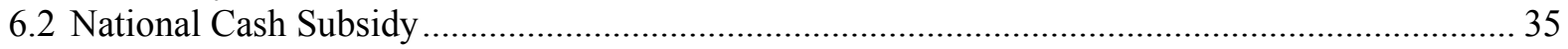

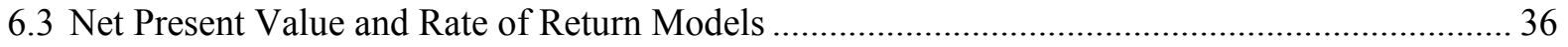

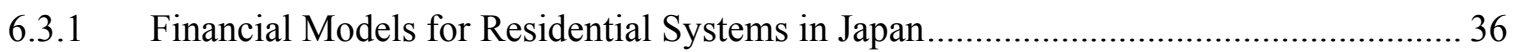

6.3.2 Financial Models for Commercial Systems in Japan ................................................. 38

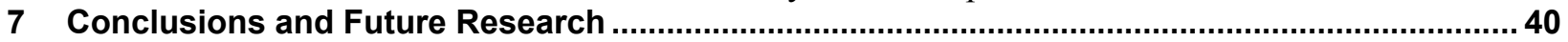

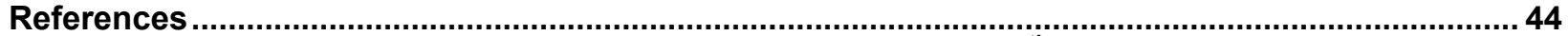

Appendix A. Japanese PV Prices and Costs-Top and Bottom $10^{\text {th }}$ Percentile, with Capacity-

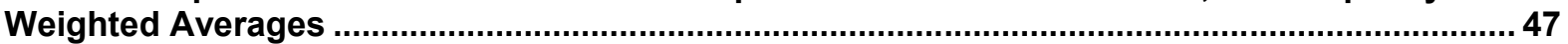

Appendix B. Modeled PV Economic-Return Scenarios ............................................................. 48

Appendix C. PV System Costs by Business Model and Location ...................................................5 53

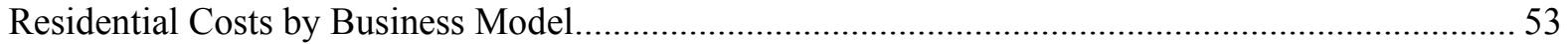

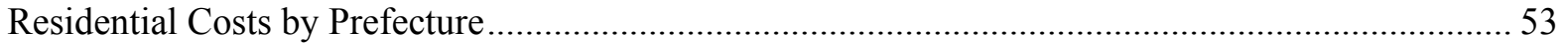

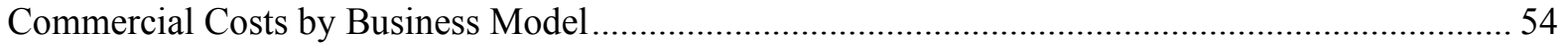

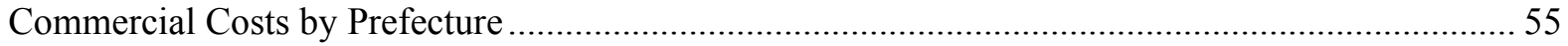

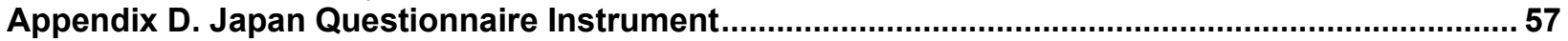

Number of PV Systems Installed and Cost Breakdown (Questions 1 through 3) .............................. 57

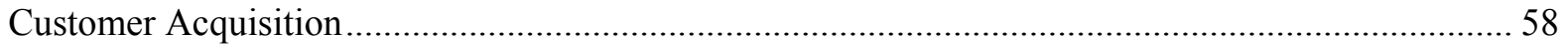

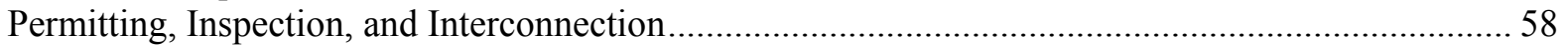

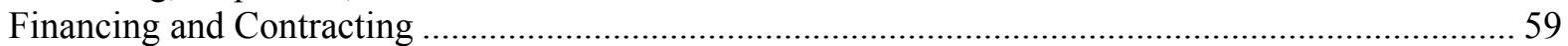

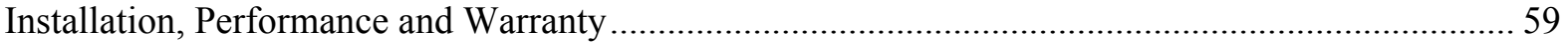




\section{List of Figures}

Figure ES-1. Japanese and U.S. residential PV hardware and soft costs, first half of 2013.............. vi

Figure ES-2. Japanese and U.S. small commercial PV hardware and soft costs, first half of 2013

Figure 1. Map of Japan with prefectures included in this study highlighted in yellow

Figure 2. Japanese and U.S. annual PV capacity additions, all sectors, 2002-1H13 ........................ 7

Figure 3. Capacity share of residential PV installations, United States versus Japan, 2009-1H13

Figure 4. Japanese electricity resource mix and projections ..................................................... 9

Figure 5. Capacity of PV systems approved for FiT in Japan by METI (384,390 systems) and installed (193,343 systems), July 2012-February 2013

Figure 6. Comparison of Japanese and U.S. solar resource, with some similarity between Japan's solar resource and that of the northeastern United States ...........................................12

Figure 7. Structural distinctions between Japanese and U.S. PV markets................................... 13

Figure 8. Median installed system prices for residential PV Systems of $10 \mathrm{~kW}$ or less, United States versus Japan, 2001-1H13

Figure 9. Components of Japanese residential PV system price in $1 \mathrm{H} 13$....................................... 17

Figure 10. Price differences between U.S. (1H12) and Japanese (1H13) residential systems.......... 18

Figure 11. Comparison of total residential PV system hardware and soft costs among Japan (1H13), the United States in 1H12, and the United States in 1H13, showing that most of the decline in U.S. system price between 2012 and 2013 was due to hardware cost reductions

Figure 12. Japanese (capacity-weighted average) and U.S. residential PV hardware costs, $1 \mathrm{H} 13$.

Figure 13. Shares of foreign and domestic module shipments in Japan, 2Q12-2Q13...

Figure 14. Japanese (1H13) and U.S. (1H12) residential PV customer-acquisition and system-

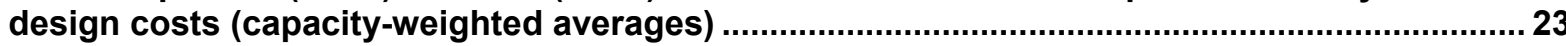

Figure 15. Japanese (1H13) and U.S. (1H13) residential PV installation-labor costs and time requirements.

Figure 16. Japanese (1H13) and U.S. (1H12) mechanical and electrical mean labor wage rates ..... 25

Figure 17. Japanese (1H13) and U.S. (1H12) residential PV PII costs and time requirements ......... 26

Figure 18. Components of Japanese small commercial (10-50 kW) PV system price in 1H13........ 28

Figure 19. Price differences between U.S. (1H12) and Japanese (1H13) commercial systems........ 29

Figure 20. Comparison of total commercial PV system hardware and soft costs among Japan (1H13), the United States in 1H12, and the United States in 1H13, showing that most of the decline in U.S. system price between 2012 and 2013 was due to hardware cost reductions .... 30

Figure 21. Japanese (capacity-weighted average, 1H13) and U.S. (1H12) commercial PV hardware

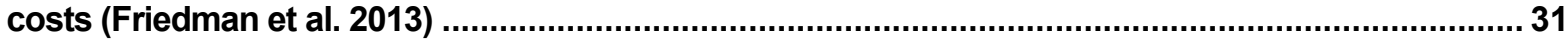

Figure 22. Japanese (1H13) and U.S. (1H12) commercial PV customer-acquisition and systemdesign costs (capacity-weighted averages) .................................................................................... 32

Figure 23. Japanese (1H13) and U.S. (1H12) commercial PV installation-labor costs and time

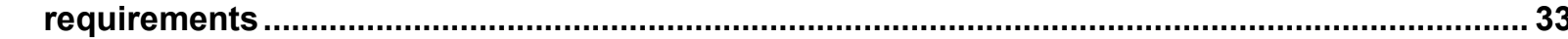

Figure 24. Japanese (1H13) and U.S. (1H12) commercial PV PII costs and time requirements ....... 34

Figure 25. Sensitivity of modeled Japanese residential PV system NPV to changes in

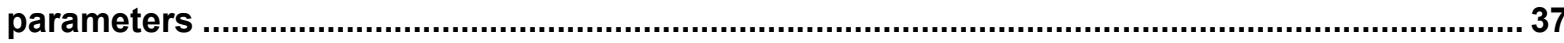

Figure 26. Sensitivity of modeled Japanese residential PV system RoR to changes in parameters

igure 27. Sensitivity of modeled Japanese commercial PV system NPV to changes in

parameters ..................................................................................................

parameters

Figure 29. Japanese (1H13) and U.S. (1H12) PV non-hardware costs analyzed in this report: residential (left) and small commercial (right)...

igure $\mathrm{C}-1$. Japanese residential PV costs by business model....

Figure C-2. Japanese residential PV costs by prefecture for the eight prefectures studied 
Figure C-3. Japanese commercial PV costs by business model .................................................. 55 Figure C-4. Japanese commercial PV costs by prefecture for the eight prefectures studied .......... 56

\section{List of Tables}

Table 1. Price and Cost Breakdown Definitions Used in Data Collection ......................................... 5

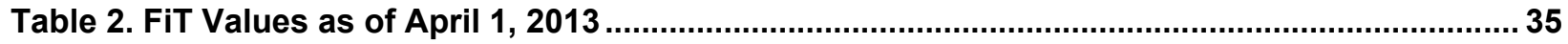

Table A-1. Soft Costs, Hardware Costs, and Other Costs for Japanese Residential PV, 1H13 ........ 47

Table A-2. Soft Costs, Hardware Costs, and Other Costs for Japanese Small Commercial

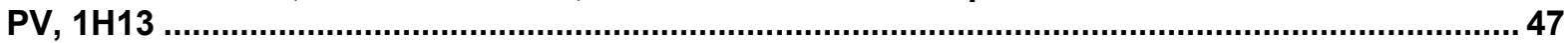

Table B-1. Scenarios for Japanese Residential PV Economic Returns ..........................................50

Table B-2. Scenarios for Japanese Commercial PV Economic Returns .........................................52

Table B-3. Assumptions in Economic Modeling of Japanese PV Systems ...................................... 52 


\section{Introduction}

The Japanese photovoltaic (PV) market in all customer segments is expanding rapidly, outpacing the U.S. market despite Japanese land constraints and relatively low insolation. In the first 8 months of the Japanese fiscal year-April to November 2013-Japan installed approximately 4.6 GW of new PV capacity, of which $3.6 \mathrm{GW}$ were utility and commercial installations and approximately $950 \mathrm{MW}$ were household installations (Tsagas 2014). These data indicate a marked sectoral migration towards non-residential markets and — on a percentage basis - away from the residential installations that have dominated the Japanese PV market throughout its history. The challenges and successes related to Japan's rapid PV growth can inform stakeholders working to strengthen the U.S. PV market.

The Fukushima nuclear disaster of March 2011 — and the subsequent shutdown of nearly all Japanese nuclear plants - has helped catalyze recent Japanese PV market growth. The most important policy spurring this growth is the feed-in-tariff (FiT), which became effective July 1, 2012. ${ }^{4}$ The FiT requires utilities to allow grid connections for $\mathrm{PV}$ and execute contracts required for purchase of the solar electricity and other forms of renewable energy. Despite bottlenecks in installing PV approved under the FiT, annual additions are likely to be in the range of 5-7 GW through 2015.

In addition to the FiT, various other market and policy attributes are shaping Japanese PV growth. Japan has implemented a more managed, centralized policy strategy with closer cooperation among government, utilities, and industry compared with the United States. To this end, on April 11, 2014, the Japanese Cabinet approved a new "Energy Basic Plan," the first of its kind since June 2010. The plan does not provide specific energy resource targets; rather, it builds upon measures already underway or previously proposed. It specifies nuclear and coal-based energy as important sources of electricity for the future, consistent with the government's concerns about higher electricity prices. The plan also calls for increasing the share of renewables in the electricity generation mix, compared to prior targets $-13.5 \%$ by 2020 and $20 \%$ by 2030 , including hydroelectric generation (Nobuoka 2014).

A core difference between the two countries is the utility structure and diversity, with only 10 utilities in Japan compared with more than 3,000 in the United States that include investorowned and public entities. Unlike the United States, Japan also has used policy effectively to tie energy efficiency to PV and as a lever to reduce PV system prices. The national government offers a cash subsidy for PV system purchases, and more than 900 local incentive programs (e.g., cash rebates, low-cost loans, and tax incentives) are available. There are no penalties for combining local and national incentives, and the FiT may be combined with the national cash subsidy for small systems (James et al. 2014).

The structures of distributed PV markets in Japan and the United States also differ. The Japanese residential market relies on a complex supplier/installer network that includes solar and various non-solar businesses and is controlled primarily by major domestic manufacturers. Compared with the United States, this system adds various mark-ups that increase the retail price of PV

\footnotetext{
${ }^{4}$ However, the FiT law was actually approved by the Cabinet of Japan prior to the earthquake, on the morning of March 11, which was the day of the earthquake. The policy was approved by the Democratic Party of Japan, in power at the time.
} 
equipment. The Japanese market also operates within a unique culture of relationships, trust, and loyalty. Japanese installers and module manufacturers maintain relationships through various solar and non-solar business activities, and PV consumers are willing to pay a premium to work with installers and products they know and trust from previous relationships.

We found that Japan's substantially higher module costs lead to total hardware costs that exceed U.S. costs: about $\$ 0.98 / \mathrm{W}$ higher in the residential sector and $\$ 0.67 / \mathrm{W}$ higher in the small commercial sector in the first half of calendar year 2013 (1H13). In particular, Japanese module prices are higher because of the consumer and installer preference for relatively expensive domestic brands and the complex module distribution network that incurs additional supplychain costs. The entrance of cheaper foreign modules - as well as pure-play PV installers choosing the lowest-cost options-likely will push Japanese module costs downward.

The residential soft costs analyzed in this report via survey responses total \$0.98/W for Japan compared with $\$ 1.14 / \mathrm{W}$ for the United States. The soft costs analyzed in the report for the small commercial sector total $\$ 0.29 / \mathrm{W}$ for Japan, compared with $\$ 0.82 / \mathrm{W}$ for the United States. In each case these costs constitute only part of overall soft costs. For the residential sector, other soft costs amount to $\$ 1.05 / \mathrm{W}$ for Japan and $\$ 2.22 / \mathrm{W}$ for the United States. For the small commercial sector, they amount to $\$ 1.12 / \mathrm{W}$ for Japan and $\$ 2.25 / \mathrm{W}$ for the United States. Because of the lack of available primary research on 2013 U.S. soft costs, we instead compare 1H13 Japanese soft costs with 1H12 U.S. soft costs in multiple instances throughout the report. Despite the different study periods, we make this comparison because the decline in total U.S. installed prices between 2012 and 2013 is roughly equivalent to the decline in hardware costs during this period, indicating that total U.S. soft costs did not decline significantly between 2012 and 2013.

Among the specific soft costs we examined, customer acquisition and system design account for the largest difference between Japanese and U.S. costs. Japanese costs are $\$ 0.23 / \mathrm{W}$ lower in the residential sector and $\$ 0.25 / \mathrm{W}$ lower in the small commercial sector. In both sectors, customer acquisition is eased by Japanese installers' preexisting relationships with non-PV customers and the public support for renewable energy following Fukushima. Japan's system-design costs also are a fraction of U.S. costs because installers there use standardized design programs produced by major Japanese module manufacturers, resulting in typical residential design times of less than an hour. Cross-selling of PV within non-PV industries, increasing the economic attractiveness of PV, and standardizing the PV system-design process all represent potential costreduction opportunities for U.S. companies and policymakers.

Comparative PV installation-labor costs tell an ambiguous story. Japan's use of turnkey PV kits - which are much more prevalent there than in the United States - should cut installationlabor times and costs. In the residential sector, however, Japanese installation-labor costs are \$0.17/W higher than U.S. costs (comparing 1H13 Japanese costs with 1H13 U.S. costs). The reasons for this are not entirely clear. Differences in the countries' typical residential roofing materials play a role, as do different allocations of mechanical and electrical labor in each country. Even if ultimately deemed less cost effective for residential installations, it is unlikely that the prevalence of kits in the Japanese market will change, in part because of the influence large PV kit manufacturers have in the market. In the commercial sector, the cost differential is more intuitive, with Japan apparently reaping the benefits of the kits (along with lower 
mechanical and electrical wage rates in the commercial sector) for a $\$ 0.20 / \mathrm{W}$ cost advantage. Japan's lower incidence of suburban sprawl might also reduce installation-labor costs (in both the residential and commercial sectors) owing to shorter commute times.

Finally, Japanese permitting, inspection, and interconnection (PII) costs are $\$ 0.10 / \mathrm{W}$ lower in the residential sector and $\$ 0.09 / \mathrm{W}$ lower in the commercial sector. Unlike U.S. installers, Japanese installers incur negligible permitting fees, permitting preparation and submission costs, and inspection costs. Installers and policymakers in the United States might see Japan's streamlined regulatory processes - as well as the high level of standardization and quality control that make them possible — as additional cost-reduction opportunities.

The remainder of the report is structured as follows. Section 2 describes our PV data collection methods and sample characteristics. Section 3 compares the Japanese and U.S. PV markets. Section 4 analyzes Japanese and U.S. residential PV prices and costs, and Section 5 does the same for commercial PV. Section 6 models the economic benefits of Japanese national PV policies. Section 7 provides conclusions.

\section{PV Data Collection Methods and Sample Characteristics}

Our primary research relied on interviewing a diverse set of Japanese installers about PV hardware and soft costs in the residential (less than $10 \mathrm{~kW}$ ) and small commercial (primarily 10$50 \mathrm{~kW}$ ) markets. ${ }^{5}$ From May to October 2013, the National Renewable Energy Laboratory (NREL) and PHOTON Consulting conducted 104 interviews (of about 20-30 minutes each) with 81 installers in Japan; several installers completed two interviews, one related to residential PV efforts and the other to commercial PV efforts. In all, there were 73 residential responses and 31 small commercial responses. We based the interviews on a questionnaire (Appendix D) similar to one used in NREL's recent U.S. soft cost benchmarking study (Friedman et al. 2013). Whereas the U.S. questionnaire focused on installations in $1 \mathrm{H} 12$, the Japan questionnaire focused on 1H13. Table 1 shows definitions used in the data collection. In general, the analysis was based on a capacity-weighted average approach, as opposed to a simple average approach. Capacity-weighted averages weight installer responses based on how much PV they installed during the study period.

Although not intended to represent a statistically valid sample of the Japanese market at high confidence levels, the sample of 81 installers constitutes more than $15 \%$ of the approximately 500 total installers working in our eight prefectures of interest. These prefectures include Nagano, Shizuoka, Kyoto, Osaka, Shiga, and the greater Tokyo area encompassing Tokyo, Chiba, and Saitama (Figure 1).

Japanese PV installers often engage in multiple business activities aimed at capturing more of the customer dollar and building the customer relationship, ranging from new home building (the most common non-solar activity among installers) to home remodeling, electrical services,

\footnotetext{
${ }^{5}$ Unlike the U.S. installers from whom we collected data in previous efforts, the Japanese installers were reluctant to provide information via e-mail or web surveys, thus we relied almost exclusively on in-person interviews. All but one commercial installation was within the range of $10-50 \mathrm{~kW}$ in average system size. That one installer's average system size was significantly larger.
} 
appliance sales, and even car sales and other disparate activities. We captured this diversity of business approaches by including installers ranging from those exclusively engaged in solar installation to those for whom solar activity is a small portion of overall business. For 53 of the completed interviews, solar installations constituted less than one third of respondents' business activity. For 31 interviews, solar installations constituted one third to two thirds of business activity. For the remaining 20 interviews, solar installations constituted more than two thirds of business activity.

The system prices in this report were primarily derived from primary research via a survey of installers. In a rapidly changing industry, like the global PV industry, it is important to use caution when comparing prices across sources employing different methodologies or different time periods. In theory reported PV system prices should be similar to modeled bottom-up system prices for a given period. However, in practice a number of factors can produce different estimates. Market factors, time lags, scope (geographic, technological, average system size), and financing can all have significant impacts on how prices are reported in specific reports (Feldman et al. 2012). 
Table 1. Price and Cost Breakdown Definitions Used in Data Collection

\begin{tabular}{|c|c|c|}
\hline Category & Component & Definition \\
\hline \multirow{6}{*}{$\begin{array}{l}\text { a. Hardware } \\
\text { costs }\end{array}$} & Module & Module cost \\
\hline & Inverter & Inverter, inverter pad \\
\hline & Racking & $\begin{array}{l}\text { Racking, mounting system, foundation (ballast, } \\
\text { driver pile, tracker) }\end{array}$ \\
\hline & Wiring, cables & Wiring, cables, conduit \\
\hline & Monitor & Monitoring system \\
\hline & Other & $\begin{array}{l}\text { Miscellaneous equipment components, such } \\
\text { as flashings and supports, charge controllers, } \\
\text { weeb lugs, and other similar items. }\end{array}$ \\
\hline \multirow[t]{10}{*}{ b. Soft cost } & $\begin{array}{l}\text { Customer } \\
\text { acquisition }\end{array}$ & $\begin{array}{l}\text { Sales and marketing direct costs (not including } \\
\text { overhead) }\end{array}$ \\
\hline & $\begin{array}{l}\text { System design and } \\
\text { procurement }\end{array}$ & $\begin{array}{l}\text { System-design, price quotation, and } \\
\text { procurement costs }\end{array}$ \\
\hline & Subsidies & $\begin{array}{l}\text { Application for national, prefectural, and local } \\
\text { municipal subsidies }\end{array}$ \\
\hline & Permitting & Application for permitting with utility provider \\
\hline & $\begin{array}{l}\text { Financing and } \\
\text { contract }\end{array}$ & Financing and signing contract \\
\hline & $\begin{array}{l}\text { Mechanical } \\
\text { installation }\end{array}$ & $\begin{array}{l}\text { Installation labor for module, foundation, } \\
\text { racking, and scaffolding cost }\end{array}$ \\
\hline & $\begin{array}{l}\text { Electrical } \\
\text { installation }\end{array}$ & $\begin{array}{l}\text { Installation labor for inverter station(s), } \\
\text { electrical connection }\end{array}$ \\
\hline & Inspection & Inspection fees \\
\hline & Interconnection & $\begin{array}{l}\text { Interconnection process, transformer, } \\
\text { substation, transmission, and being on site } \\
\text { during utility's inspection }\end{array}$ \\
\hline & $\begin{array}{l}\text { Performance and } \\
\text { warranty }\end{array}$ & $\begin{array}{l}\text { Post-installation performance inspections and } \\
\text { warranty application }\end{array}$ \\
\hline $\begin{array}{l}\text { c. Operating } \\
\text { profit margin }\end{array}$ & $\begin{array}{l}\text { Operating profit } \\
\text { margin }\end{array}$ & Installer's operating profit margin \\
\hline $\begin{array}{l}\text { Total system } \\
\text { price }\end{array}$ & Total system price & Total installed price paid by the end customer \\
\hline
\end{tabular}




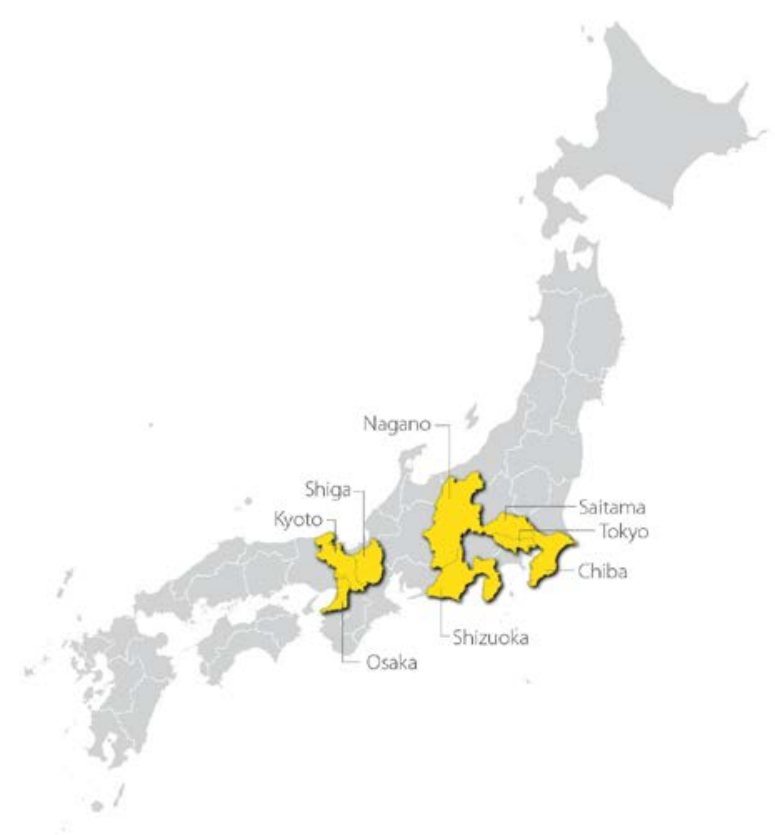

Figure 1. Map of Japan with prefectures included in this study highlighted in yellow

\section{Comparison of the Japanese and U.S. PV Markets}

This section compares the Japanese and U.S. PV markets, including historical and projected PV growth as well as PV policies and market attributes. Japan has emerged in 2013 as one of the world's two fastest-growing PV markets in all major customer segments, along with China. This rapid growth has been accompanied by major changes in policy and market characteristics, which appear poised to drive substantial PV deployment in the coming years. The U.S. PV market - which has similarities with the Japanese market but also differences - is projected to grow rapidly as well.

\subsection{Historical PV Growth}

With annual installations rising from about $1.7 \mathrm{GW}$ in 2012 to $2.7 \mathrm{GW}$ for just the first half of 2013, compared with 1.6 GW in the United States in the same period, Japan's growth pace for the first half of 2013 significantly exceeds that of prior years (Figure 2). Some experts place the size of Japan's PV market at a close second behind China for 2013 (Wile 2013). As of November 2013, Japan has installed approximately $11.9 \mathrm{GW}$ of cumulative PV capacity (Tsagas 2014), making it the most deployed renewable energy technology in the country.

The Fukushima nuclear disaster of March 2011 has been the primary catalyst for Japan's recent PV growth. The disaster spurred a new national energy strategy aimed at compensating for the 
shutdown of nearly all of Japan's nuclear reactors, which had previously generated approximately $30 \%$ of the nation's electricity (Burger 2012). The policy centerpiece of this strategy is the "Act on Purchase of Renewable Energy Sourced Electricity by Electric Utilities," more commonly known as the FiT policy. The FiT became effective July 1, 2012, was revised down for projects installed on or after April 1, 2013 - which stimulated a rush of PV installations in the first quarter of 2013 (1Q13) - and is set for annual revisions on this date moving forward. METI sets the FiT tariff and requires utilities to allow grid connections for PV and to execute contracts required for purchase of the solar and other forms of renewable energy.

Unlike the U.S. market, the recent Japanese PV market was dominated by residential installations until 2013 (Figure 3). As recently as the start of 3Q12, the Japanese residential market dominated both in capacity (66\%) and in number of systems (94\%). The FiT changed this significantly. Residential systems represent only about $10 \%$ of the capacity share among approved FiT applications, although they maintain a $74 \%$ share of the number of systems (Yamaya et al. 2013). Non-residential Japanese PV sectors (commercial and mega solar) only began significant growth after passage of the FiT. For the purposes of this report, we define commercial installations as $10-50 \mathrm{~kW}$ in size and mega solar as any ground-mounted installation greater than $1 \mathrm{MW}$ in size.

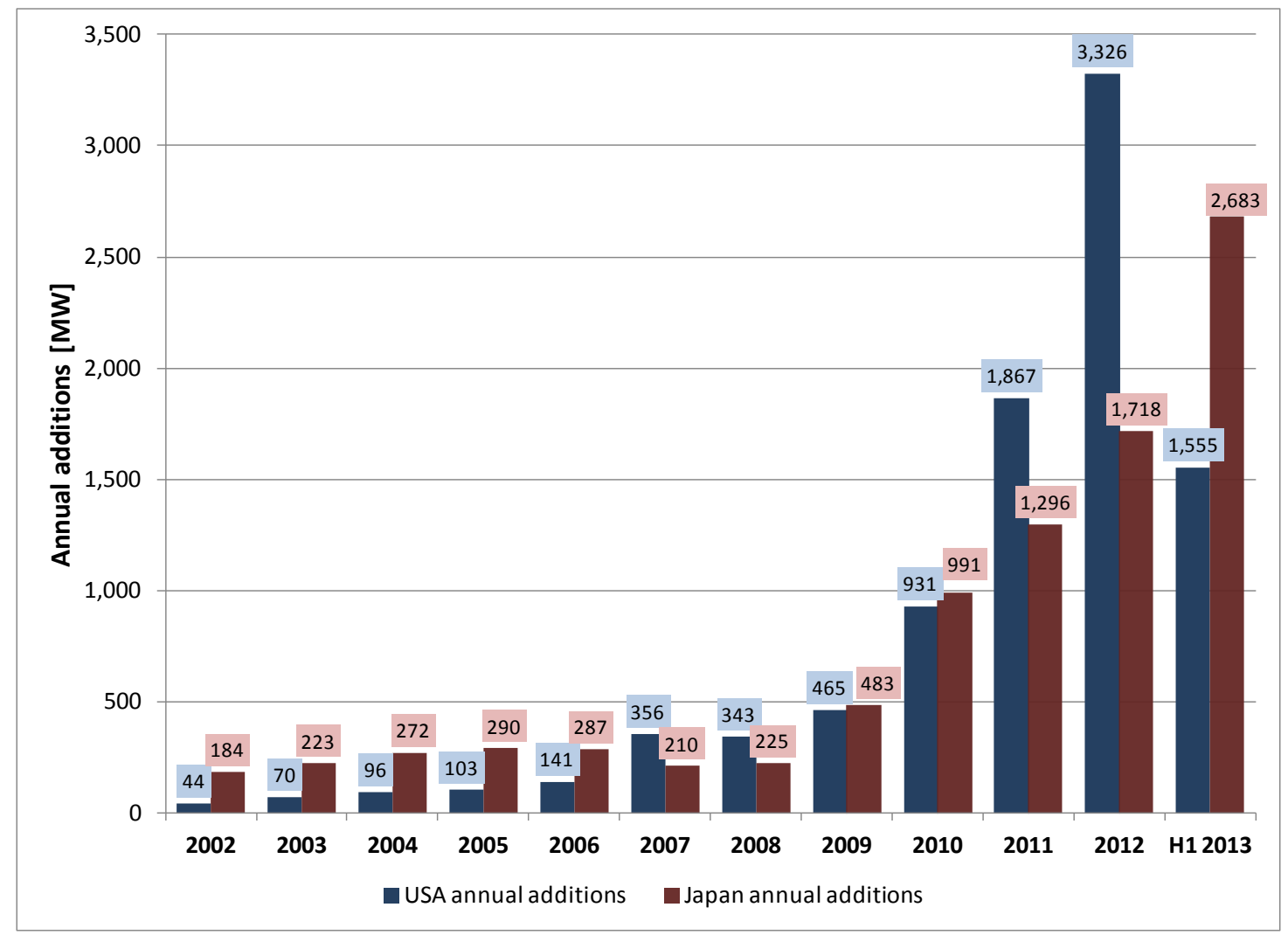

Figure 2. Japanese and U.S. annual PV capacity additions, all sectors, 2002-1H13

Sources: METI (2013), Yamada et. al. (2013), GTM/SEIA (2013), Sherwood (2013) 


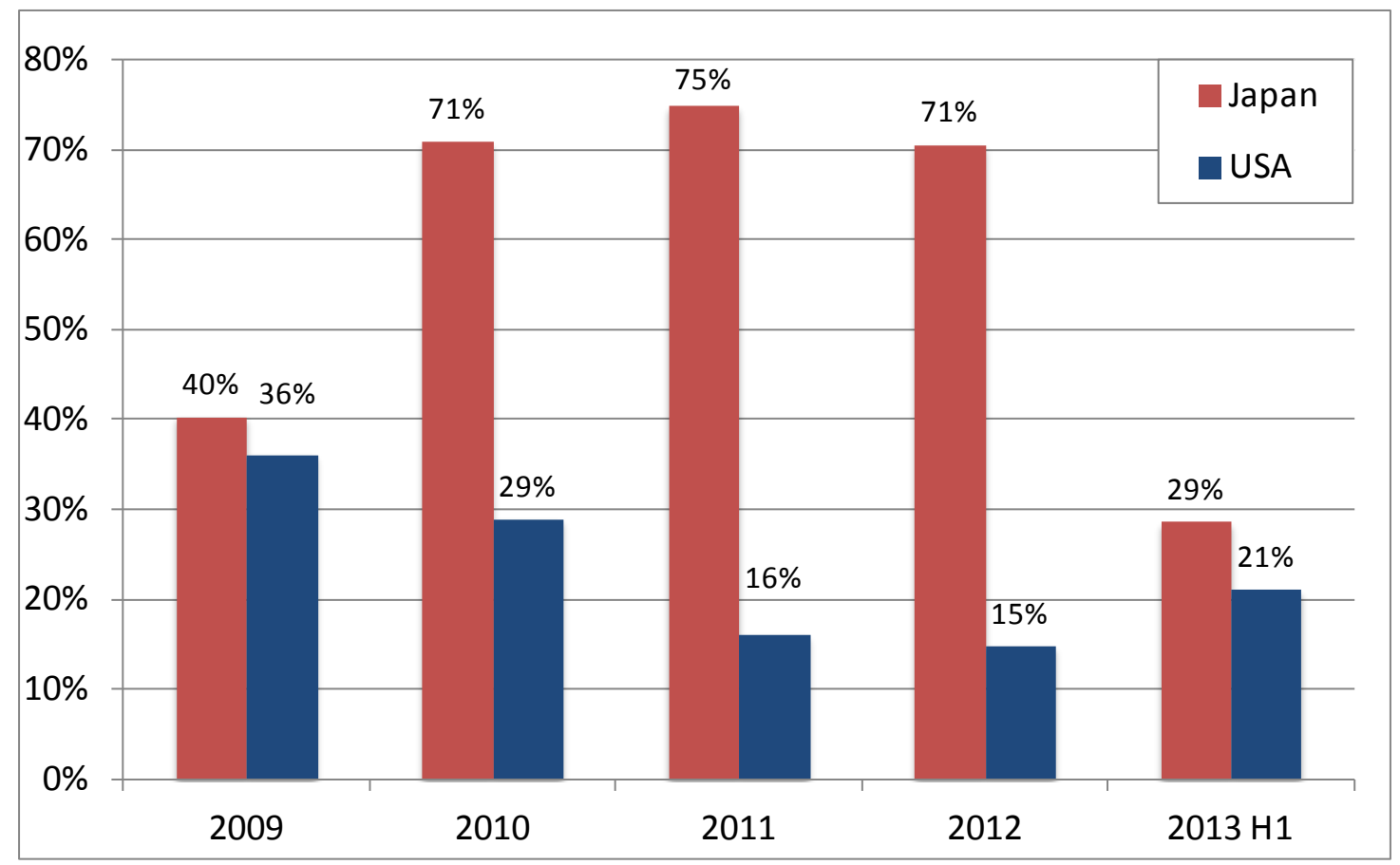

Figure 3. Capacity share of residential PV installations, United States versus Japan, 2009-1H13

Source: METI (2013), GTM/SEIA (2013)

\subsection{Projected PV Growth}

The longevity of Japan's PV boom and the long-term evolution of its electricity sector are uncertain. Japan's electricity-generation mix changed quickly after Fukushima (Figure 4). Although there is broad agreement that the solar market will continue to grow in 2013-2014, long-term growth is unpredictable and depends in part on the potential resurgence of nuclear energy. Our conversations with Japanese PV installers revealed a widespread belief that the current government will reintroduce nuclear energy but uncertainty about the timing and extent of any potential comeback. The U.S. Energy Information Administration estimates that Japan's nuclear generation will attain about two-thirds of its pre-Fukushima level by 2020 (Figure 4). Owing to high government debt and the possible nuclear resurgence, the government might also accelerate expected PV FiT rate cuts, thus dampening PV internal rates-of-return (IRRs). However, Japan's near- and long-term overall energy-capacity shortfalls suggest that the national government might maintain some form of the "all of the above" strategy adopted after Fukushima, with its emphasis on renewables and energy efficiency. Our discussions with Japanese installers and other market stakeholders suggest that the current growth trajectory will likely slow to a stable average annual market of about 2.5-3.5 GW of PV by 2016. 


\section{Electricity Generation in Japan}

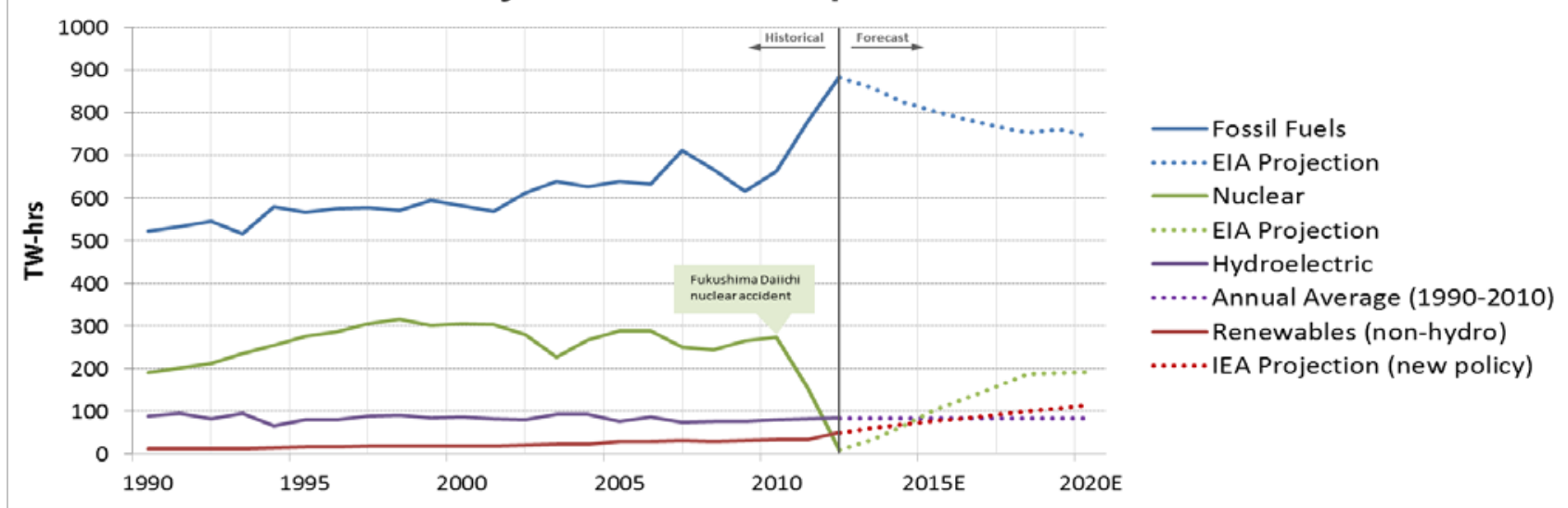

Figure 4. Japanese electricity resource mix and projections

Source: James et al. (2014)

As a portion of the global market, it is anticipated that both Japan and the U.S. will roughly maintain their current market share through 2016, with Japan expected to continue to be the larger market. For the period, Japan and the U.S. are expected to maintain their current global market share of 18-20\% and Japan 12-15\% respectively (Chase 2014, BNEF 2014, Shah 2014, Lee 2014, Osborne 2014). Increased solar investments have accompanied Japan's new energy strategy, and this is enhancing solar growth. In terms of PV revenue, Japan could overtake Germany as the world's largest PV market in calendar year 2013, potentially reaching an installation level valued at $\$ 20-\$ 25$ billion. ${ }^{6}$ This would be double Japan's $\$ 11$ billion market in 2012 (PHOTON Consulting 2013, Hill 2013, Solar Daily 2013) and would place Japan's share of global PV system revenue at 24\% in 2013, compared with 14\% in 2012 and $9 \%$ in 2011 (Renewable Energy World 2013). Japan's biggest banks-Mitsubishi UFJ Financial Group Inc., Mizuho Financial Group Inc., and Sumitomo Mitsui Financial Group Inc.- expect the domestic solar market's growth to stabilize and sustain a level of as much as \$19 billion per year through 2015 (Watanabe 2013).

Several other factors contribute to the growth of PV in Japan. METI offers low-interest loans to rooftop solar installers to boost local markets (Meza 2013). Residential project returns also benefit from residential electricity prices in Japan that are $20 \%-30 \%$ higher than the Organization for Economic Cooperation and Development (OECD) average (Burger 2012). ${ }^{7}$ The cost of capital in Japan is also extremely low; a 10-year government bond yields approximately 0.7\%, further enhancing PV economics for investors (PHOTON Consulting 2013).

The FiT created an immediate surge in PV applications to METI. PV capacity approved for the FiT by METI spiked from about 500 MW in July 2012 (the month the FiT took effect) to 5.6 GW in February 2013 (Yamaya et al. 2013). At the same time, Japanese capacity additions lagged behind both approved projects and shipments, particularly for systems of $400 \mathrm{~kW}$ or greater. Due to the rate at which METI approvals were outpacing actual installations, METI

\footnotetext{
${ }^{6}$ With revenue defined as megawatts installed multiplied by dollars per watt.

${ }^{7}$ Tokyo Electric Power Company (TEPCO) published electricity prices for 2013 at $\$ 0.19 / \mathrm{kWh}$ to $\$ 0.29 / \mathrm{kWh}$ in the

Tokyo region. Prices elsewhere in the country are comparable.
} 
announced in October 2013 that it is considering cancelling or encouraging cancellation of some previously approved FiT projects pending an investigation into the inventory buildup (PV-Tech 2013). The investigation focuses on potential abuses for projects greater than $400 \mathrm{~kW}$. Figure 5 shows PV capacity approved by METI under the FiT policy versus installations by market segment. About 10 times more capacity was approved than was installed during this period, with the most dramatic disparity in the mega solar segment. This indicates the magnitude of uncertainty inherent in market forecasts as well as the difficulty of modeling utility and other regulatory constraints.

In addition to the expected time between a project's approval and its installation, our discussions with market participants revealed several reasons for the large lag between PV approval/shipment and installation, including grid-connection and land-acquisition problems. Delays in interconnection approvals typically range from about 4-12 months. As the prefecture with the most available land for solar farms, Hokkaido has experienced the largest disparity between approved and installed capacity. Although it received approval for several gigawatts of mega solar under the FiT, Hokkaido has been unable to connect more than about one in four approved projects to the grid due to connection problems and oversupply. Hokkaido Electric Power Company announced in August 2013 that it will not be able to accommodate more than $400 \mathrm{MW}$ of utility-scale solar-powered generating capacity (projects of $2 \mathrm{MW}$ or more) due to limited hosting capacity (O’Rorke 2013). ${ }^{8}$ In some cases, installers could be delaying installations to capitalize on rapidly falling hardware prices, which could increase operating margins.

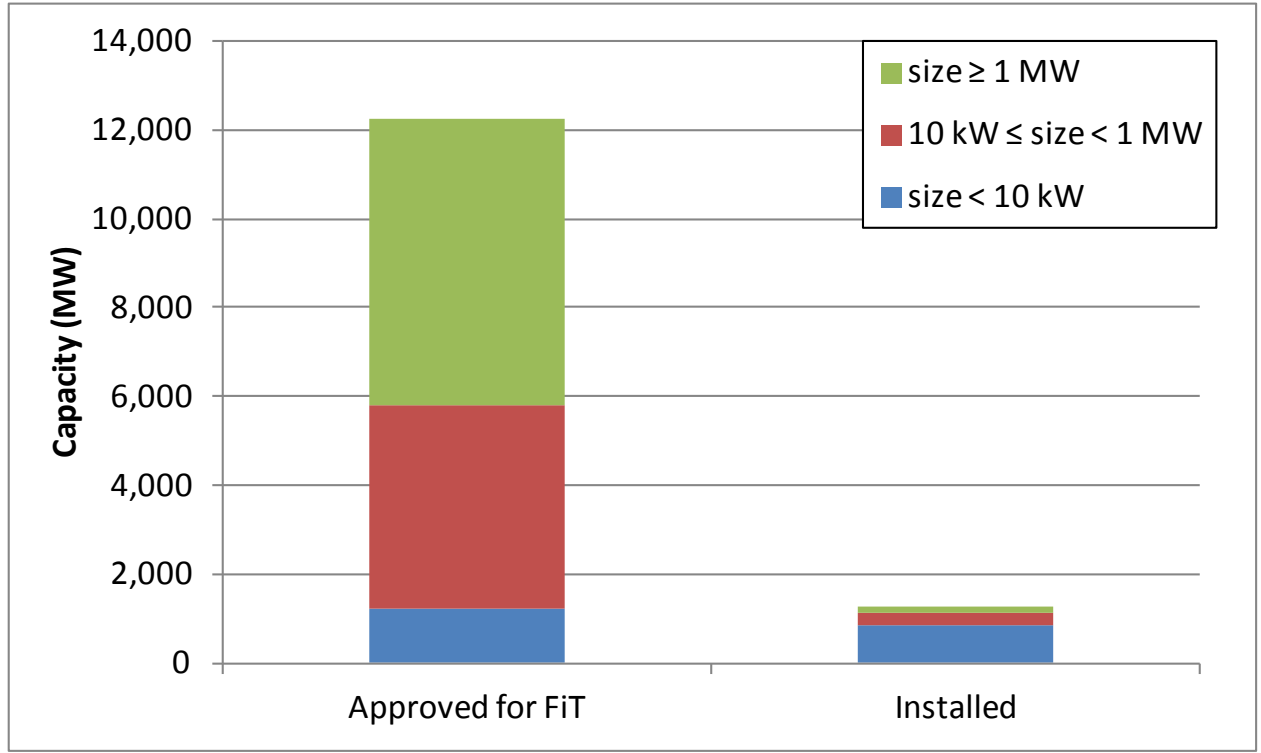

Figure 5. Capacity of PV systems approved for FiT in Japan by METI (384,390 systems) and installed (193,343 systems), July 2012-February 2013

Source: RTS Corporation (2013)

\footnotetext{
${ }^{8}$ Hokkaido Island's generation capacity is only $7.2 \mathrm{GW}$, and the capacity of transmission lines between the main island and Hokkaido is $0.6 \mathrm{GW}$.
} 


\subsection{Japanese and U.S. PV Policies and Market Attributes}

Japan has implemented a more managed, centralized policy strategy with closer cooperation among government, utilities, and industry compared with the United States. ${ }^{9}$ Unlike the United States, Japan also has used policy effectively to tie energy efficiency to PV and as a lever to reduce PV system prices. In some Japanese regions, for example, solar subsidies are only given where energy-efficiency measures have been implemented, which is partly responsible for the country's proliferation of home energy management systems (HEMs). Japan has several major overlapping policy initiatives:

- The FiT, which replaced a net-metering requirement in place since the early 1990s requiring utilities to purchase excess power at a premium (Burger 2012)

- The national cash subsidy administered by the Japan Photovoltaic Expansion Center (JPEC), the Japanese PV industry association

- More than 900 city and prefecture subsidy programs, ranging from cash rebates (e.g., $\$ 500$ per system) to low-cost loans to tax incentives, often capped at various levels (James et al. 2014).

There are no penalties for combining local and national incentives, and the FiT may be combined with the national cash subsidy for systems smaller than $10 \mathrm{~kW}$. Combined incentives are also available in the United States, which more typically employs utility incentives not seen in Japan beyond the FiT. Despite limited land availability and low insolation (Figure 6), Japan has employed its robust policy mix to create more per-capita PV capacity growth than the United States. Japan's local incentives have been particularly important, surpassing both local gross domestic product and insolation as market drivers (Burger 2012). Section 6 discusses the attractive consumer economics produced by Japan's national PV policies.

\footnotetext{
${ }^{9}$ Japanese managers in each of these three sectors often maintain close personal relationships developed while attending university together.
} 


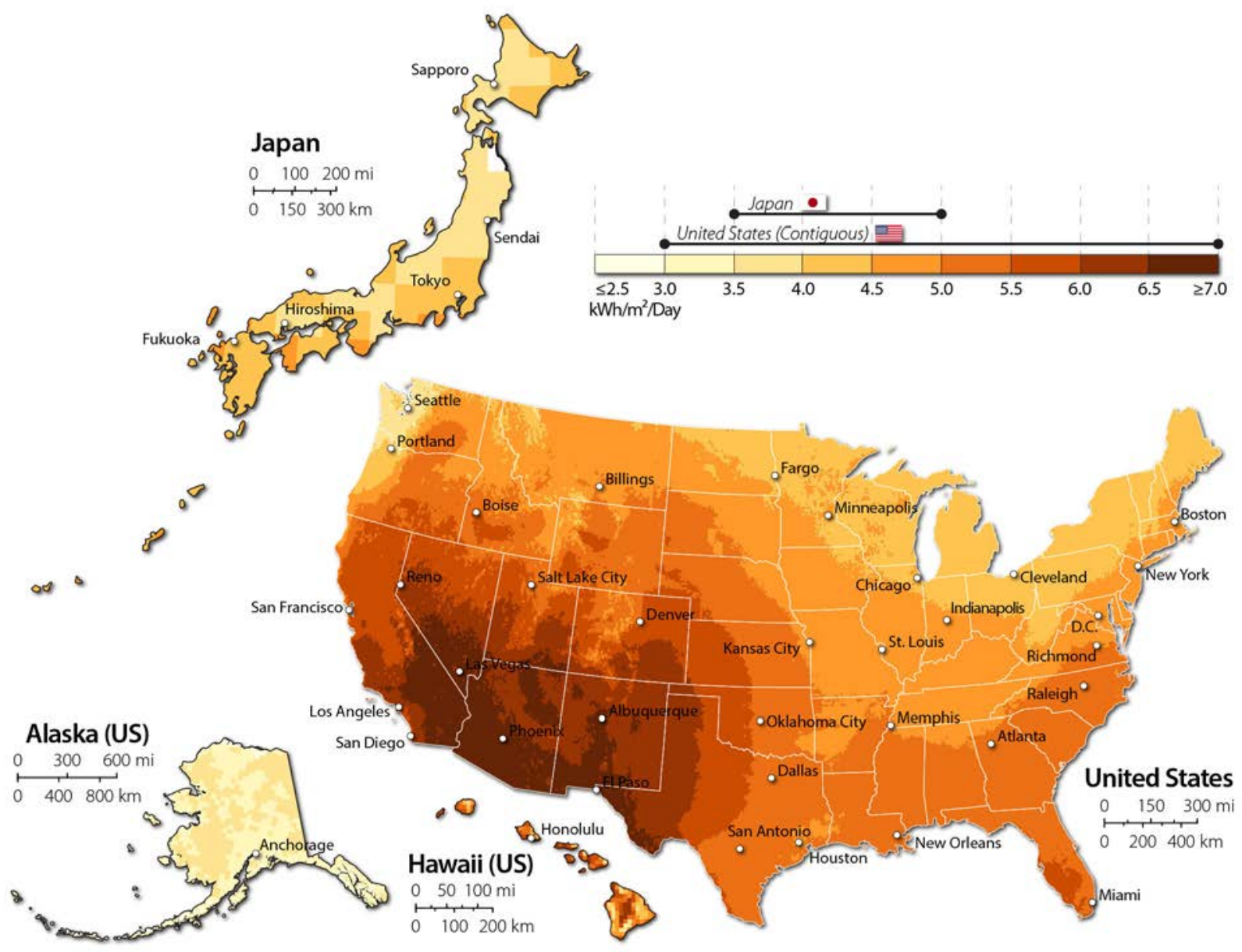

Figure 6. Comparison of Japanese and U.S. solar resource, with some similarity between Japan's solar resource and that of the northeastern United States

Notes/sources: Annual average solar resource data are shown for a tilt = latitude collector. The data for Hawaii and the 48 contiguous states are a 10-km satellite modeled dataset representing data from 1998-2009. The data for Alaska are a 40-km dataset produced by the Climatological Solar Radiation Model. Both the 10-km and 40-km datasets are available from NREL at http://www.nrel.gov/gis/data_solar.html. Solar data for Japan were obtained from the NASA Langley Research Center Atmospheric Science Data Center Surface Meteorological and Solar Energy (SSE) web portal supported by the NASA LaRC POWER Project (https://eosweb.larc.nasa.gov/sse/).

The structures of PV markets in Japan and the United States also differ. Japan's market relies on a more complex supplier/installer network that has been in place for decades and includes solar and various non-solar businesses (Figure 7). The Japanese system has two tiers within wholesale distribution, and the control of market channels rests primarily in the hands of manufacturers, most notably the three dominant domestic suppliers: Sharp, Kyocera, and Solar Frontier. In contrast, large integrators exert much more market influence in the United States. In addition, other key market actors play a role in PV distribution in Japan but not in the United States. These include large distributors and "trading companies," housing manufacturers, renovation companies, and real estate developers. The large distributors and trading companies primarily function as wholesale distributors. Housing manufacturers often buy directly from PV manufacturers for the new home construction market. 
The U.S. market has fewer distribution channels and mark-ups that increase retail prices. In Japan, there are many ways a PV module may be integrated into a kit and make its way through the wholesale market to the retail customer, including through the trading companies, manufacturers' own wholesale or retail outlets, big-box stores, and various combinations of these. Mark-ups throughout this supply chain vary widely depending on the companies and regions involved, ranging from $5 \%$ to $50 \%$. These distribution channels have contributed to Japan being among the more expensive PV markets globally.

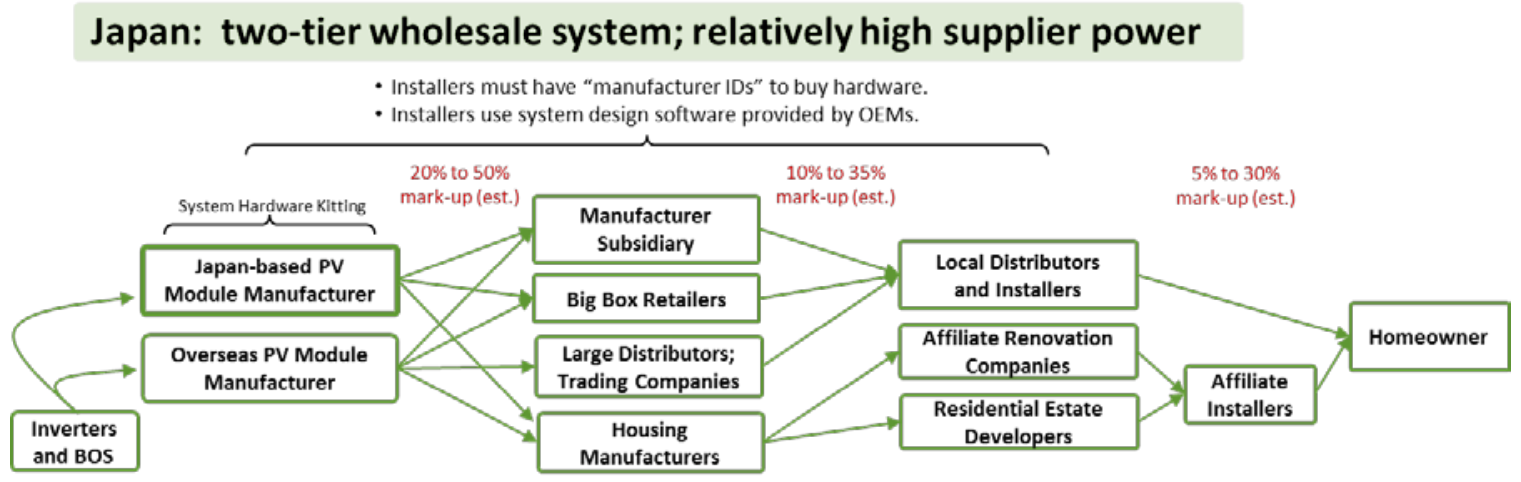

United States: hardware pricing driven by large integrators; high buyer power

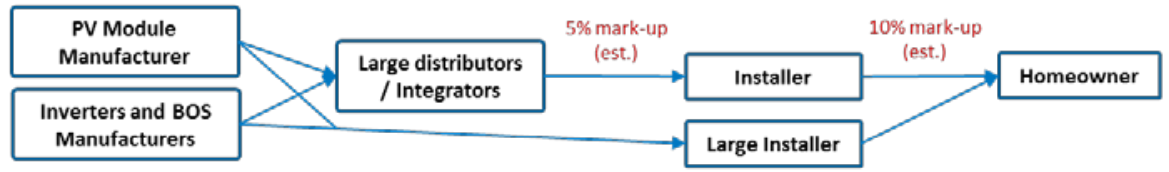

Figure 7. Structural distinctions between Japanese and U.S. PV markets

Source: James et al. (2014)

Through non-solar business lines, most notably in the electronics and appliance sectors, Japanese PV installers often develop relationships with domestic module manufacturers who also maintain a presence in the other sectors. The installers' customers typically develop confidence in a PV product through identification with a Japanese brand and may be more willing to pay a premium for those brand associations. Installers apply, test for, and receive major domestic manufacturers' "identifications (IDs)," essentially a license to sell and install kits made by these manufacturers. The IDs require recertification once per year, which an installer may find difficult to maintain for multiple manufacturers. Conversely, the installer may effectively function as the exclusive dealer of the brand in a specific city or prefecture. The ID requirement can serve as a barrier to entry for new entrants and foreign competitors. It remains unclear how long the dominance of higherpriced domestic brands will last in the face of downward price pressure due to foreign competition (see Section 4) and policies explicitly encouraging price reductions.

The major Japanese module manufacturers also supply their installers with their own versions of system-design software, which can reduce design costs through standardization. From our 
discussions with installers about these software systems, we learned that installers commonly can design a system in 30-40 minutes with no engineering labor.

Although maintaining relationships with module manufacturers and end-use customers is essential for Japanese PV installers, installers who have these relationships might focus more on other businesses and lack PV-installation skills. Such companies often subcontract the actual installation work.

We summarize the similarities and differences between the Japanese and U.S. PV markets as follows: ${ }^{10}$

\section{Similarities between the Japanese and U.S. PV markets:}

- Layered local and national incentives drive market.

- Utility-scale projects are taking progressively more market share.

- An aging population with disposable income is helping drive residential growth.

- Regulatory and interconnection hurdles have delayed large utility-scale projects.

- There is a mismatch between available land for utility-scale PV and customer load.

- Qualified labor supply shortages and quality-control risks are associated with inconsistent installer training. In Japan, these are a direct result of rebuilding following the Fukushima disaster and interconnection challenges incurred by utilities.

- There has been a rapid influx of Chinese modules, constituting about $45 \%$ of shipments in the first quarter of fiscal year 2013 in Japan (PHOTON Consulting 2013).

\section{Differences between the Japanese and U.S. PV markets:}

- Japan's market participants emphasize customer value and relationship over price. Module brand recognition and allegiance is more of a sales driver in Japan than in the United States. Japanese customers proactively seek recognized brands much more than is typical for U.S. customers.

- Japan has very little third-party ownership, whereas the U.S. market is now dominated by this ownership model.

- There is more of a unified national market relying on national policies in Japan, compared with the U.S. emphasis on state markets.

- Japan's market, unlike the U.S. market, is dominated by the use of turnkey PV kits.

- No permitting is required for Japanese systems smaller than $50 \mathrm{~kW}$.

\footnotetext{
${ }^{10}$ The comparisons are based primarily on our discussions with installers in Japan as well as our knowledge of the U.S. market, including discussions with U.S. installers conducted as part of NREL's primary research on cost benchmarking.
} 
- Generally, Japanese equipment prices are higher than U.S. prices, because the market structure generally favors suppliers in Japan and buyers in the United States.

- Japan's supplier-controlled channel strategies make installers' barriers to entry more significant in Japan.

- Broadly speaking, Japanese systems provide better economic returns than those in the United States, with some exceptions. This is due in part due to high electricity prices driving commercial and utility-scale solar interest, comparable to high-priced U.S. markets like California and Hawaii.

- Some local incentives in Japan have the effect of driving down PV price by stipulating price ceilings for eligibility. In addition, some local PV incentives in Japan tie the PV incentive to a requirement of concomitant energy-efficiency measures.

- Japanese installers build operations and maintenance into their budgets more consistently because of their emphasis on local presence and relationships. Operations and maintenance plans vary from simple cleaning to multi-year service contracts. In the United States, service plans vary, and orphaned systems, such as systems installed by companies that are no longer in business, are more common.

- Japanese business models may better reduce customer-acquisition cost; typically this cost in Japan is about $1 \%-3 \%$ of system price, compared with $9 \%-10 \%$ in the United States.

- Japanese costs are greater for high-cost domestic/brand-name modules and other hardware as well as for overhead incurred through multiple layers of distribution.

- Discussions with installers revealed a common perception that the currently strong growth of the market would likely not sustain itself for more than 1-2 years.

- There are more finance-related bottlenecks in the United States. Finance-related challenges in Japan's market tend to be limited to foreign and new entrants.

- Japan has a 5\% tax on all systems; in the United States, system taxes typically range from $0 \%-7 \%$.

\section{Japanese and U.S. Residential PV Prices and Costs}

Since 2001, Japan's residential PV system prices have been lower than U.S. prices, although the gap narrowed in recent years (Figure 8). Based on our data and analysis, the weighted-average residential system price in Japan for $1 \mathrm{H} 13$ was $\$ 4.64 / \mathrm{W}$ (Figure 9), compared with $\$ 4.92 / \mathrm{W}$ in the United States. Of these prices, soft costs constituted $44 \%$ in Japan versus $67 \%$ in the United States. However, the 2013 price declines in Japan may be even more significant: BNEF's database of current installed Japanese residential systems indicates prices have declined to $\$ 3.45 / \mathrm{W}$ in October 2013 (Woodward 2013b), whereas the most recent price figures for U.S. residential systems are in the $\$ 3.75-\$ 4.25 / \mathrm{W}$ range (Shiao 2013). ${ }^{11}$ The rapid price reduction in Japan is primarily due to the fact that low-cost Chinese modules shipped into Japan have become more accepted and commonly deployed in recent months. The uptake of Chinese modules is still mainly focused on large-scale projects. In contrast, in the residential market SunPower has

${ }^{11}$ GTM Research's average U.S. price for 2013 is $\$ 4.04 / \mathrm{W}$ (Shiao 2013). 
significantly increased its residential market share through its partnership with Toshiba (RTS 2013). Figure 10 shows component price differences between U.S. and Japanese residential systems. This figure compares U.S. 1H12 systems with Japanese 1H13 systems because 1 H12 is the most recent period for which detailed U.S. price data are available.

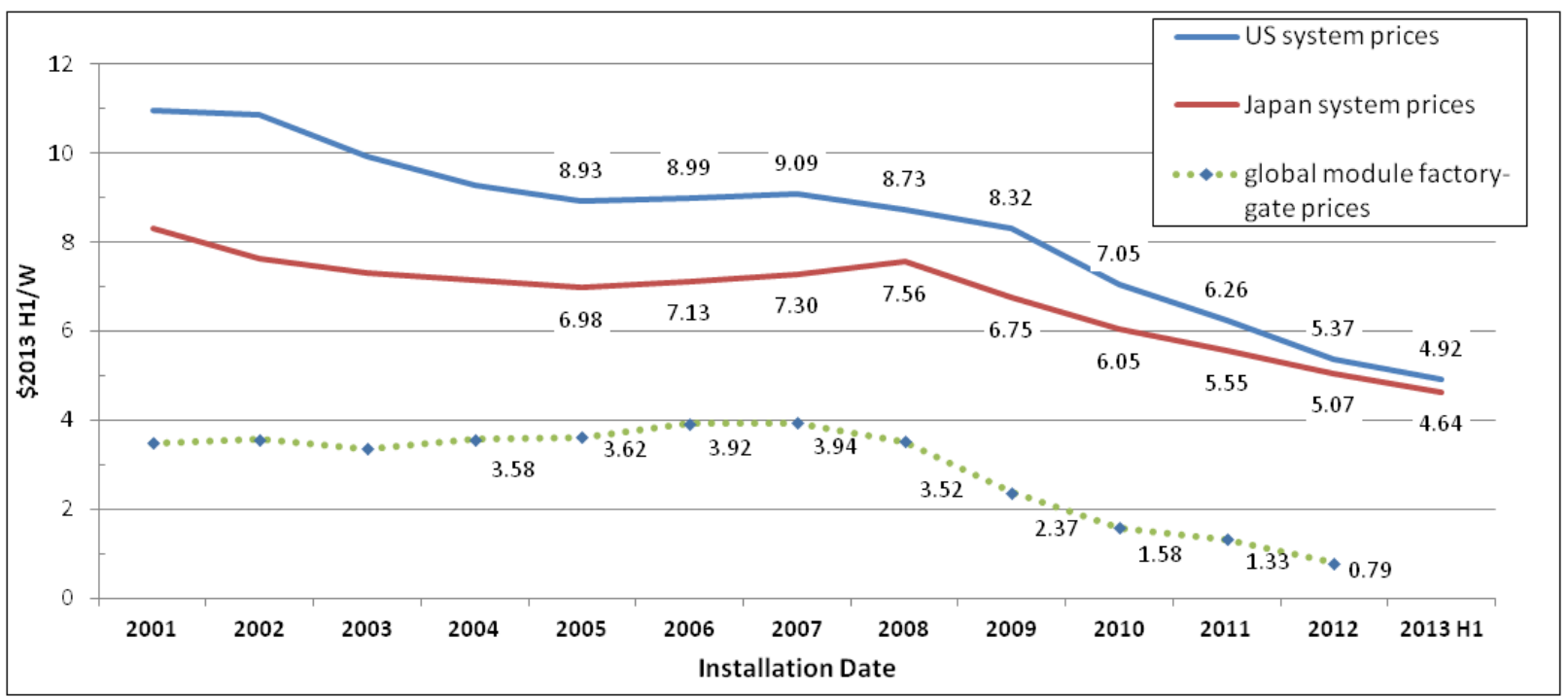

Figure 8. Median installed system prices for residential PV Systems of $10 \mathrm{~kW}$ or less, United States versus Japan, 2001-1H13

Sources: Barbose et al. (2013), METI (2013), Mints (2013), UBS Investment Research (2013) 


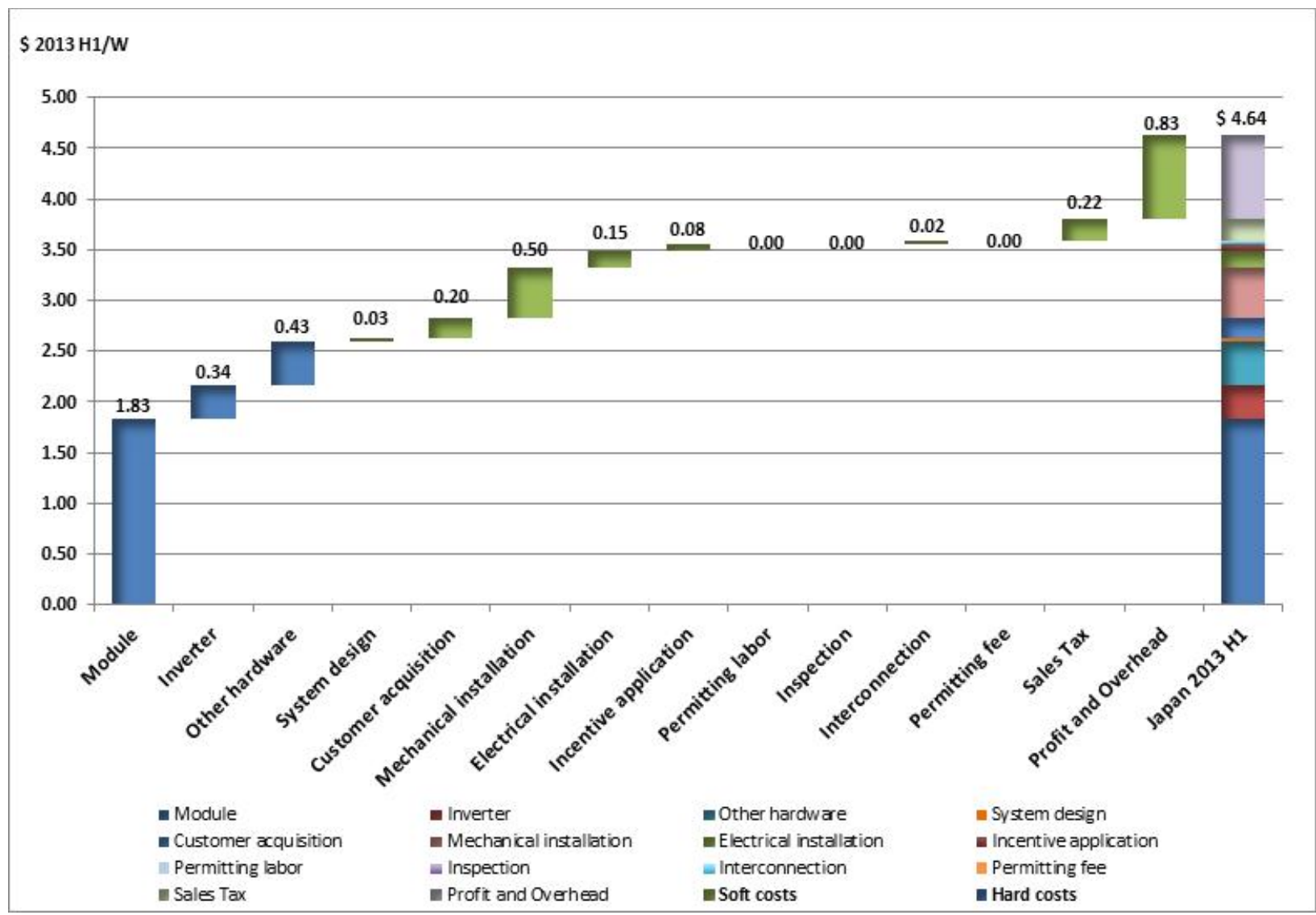

Figure 9. Components of Japanese residential PV system price in $1 \mathrm{H} 13$

Notes: *Operational profit is a term meant to encompass profit and overhead, as it is very difficult to distinguish between these. The shaded green areas denote soft costs; shaded blue denote hardware costs. 


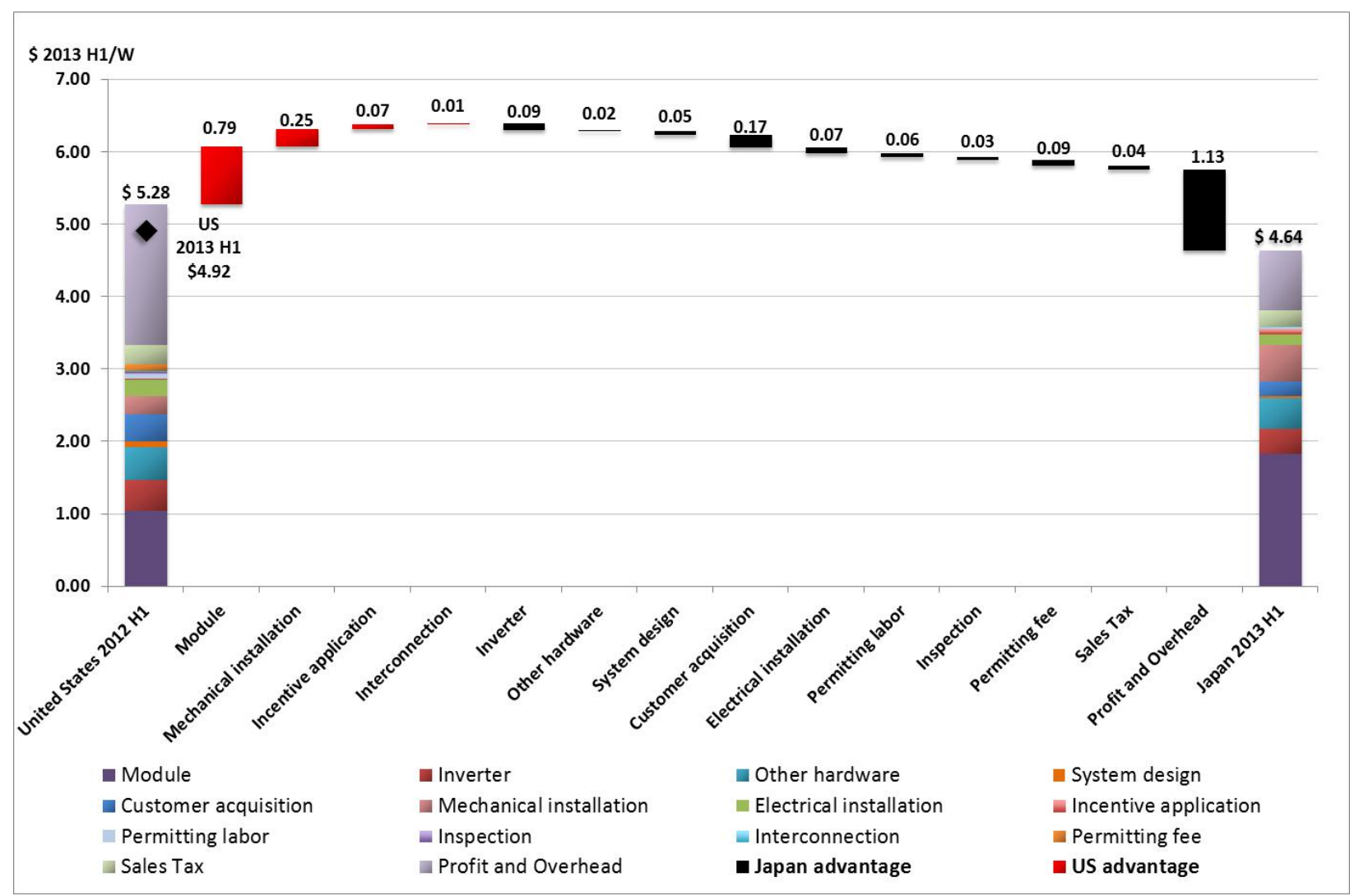

Figure 10. Price differences between U.S. (1H12) and Japanese (1H13) residential systems

The characteristics of the U.S. and Japanese residential PV markets drive the price differences. In Section 3.3, we listed the similarities and differences between the Japanese and U.S. PV markets in general. Here we summarize distinctions between their residential PV markets specifically: $^{12}$

- Japan has a higher percentage of PV in new home construction compared with residential PV retrofits; new homes represented 30\% of Japan's total residential PV market in 2012. In contrast, the proportion was 13\% in California during the same period (Movellan 2013). Japan also has a greater emphasis on energy efficiency, particularly in new "ecohome" or "smart home" construction (energy-efficient homes employing HEMs and sustainable materials).

- Although there is a limited big-box market for PV in the United States, Japanese installers rely more heavily on big-box stores for retail home PV system shopping. PV systems are often strategically placed in store displays.

- Japanese installers often add materials to satisfy customers' aesthetic preferences, such as smoothing the corners of arrays. In some U.S. regions, costs are incurred for additional materials to protect panels from animals like squirrels, which are not a factor in Japan.

\footnotetext{
${ }^{12}$ The comparisons are based primarily on our discussions with installers in Japan as well as our knowledge of the U.S. market, including discussions with U.S. installers conducted as part of NREL's primary research on cost benchmarking.
} 
- In the United States, additional soft costs are incurred for in-house engineering expertise not typically required for Japanese residential systems. This is because Japanese installers typically employ a more standardized approach to system design, utilizing software supplied by major PV manufacturers. More customization increases the time required for system design: 2-7 hours in the United States compared to less than 1 hour in Japan where manufacturers provide design software.

- In Japan, structural inspections are rare. Utilities often require both an initial inspection and a final inspection, but, unlike in the United States, installers do not typically need to be present.

- Some Japanese installers use scaffolding, whereas most U.S. installers use ladders instead. Scaffolding can add cost, although it may be more efficient and safer on some jobs.

- Subsidy applications tend to be simpler in Japan, even though installers and/or customers typically cannot file paperwork electronically.

- Large homebuilders and remodelers dominate Japan's residential market. Pure PV players only recently have entered the market.

- Japan's typical residential rooftop space is considerably smaller than in the United States.

- The typical household electricity consumption in Japan is approximately 300

$\mathrm{kWh} /$ month, less than a third of U.S. consumption (EIA 2013).

The following sections detail the Japanese residential PV cost results from our interview data compared with U.S. costs. ${ }^{13}$ In the soft cost sections, we compare Japanese residential soft costs for $1 \mathrm{H} 13$ with U.S. residential soft costs for the half-year period 1 year earlier (1H12) because $1 \mathrm{H} 12$ is the most recent period for which detailed U.S. primary data are available. As Figure 11 shows, the resulting comparisons are meaningful because U.S. soft costs changed little between 2012 and 2013 (i.e., hardware cost reductions drove the decline in U.S. system price during that period). Figure 11 also includes modeled costs for the first half of 2013 in the United States to provide a more recent frame of reference. We include the older 2012 data alongside these more recent data, because the 2012 data are based on a survey (primary data) and not cost modeling, which supports direct comparison with the Japanese data, which are also based on a survey.

\footnotetext{
${ }^{13}$ All Japanese capacity-weighted averages were calculated based on the actual average system size for residential
} systems of a given installer, not an assumed system size. 


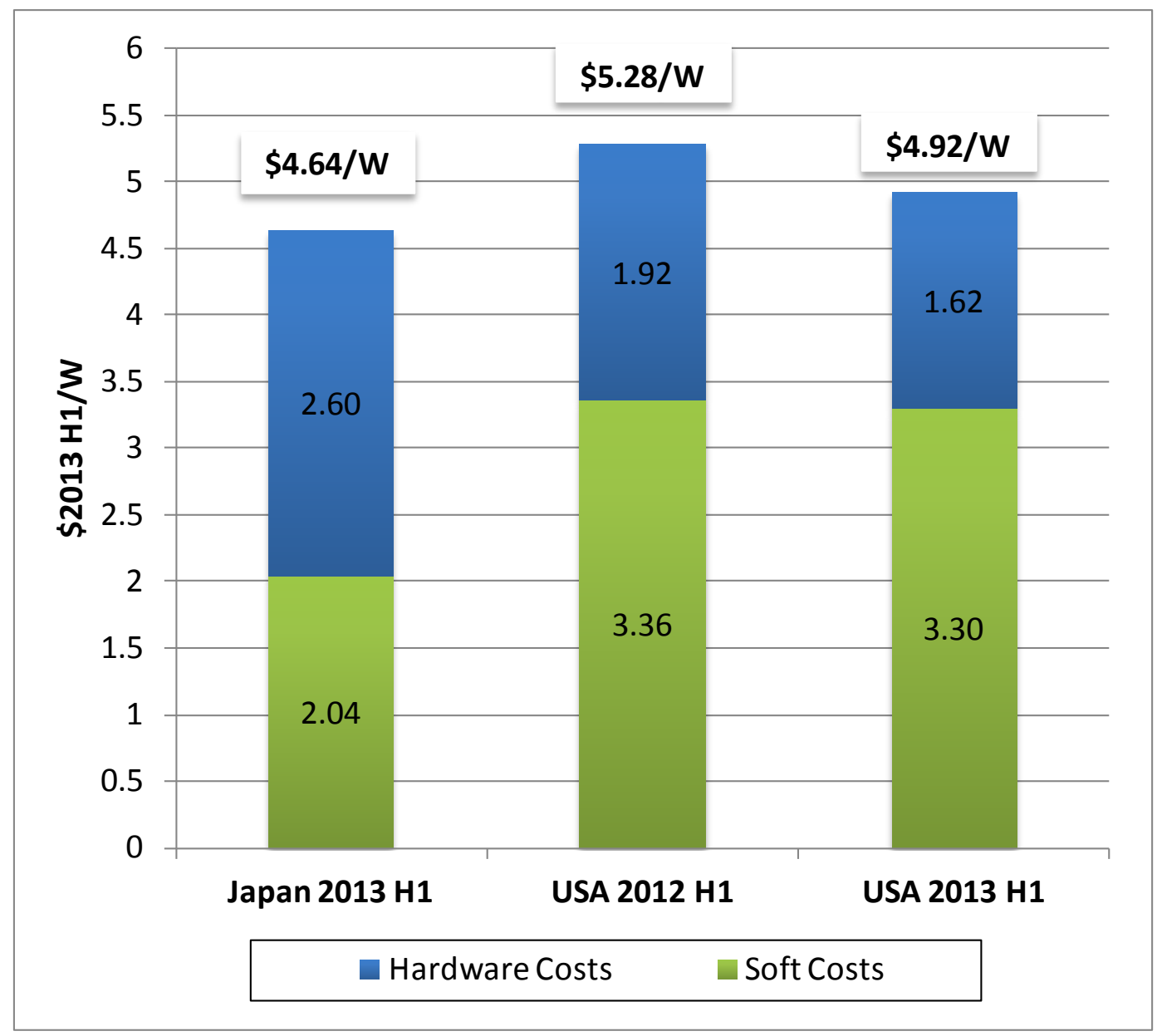

Figure 11. Comparison of total residential PV system hardware and soft costs among Japan (1H13), the United States in 1H12, and the United States in 1H13, showing that most of the decline in U.S. system price between 2012 and 2013 was due to hardware cost reductions

\subsection{Hardware}

Residential PV hardware costs in Japan for $1 \mathrm{H} 13$ totaled \$2.60/W (Figure 12). The relatively high hardware costs are due to the Japanese consumer preference for domestic module brands, which are often sold at premium prices. 


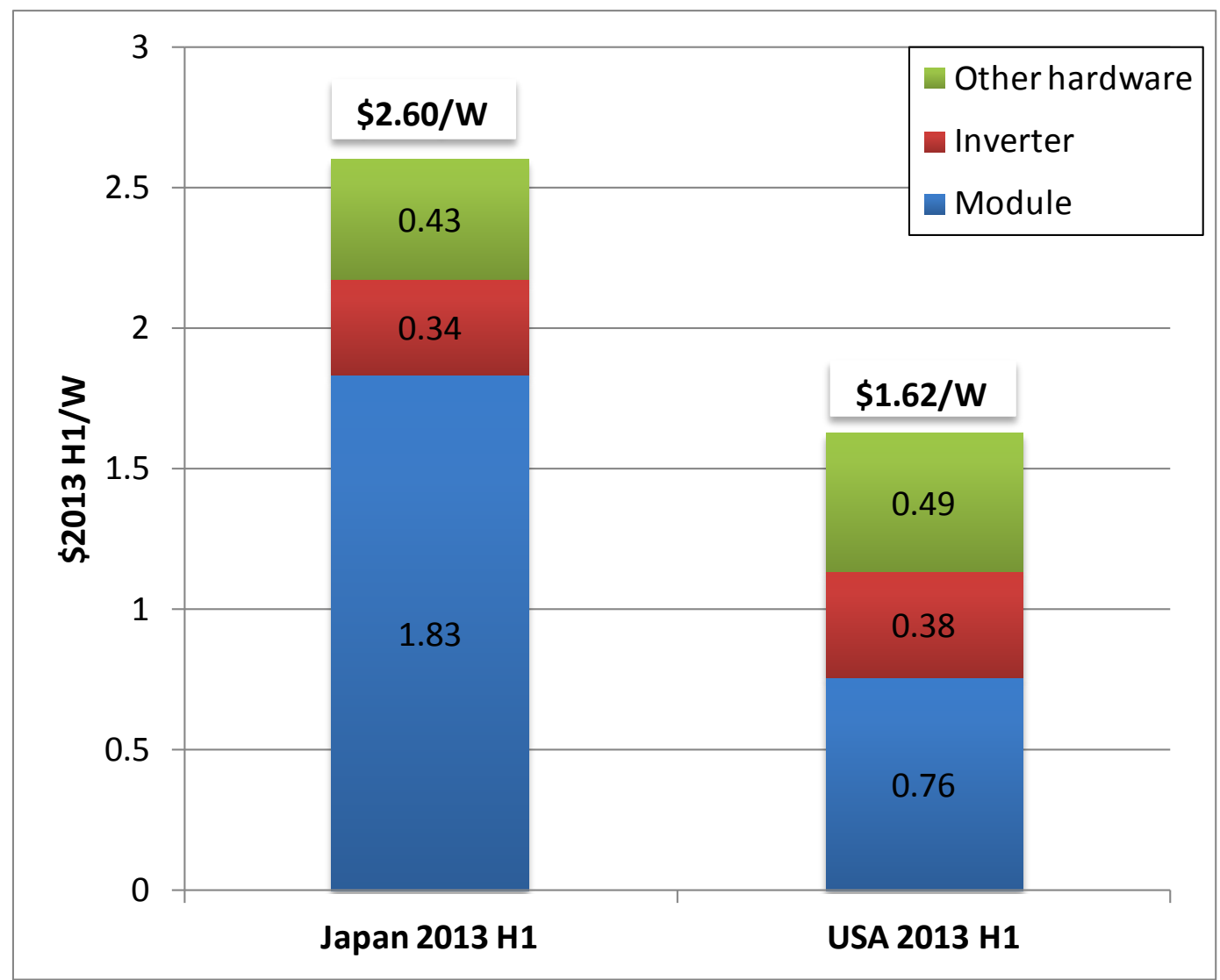

Figure 12. Japanese (capacity-weighted average) and U.S. residential PV hardware costs, $1 \mathrm{H} 13$

Increasing competition from lower-priced, foreign-manufactured modules - from countries such as China and the United States - is likely driving down Japanese hardware costs. In 2Q13, domestically manufactured modules made up less than half of Japan's shipments for the first time, following a yearlong decline in domestic module market share (JPEA 2013, Figure 13). However, nearly half of the import volume came from Japanese manufacturers with production facilities owned abroad and from original equipment manufacturing facilities developed through outsourcing to foreign companies (Woodward 2013a). High Japanese demand has enabled both domestic and foreign module manufacturers to thrive thus far.

The recent entrance of pure-play PV installers, including foreign companies, into the Japanese market might also help drive hardware prices down. Since these installers often cannot compete with Japan's traditional "multi-tasking" residential installers - who provide multiple, sometimes unrelated, products and services to their customers - on brand or customer relationships, they typically must compete on price by using lower-cost modules and hardware components. Our data show that the average residential hardware cost for installers who commit more than two thirds of their business activity to PV is $9 \%$ lower than the cost for those who commit one third to two thirds and $12 \%$ lower than the cost for those who commit less than one third. This competition also reduces system prices, although it is unclear whether it is increasing installation efficiency or merely reducing operational profits. 


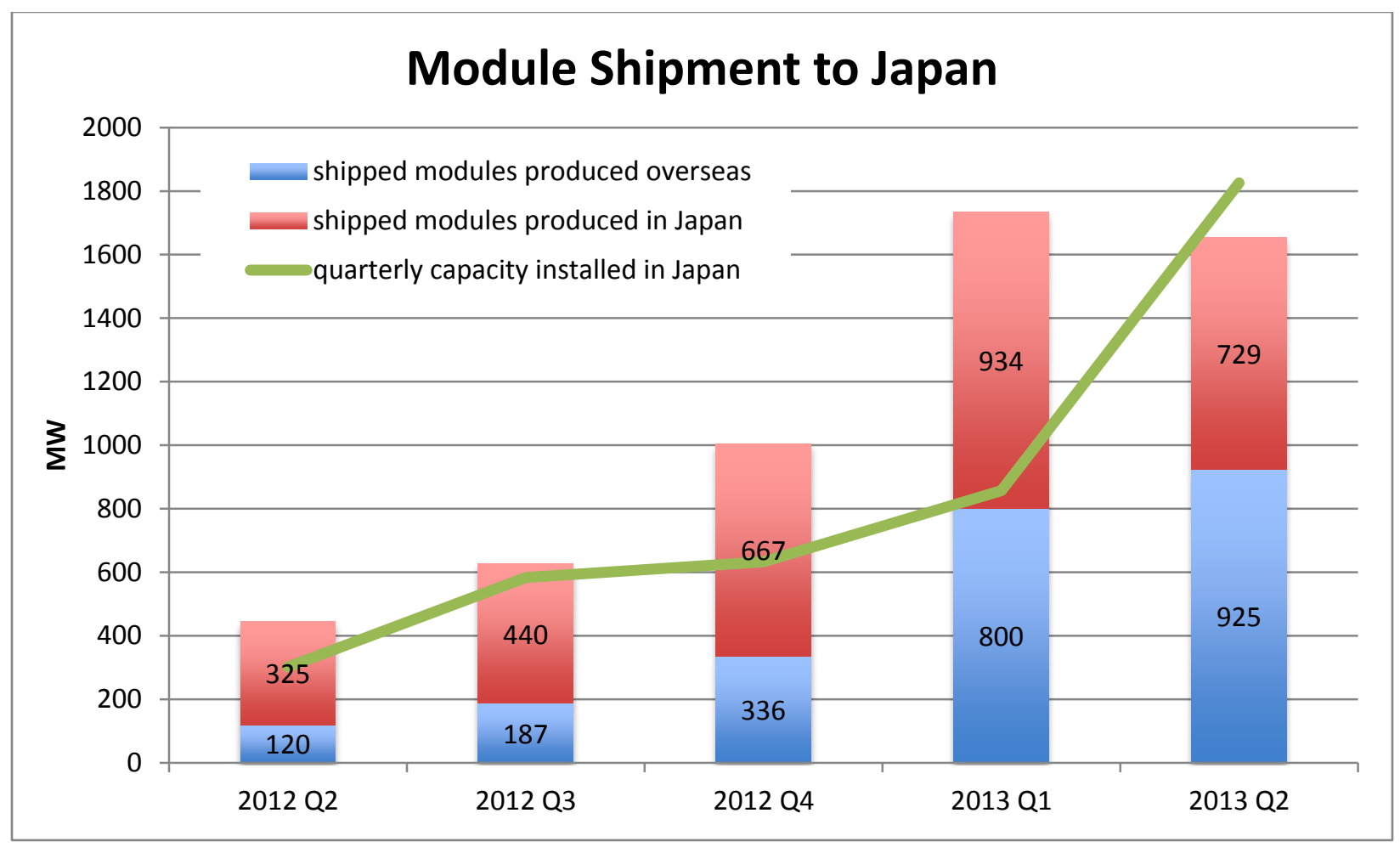

Figure 13. Shares of foreign and domestic module shipments in Japan, 2Q12-2Q13

Source: JPEA (2013), METI (2013)

\subsection{Customer Acquisition and System Design}

Capacity-weighted average residential customer-acquisition and system-design costs in Japan were $\$ 0.23 / \mathrm{W}$ in $1 \mathrm{H} 13$. This was half the corresponding U.S. costs in $1 \mathrm{H} 12(\$ 0.46 / \mathrm{W})$.

Figure 14 compares the two countries' costs. There are several reasons for Japan's cost savings. First, Japanese installers most often have existing business relationships with their PV customers for other products and services. Their strategy is to cross-sell PV, capturing more of the customer dollar and lowering the marginal cost per PV sale. These "multi-taskers" typically engage in a wide variety of business activities, ranging from construction, renovation, and remodeling (the most common) to electrical and roofing work. Even some otherwise-unrelated businesses like car and appliance dealers install PV as well. This strategy is cost effective-spreading sales, installation labor, customer acquisition, and overhead costs across the multiple business lines and resulting in higher operating margins and, potentially, lower system prices. This cross-selling strategy also capitalizes on customer loyalty and existing relationships, giving multi-taskers a customer-acquisition advantage over pure-play PV installers with no existing customer base. ${ }^{14}$ Until recently there were few or no pure-play installers in Japan because of their inherent disadvantage. Our data show that the average customer-acquisition and system-design cost for installers who commit less than one third of their business activity to PV is up to $71 \%$ lower than the cost for installers who commit more than one third of their business to PV. This is likely due to their superior ability to leverage customer relationships built through other business lines.

\footnotetext{
${ }^{14}$ Similarly, installers with local customer relationships can enjoy a competitive advantage versus larger companies with a wider reach, such as national homebuilders that install PV.
} 


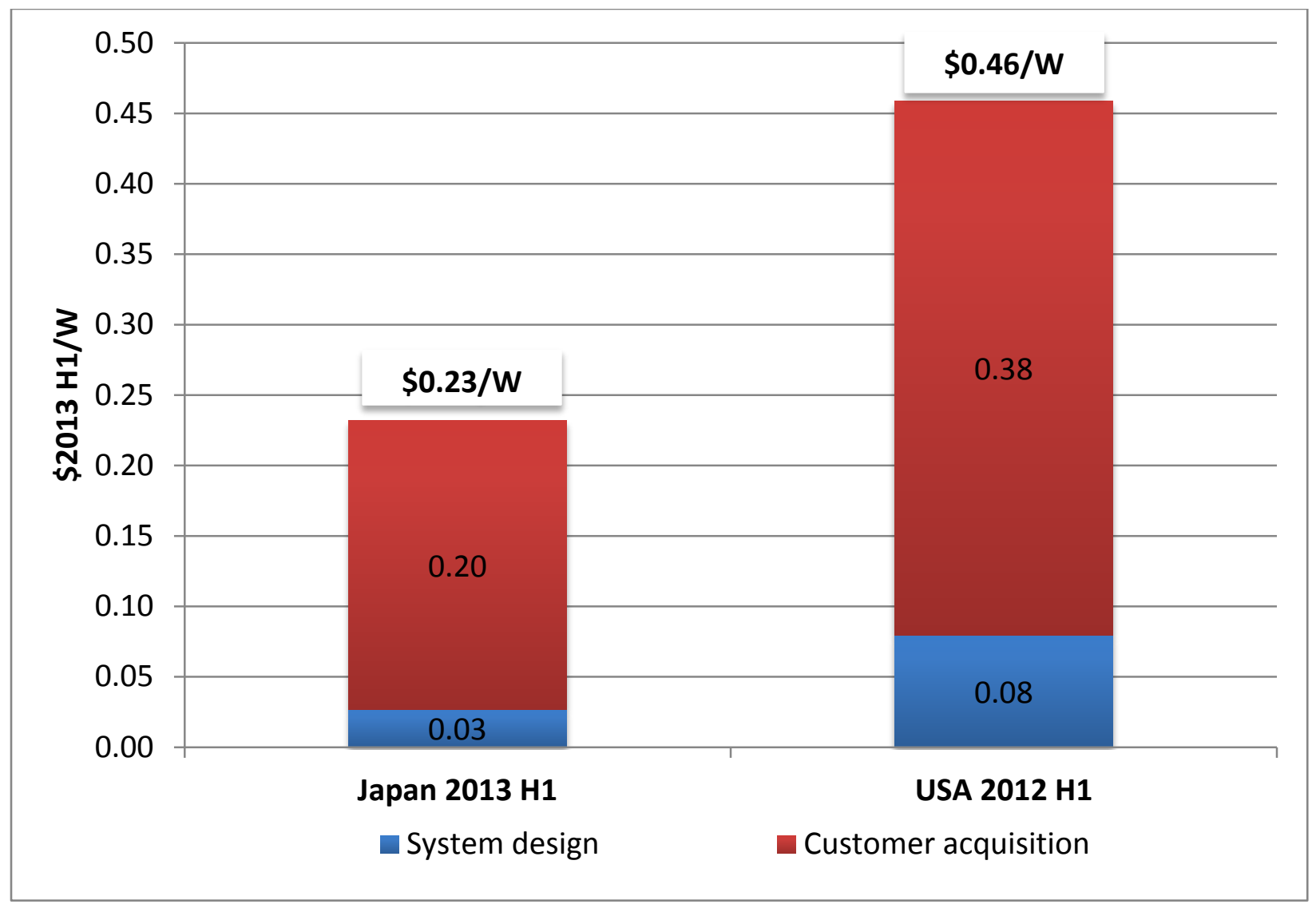

Figure 14. Japanese (1H13) and U.S. (1H12) residential PV customer-acquisition and systemdesign costs (capacity-weighted averages)

Second, Japan's residential customer-acquisition and system-design costs are lower than U.S. costs because the barriers to sale are significantly diminished. This is because Japan's IRRs on PV projects are so favorable (anecdotally often in the double digits) and because the Japanese public and policymakers have sought PV so proactively post-Fukushima. Finally, Japanese PV systems are designed almost exclusively using standard designs produced with a limited number of software systems. Frequently, Japanese installers reported spending less than 1 hour on system design, which made Japan's design costs less than half of U.S. costs.

\subsection{Installation Labor}

Unlike the other soft cost categories, updated 1H13 data on U.S. installation labor are available via a study conducted by the Rocky Mountain Institute in 2013 (Nick et. al. 2013). For this reason, installation labor is the only soft cost category for which direct comparison for the same periods is possible. Capacity-weighted average residential labor costs in Japan were $\$ 0.65 / \mathrm{W}$ in $1 \mathrm{H} 13$, compared with $\$ 0.48 / \mathrm{W}$ in the United States (Figure 15). Japanese installers required about 5 more hours per kilowatt of PV installed.

This result is surprising, given the use of labor-saving kits in Japan and the overall higher experience one would expect with a larger residential market. One possible reason is that more inexperienced new-entrant installers might be taking advantage of increased demand following Fukushima. Further, electrical labor in Japan is generally less expensive than mechanical labor, 
possibly because the electrical labor pool is typically used for mechanical labor in Japan, particularly during the current period of mechanical labor supply constraints. This could skew the labor costs for the two pools. In addition, less-skilled mechanical and electrical labor might be replacing some of the higher-skilled labor in high demand for various rebuilding efforts following the disaster. Another possibility is that installing PV on the tile roofs common in Japan, as well as waterproofing these tile roof penetrations, may require more labor hours than installing it on the shingle roofs common in the United States (Alfsen 2011). However, these reasons for the higher costs and hours in Japan are speculative, and more research would be required to test these hypotheses.

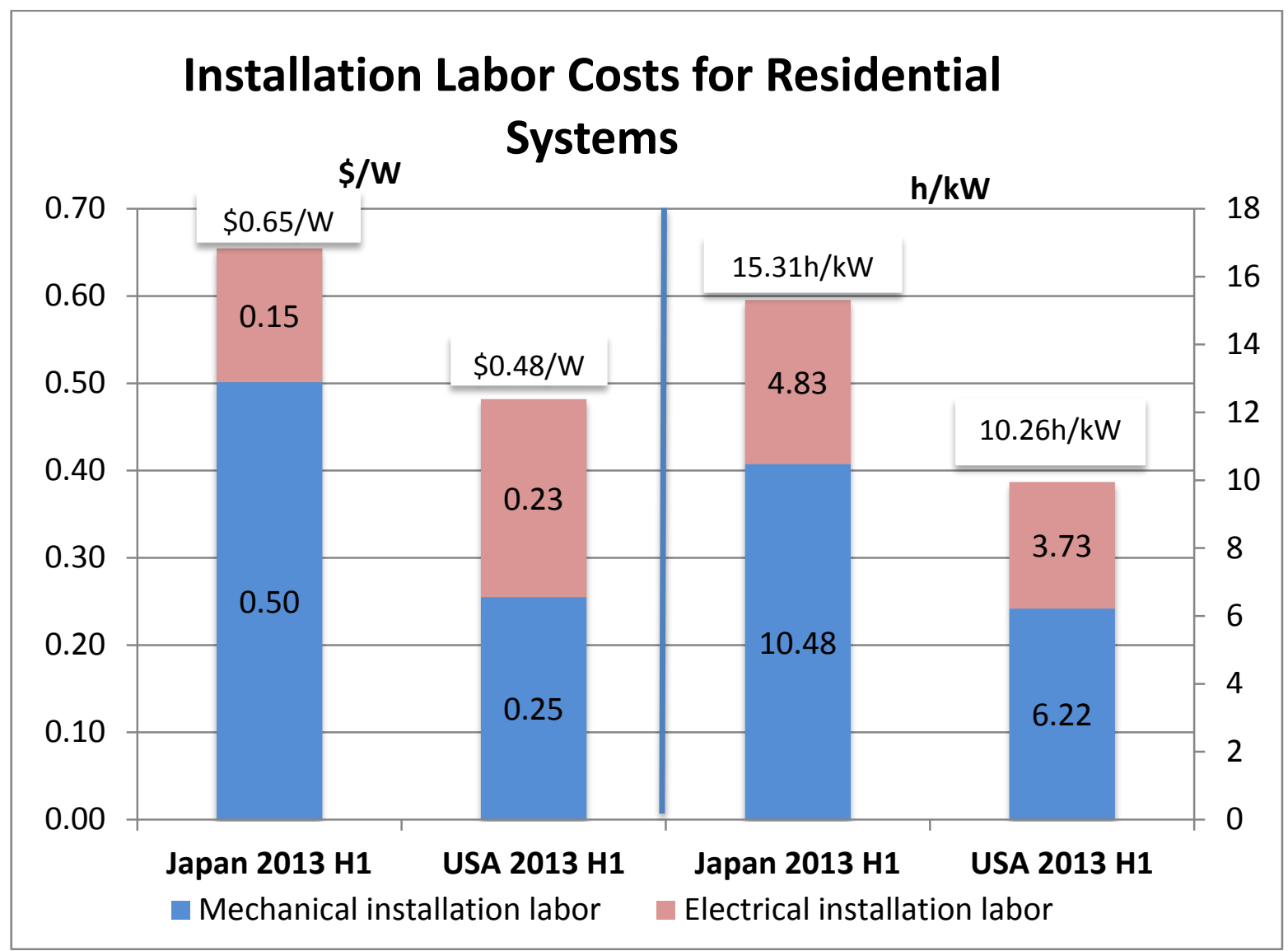

Figure 15. Japanese (1H13) and U.S. (1H13) residential PV installation-labor costs and time requirements

Source for U.S. data: Nick et al. (2013)

As Figure 16 shows, Japanese electrical labor wages for residential installations are one third lower than mechanical labor wages. Japan's mechanical labor wages are higher than U.S. mechanical labor wages as well. Combined with the higher mechanical labor time requirements in Japan compared with the United States (Figure 15), this contributes to the higher overall cost of Japanese installation labor.

Importantly, the Japanese and U.S. labor costs were derived differently. For the U.S. figures, we multiplied surveyed installer-specific labor times by an industry-average wage rate to yield labor costs. This is why U.S. residential and commercial labor wage rates are the same (Figure 16). We 
derived the Japanese figures from surveyed installer labor times and from surveyed installer wage rates, thus we have direct data for both of these metrics in Japan and do not rely on an industry average as we do for the United States.

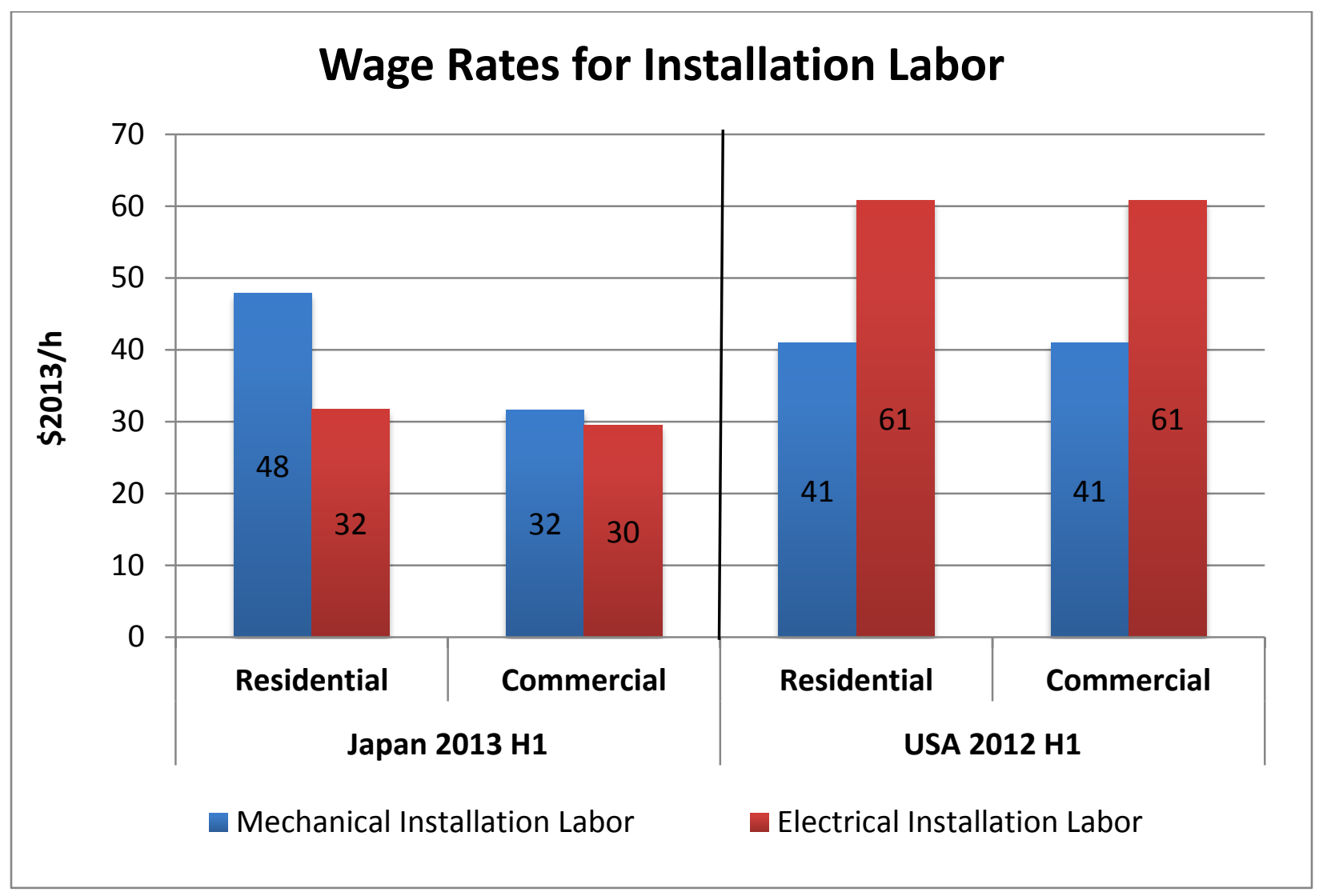

Figure 16. Japanese (1H13) and U.S. (1H12) mechanical and electrical mean labor wage rates ${ }^{15}$ Source for U.S.: RSMeans (2010)

\subsection{Permitting, Inspection, and Interconnection}

Capacity-weighted average residential PII costs in Japan were $\$ 0.10 / \mathrm{W}$ in $1 \mathrm{H} 13$, compared with $\$ 0.20 / \mathrm{W}$ in the United States in 1H12 (Figure 17). Installers in the United States also required about twice as many PII-related labor hours per PV system installed.

Because there is no distinct requirement for structural or electrical permitting for residential systems in Japan, the only labor hours incurred for these systems are associated with the incentive application and system interconnection. Some Japanese utilities do require preinstallation inspections, but in general installers are not required to be present for those inspections. Conversely, electricians registered with their utility can generally carry out their own final inspection prior to interconnection, without having to wait for a utility representative. There are two main reasons why Japan's incentive-application process takes more time than the U.S. process. First, local applications require a separate trip to the local authority-havingjurisdiction in Japan, because they cannot be processed online. Second, national and local 
subsidy applications require a seal from the customer (similar to what a signature would accomplish in U.S. culture) prior to the installation. This can result in extra travel time for installers to the customer site. In addition, the national and local subsidy application forms in Japan are separate and not integrated with each other.

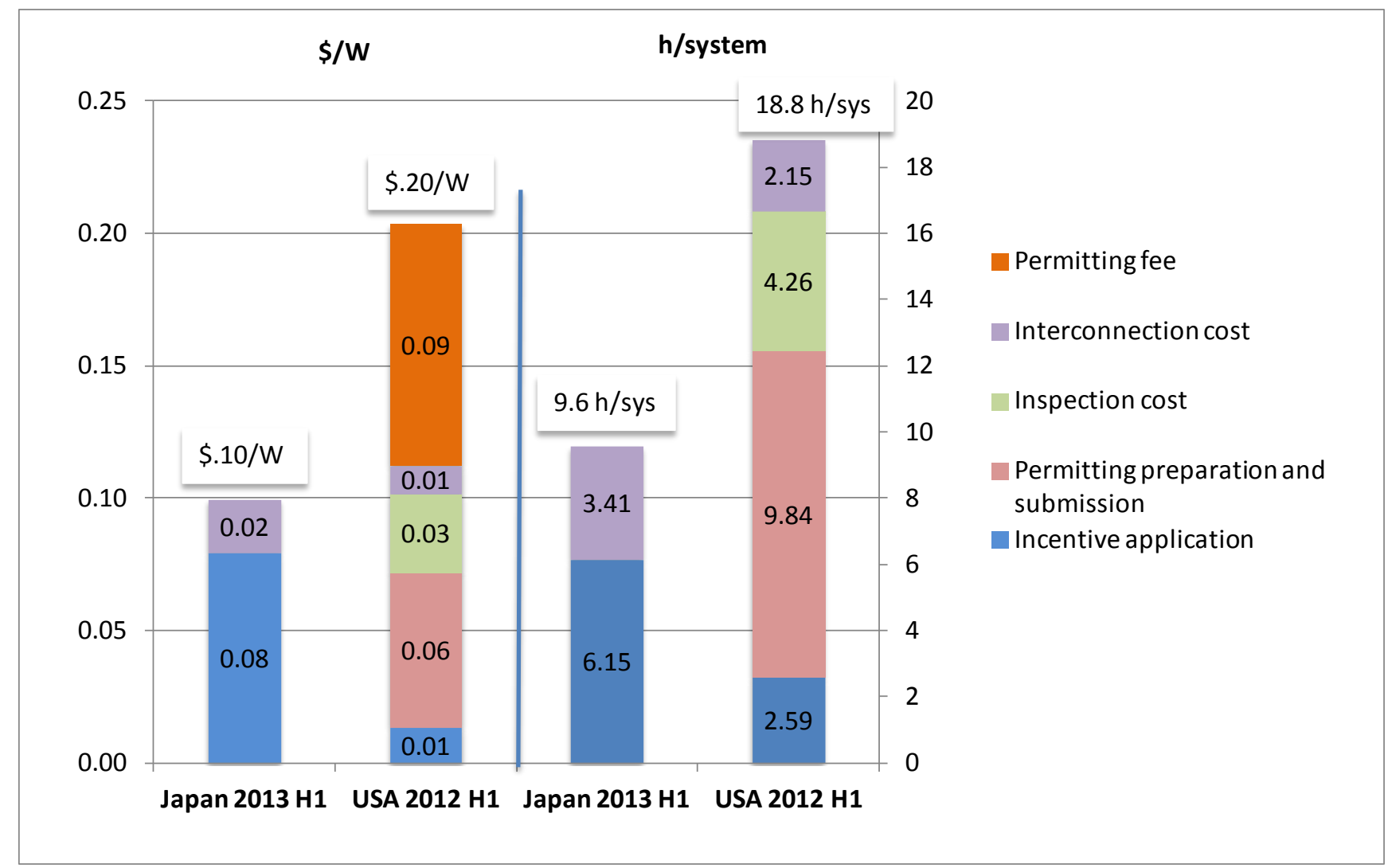

Figure 17. Japanese (1H13) and U.S. (1H12) residential PV PII costs and time requirements

Source for U.S.: Friedman et al. (2013) 


\section{Japanese and U.S. Small Commercial (10-50 kW) PV Prices and Costs}

Based on our data collection and analysis, the weighted-average small commercial (10-50 kW) system price in Japan for $1 \mathrm{H} 13$ was $\$ 3.59 / \mathrm{W}$ (Figure 18), compared with $\$ 4.51 / \mathrm{W}$ in the United States for the same period. ${ }^{16}$ Among the reasons for this are Japan's lower customer-acquisition and system-design costs ( $\$ 0.02 / \mathrm{W}$ versus $\$ 0.27 / \mathrm{W}$ in the United States), installation-labor costs ( $\$ 0.25 / \mathrm{W}$ versus $\$ 0.45 / \mathrm{W}$ in the United States), and PII costs $(\$ 0.01 / \mathrm{W}$ versus $\$ 0.10 / \mathrm{W}$ in the United States). ${ }^{17}$ On a capacity-weighted average basis, soft costs constitute $39 \%$ of Japanese PV system price versus $66 \%$ of U.S. system price. Figure 19 shows component price differences between U.S. and Japanese commercial systems.

We focus on commercial systems of $10-50 \mathrm{~kW}$ because relatively few larger commercial systems are being installed in Japan. At the 50-kW level, Japanese requirements for engineering labor and interconnection applications increase significantly. In addition, the relatively small size of many Japanese businesses cannot support larger systems.

\footnotetext{
${ }^{16}$ All Japanese capacity-weighted averages were calculated based on the actual average system size for residential systems of a given installer, not an assumed system size.

${ }^{17}$ As in the residential section, these soft cost components are compared based on 1H13 values for Japan and 1 H12 values for the United States.
} 


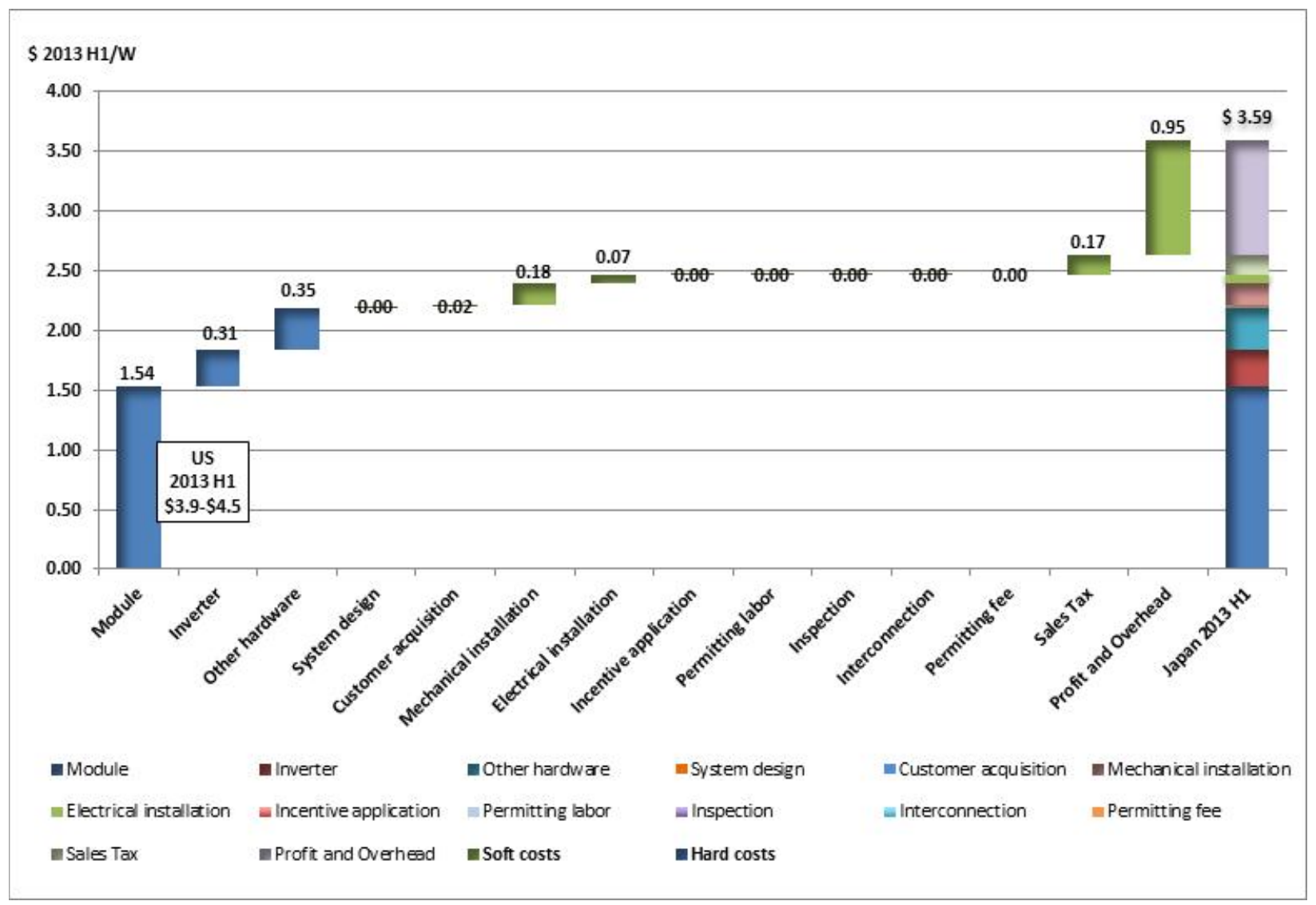

Figure 18. Components of Japanese small commercial (10-50 kW) PV system price in 1H13 


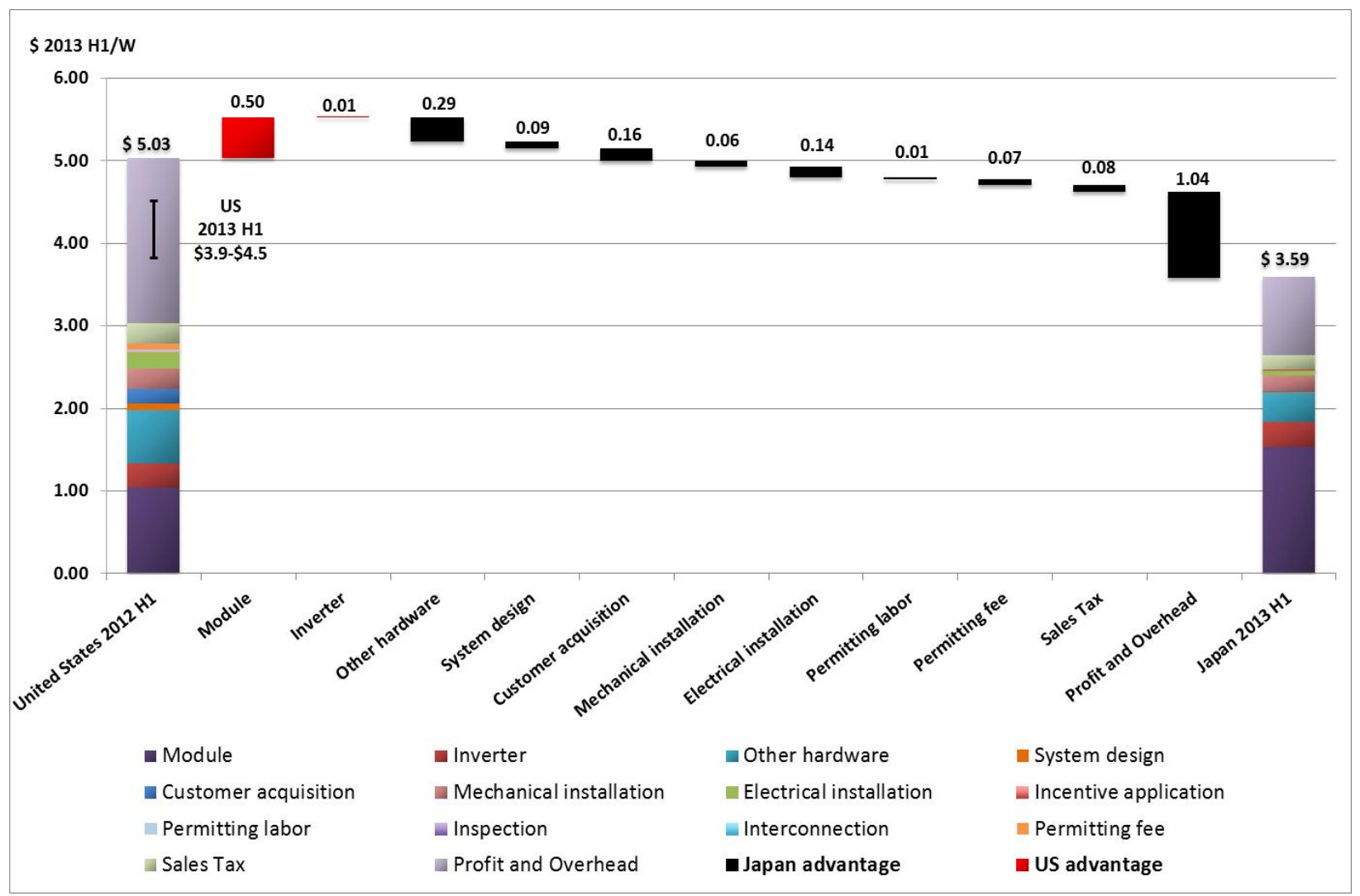

Figure 19. Price differences between U.S. (1H12) and Japanese (1H13) commercial systems

The following sections detail the Japanese commercial PV cost results from our interview data compared with U.S. costs. We compare Japanese commercial soft costs for 1H13 with U.S. commercial soft costs for the half-year period 1 year earlier (1H12) because $1 \mathrm{H} 12$ is the most recent period for which detailed U.S. primary data are available As Figure 20 shows, the resulting comparisons are meaningful because U.S. soft costs changed little between 2012 and 2013 (i.e., hardware cost reductions drove the decline in U.S. system price during that period). 


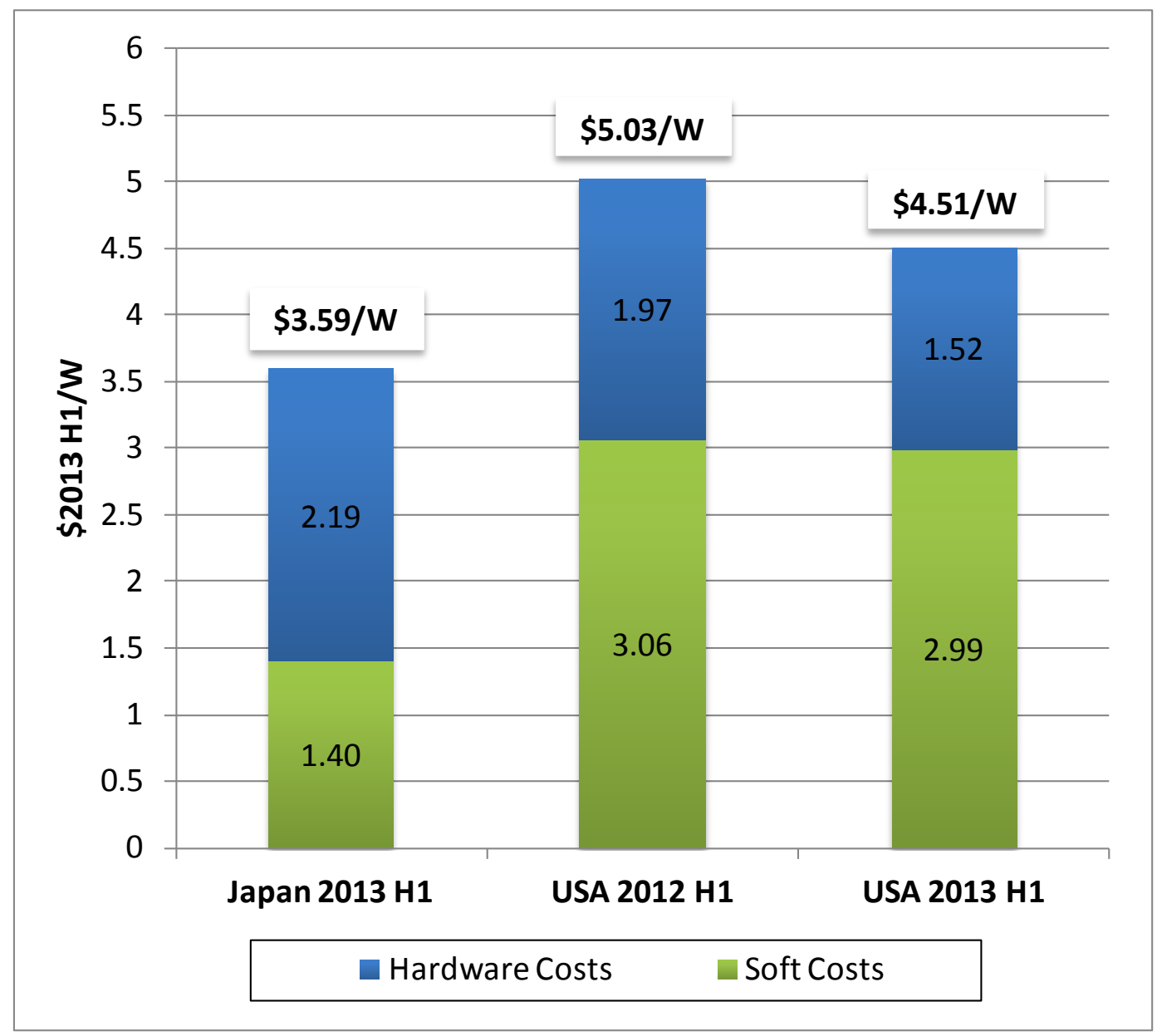

Figure 20. Comparison of total commercial PV system hardware and soft costs among Japan (1H13), the United States in 1H12, and the United States in 1H13, showing that most of the decline in U.S. system price between 2012 and 2013 was due to hardware cost reductions

\subsection{Hardware}

Commercial PV hardware costs in Japan for $1 \mathrm{H} 13$ totaled $\$ 2.19 / \mathrm{W}$ (Figure 21). This is 11\% higher than U.S. hardware costs during $1 \mathrm{H} 12$ of $\$ 1.97 / \mathrm{W}$, and $44 \%$ higher than U.S. hardware costs during $1 \mathrm{H} 13$ of $\$ 1.52 / \mathrm{W}$. As discussed previously, the structures of the Japanese and U.S. PV markets and Japanese reliance on domestic brands drive this price differential. The business focuses of particular Japanese installers also influence hardware costs. Our data show that the average commercial hardware cost for installers who commit less than one third of their business activity to PV is $14 \%$ higher than the cost for those who commit one third to two thirds and $12 \%$ higher than the cost for those who commit more than two thirds. 


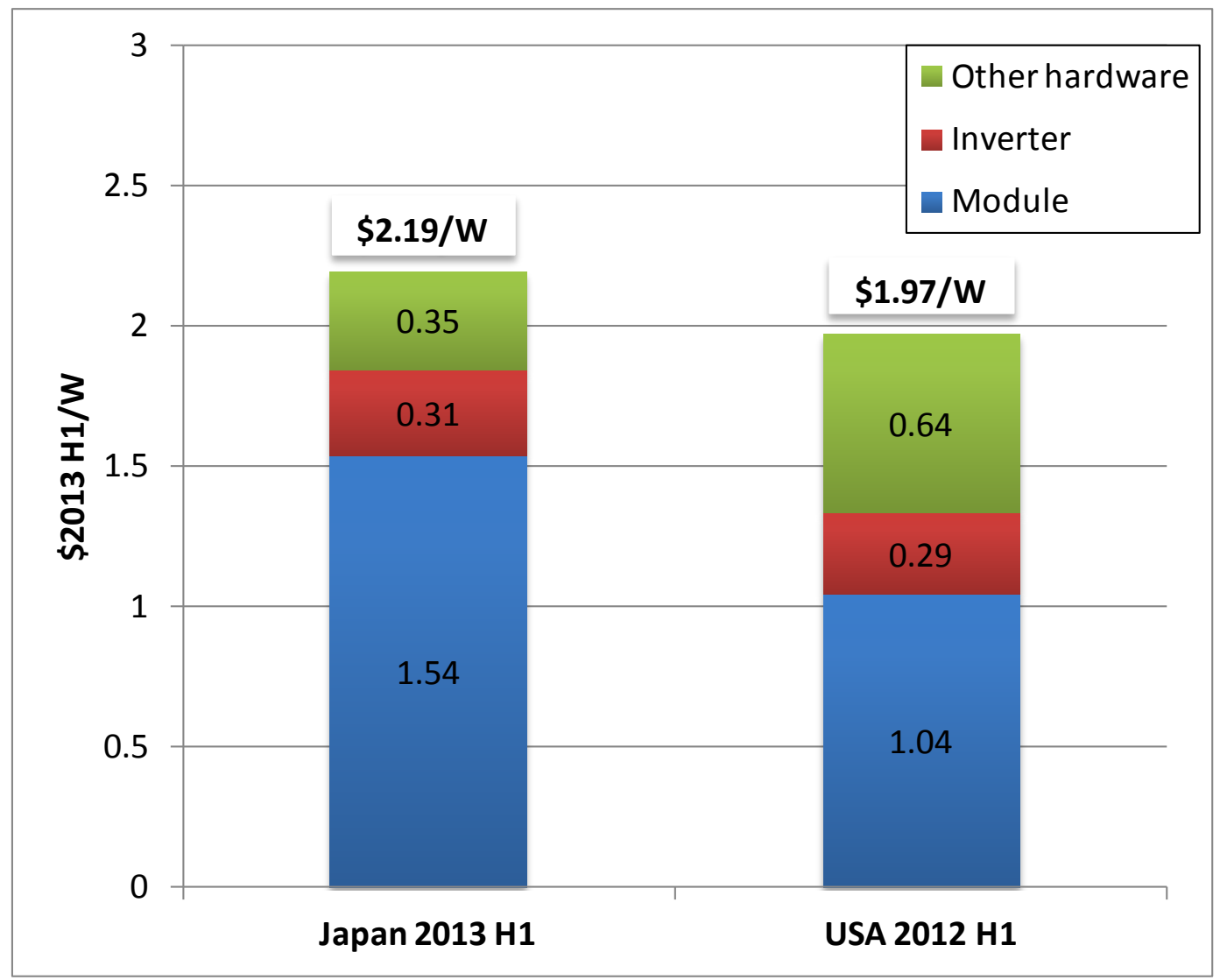

Figure 21. Japanese (capacity-weighted average, 1H13) and U.S. (1H12) commercial PV hardware costs (Friedman et al. 2013)

\subsection{Customer Acquisition and System Design}

Capacity-weighted average commercial customer-acquisition and system-design costs in Japan were $\$ 0.02 / \mathrm{W}$ in $1 \mathrm{H} 13$. This was $7 \%$ of the corresponding U.S. costs in $1 \mathrm{H} 12(\$ 0.27 / \mathrm{W})$. Figure 22 compares the two countries' costs.

The reasons for Japan's cost advantage for commercial systems are similar to the reasons for residential systems: perceived strong project economics, customer loyalty, and the ability to sell PV to existing non-PV customers slash the cost of acquiring new customers. In fact, our data show that the average customer-acquisition and system-design cost is very low $(\$ 0.01 / \mathrm{W}-$ $\$ 0.03 / \mathrm{W}$ ) for Japanese commercial installers regardless of how much of their business activity is committed to PV.

We interviewed several residential installers in Japan who had begun exploring the commercial market since the FiT started. Some had begun by building commercial installations on their own property, which provided direct economic benefits while serving as sales tools for prospective commercial customers. These installers typically had hourly performance data readily available on iPads or laptops to demonstrate daily and seasonal energy production to prospective customers. 
Finally, Japanese per-watt system-design costs for commercial systems are even lower (near zero) than for residential systems. This is because installers can leverage the standardized design software over the larger capacity of commercial systems.

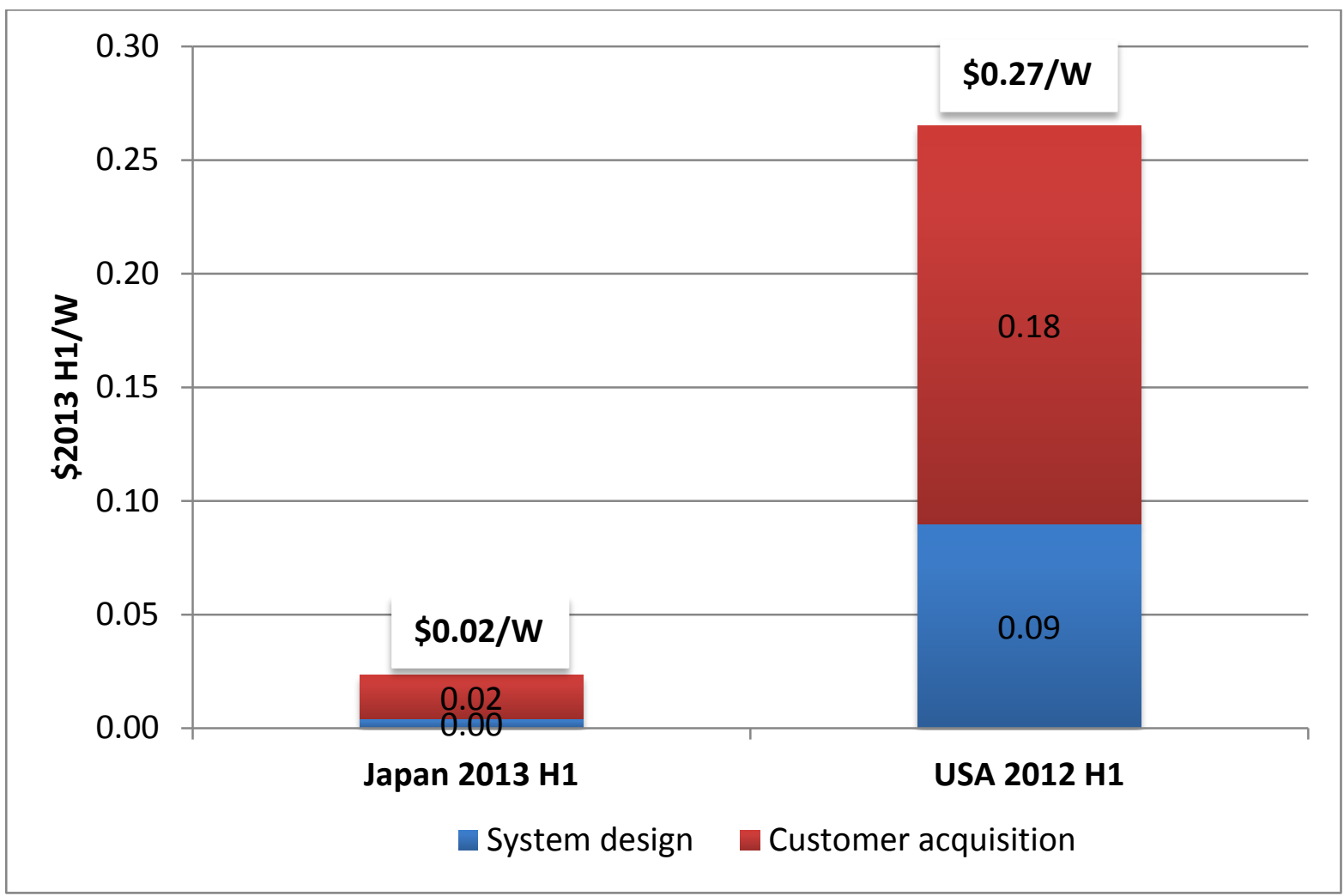

Figure 22. Japanese (1H13) and U.S. (1H12) commercial PV customer-acquisition and systemdesign costs (capacity-weighted averages)

\subsection{Installation Labor}

Capacity-weighted average commercial labor costs in Japan were $\$ 0.25 / \mathrm{W}$ in $1 \mathrm{H} 13$, compared with $\$ 0.45 / \mathrm{W}$ in the United States in 1H12 (Figure 23, Friedman et al 2013). Japanese installers also required about 1 hour less per kilowatt of PV installed. This Japanese commercial cost advantage contrasts with the residential disadvantage described in Section 4.3. The commercial results are more intuitive given significantly lower Japanese commercial wage rates (Figure 16) and the labor-saving promise of PV kits over individually installed hardware components. In addition, Japan's relative lack of suburban sprawl can reduce commute times for local installers. 


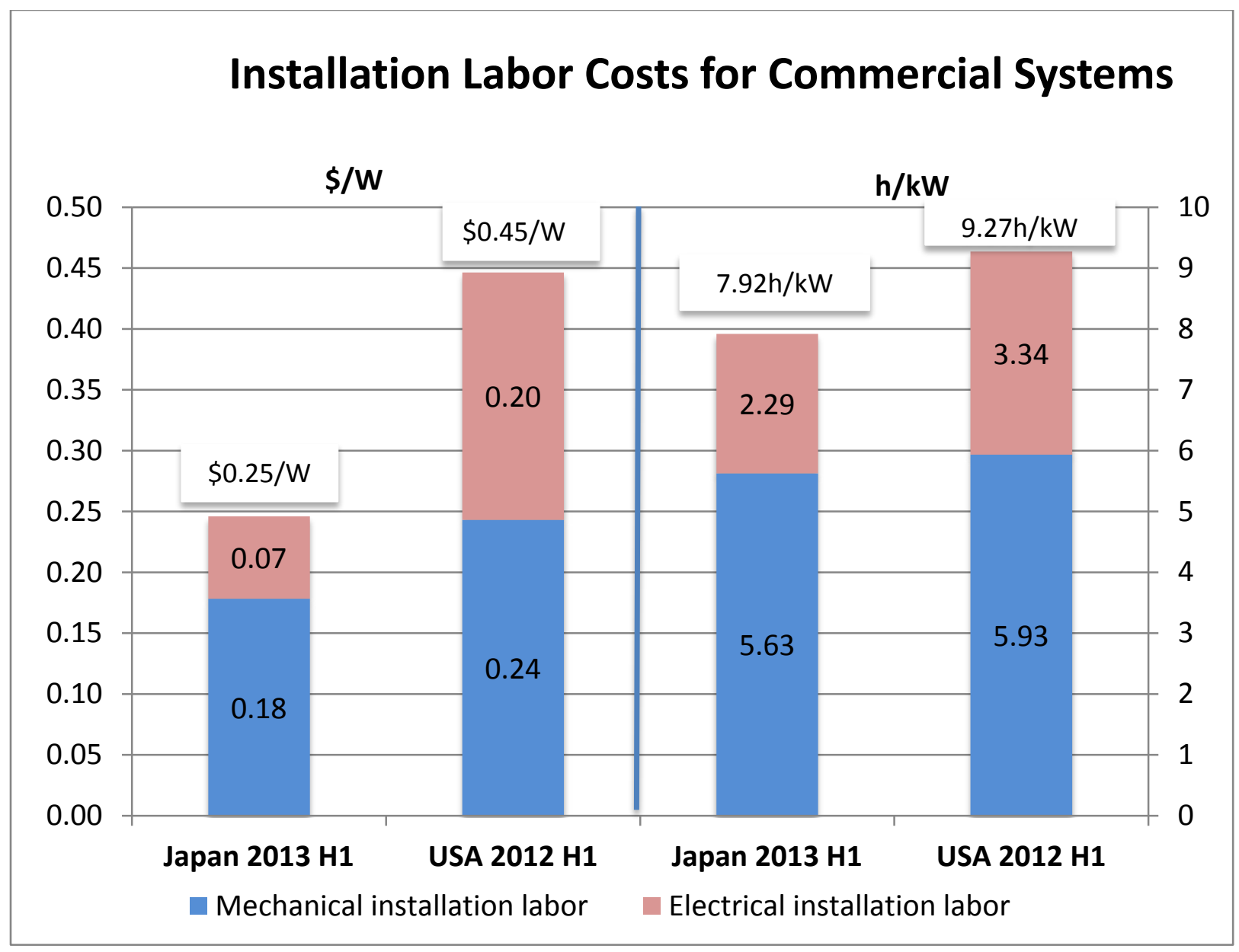

Figure 23. Japanese (1H13) and U.S. (1H12) commercial PV installation-labor costs and time requirements

Sources for U.S. data: Friedman et al. (2013), RSMeans (2010)

As with the residential installation-labor figures, we derived the Japanese and U.S. commercial labor costs differently. For the U.S. figures, we multiplied surveyed installer-specific labor times by an industry-average wage rate to yield labor costs. This is why U.S. residential and commercial labor wage rates are the same (Figure 16). We derived the Japanese figures from surveyed installer labor times and from surveyed installer wage rates, thus we have direct data for both of these metrics in Japan and do not rely on an industry average as we do for the United States.

\subsection{Permitting, Inspection, and Interconnection}

Capacity-weighted average commercial PII costs in Japan were \$0.01/W in 1H13 compared with $\$ 0.10 / \mathrm{W}$ in the United States in 1H12 (Figure 24). Installers in the United States also required about 1 additional PII-related labor hour per kilowatt installed.

The main reason for Japan's advantage is its more uniform requirements, which stem from the market control maintained by domestic PV kit manufacturers. Having relatively few types of kits helps ensure quality control and consistency. In addition, Japanese installers cannot afford to 
have systems with structural or electrical problems because they are so heavily invested in customer relationships (which is similar to the situation in Germany). In Japan, installers are not required to be present during final utility inspections. Conversely, electricians registered with their utility can carry out their own final inspection prior to interconnection, without having to wait for a utility representative. Incentive application costs in Japan are much lower for commercial systems than for residential systems on a per-watt basis because similar fixed costs are spread over larger system sizes.

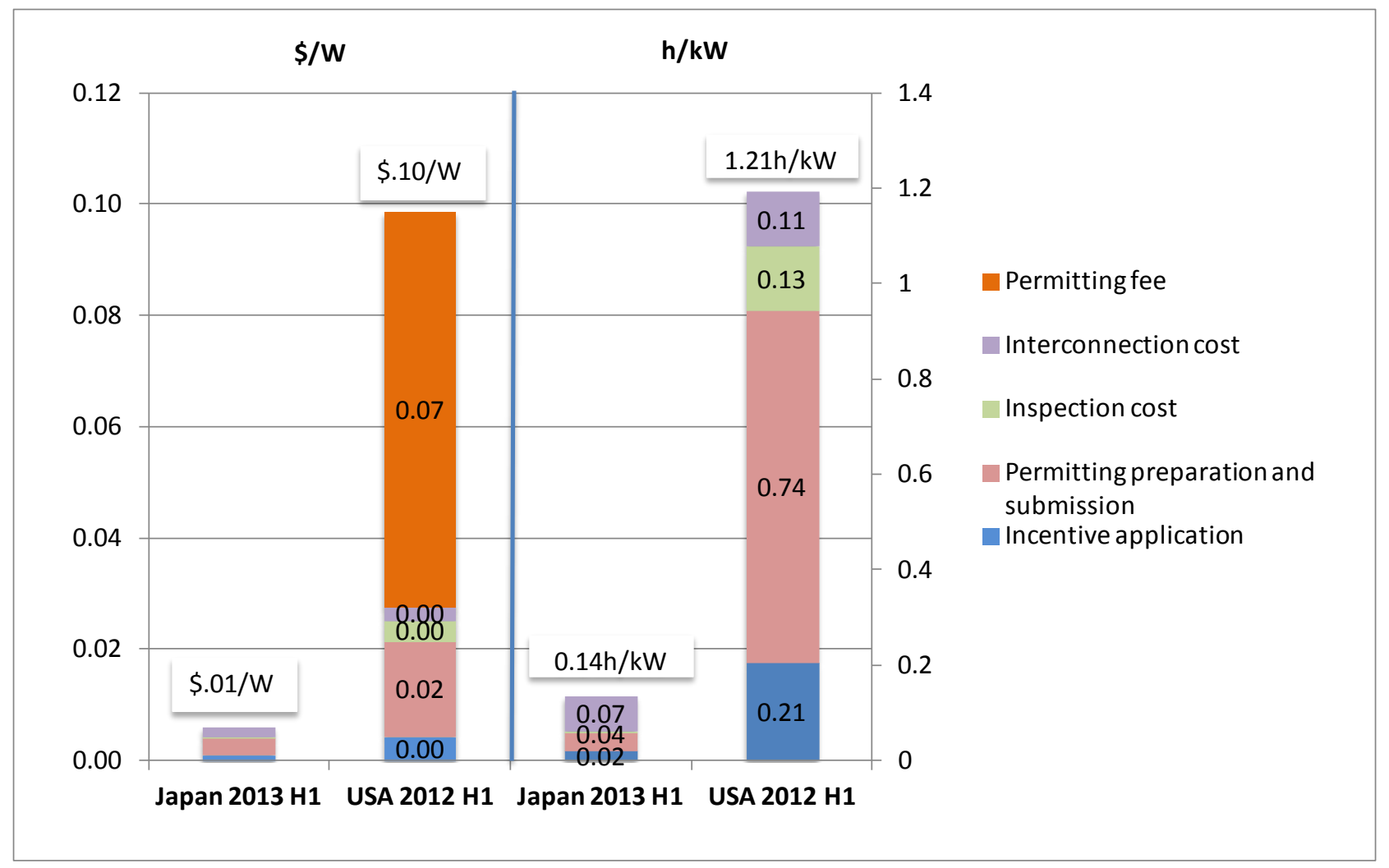

Figure 24. Japanese (1H13) and U.S. (1H12) commercial PV PII costs and time requirements

\section{Incentives and Policy: Lessons for the United States}

As discussed in Section 3.3, Japan's three major PV policy initiatives have driven the country's PV growth: the FiT, the national cash subsidy, and the more than 900 local incentives. This section analyzes the impacts of the FiT and the national cash subsidy to explore whether elements of such policies might benefit the U.S. PV market. ${ }^{18}$ In Japan, the economics of these policies have made PV attractive to many consumers and driven rapid PV growth.

\footnotetext{
${ }^{18}$ Because of the complexity and heterogeneity of local incentives, we do not focus on the impacts of these incentives.
} 


\subsection{FiT Policy}

The FiT policy requires electric utilities to enter into power-purchase agreements with renewable energy producers. The utilities recoup their costs through customer surcharges; large industry customers can apply for exemptions to avoid these surcharges. Via the FiT, the government targets a $3.2 \%$ annual return on residential systems and a $6 \%$ return on commercial systems (Yamaya et al. 2013). Discussions with installers indicate that returns for commercial systems have typically been much higher than that. The FiT requires module efficiencies to exceed 13.5\% for crystalline silicon, $7.0 \%$ for amorphous silicon, and $8.0 \%$ for other thin films. These requirements also apply to building-integrated PV modules, but flexible and concentrator devices are excluded.

The FiT amounts were reduced for the new Japanese fiscal year, effective April 1, 2013, and can be reduced semiannually based on recommendations from an independent third-party committee organized by METI. A general review of the FiT and FiT levels is to be conducted every 3 years, with a full review in 2020. On April 1, the residential (less than $10 \mathrm{~kW}$ ) FiT was set at $\$ 0.40 / \mathrm{kWh}$ for surplus generation (electricity not consumed by the home). The commercial and mega solar (10 kW or greater) FiT was set at \$0.37/W for all electricity generated. The FiT term lengths are also different: 10 years for residential and 20 years for commercial and mega solar (METI 2013).

Table 2 shows the FiT values for Japanese fiscal years 2012 and 2013, in yen (¥) and dollar conversions. Throughout this section, nominal yen values were converted to inflation-adjusted 2013 dollars.

Table 2. FiT Values as of April 1, 2013

\begin{tabular}{|c|c|c|c|c|}
\hline \multirow[b]{2}{*}{$\begin{array}{l}\text { Fiscal } \\
\text { year }\end{array}$} & \multicolumn{2}{|c|}{$\begin{array}{c}<10 \mathrm{~kW} \\
\text { (for } 10 \text { years, excess electricity) }\end{array}$} & \multicolumn{2}{|c|}{$\begin{array}{c}\geq 10 \mathrm{~kW} \\
\text { (for } 20 \text { years, all electricity) }\end{array}$} \\
\hline & $\begin{array}{c}\text { FiT value } \\
(¥ \text { nom } / \mathrm{kWh})\end{array}$ & FiT value $(\$ 1 \mathrm{H} 13 / \mathrm{kWh})$ & FiT value (¥nom/kWh) & FiT value $(\$ 1 \mathrm{H} 13 / \mathrm{kWh})$ \\
\hline 2012 & 42 & 0.44 & 40 & 0.42 \\
\hline 2013 & 38 & 0.40 & 36 & 0.37 \\
\hline
\end{tabular}

Source: METI (2013)

\subsection{National Cash Subsidy}

The "Residential Solar Power Support Measure," or national cash subsidy program for systems smaller than $10 \mathrm{~kW}$, is administered by J-PEC on behalf of METI and has several unique features and requirements. To secure subsidies, owners of residential PV systems must obtain certification that demonstrates conformity with product standards set by the Japan Electrical Safety \& Environment Technology Laboratories or equivalent certification by an overseas certification body. To be eligible, module efficiencies must exceed minimum efficiency requirements: $16 \%$ for monocrystalline silicon, $15 \%$ for multicrystalline silicon, $8.5 \%$ for amorphous silicon, and 12\% for copper indium gallium (di) selenide (CIGS) and cadmium telluride (CdTe). In addition to operating under manufacturer IDs, to receive the national subsidy installers are restricted to installing modules registered with the Japanese PV Energy Association. 
The subsidy is relatively small. For Japanese fiscal year 2013, systems priced at or less than $\$ 4.10 / \mathrm{W}$ receive about $\$ 0.20 / \mathrm{W}$, while systems priced between $\$ 4.10 / \mathrm{W}$ and $\$ 5.00 / \mathrm{W}$ receive $\$ 0.15 / \mathrm{W} .{ }^{19}$ Systems priced higher than $\$ 5.00 / \mathrm{W}$ cannot receive a cash subsidy. By providing price ceilings for eligibility, the national cash subsidy offers an interesting contrast with U.S. policy. Arguably, the United States has incentivized higher and not lower system prices through the $30 \%$ investment tax credit, which returns $30 \%$ of the system price in the form of a tax credit to installers.

\subsection{Net Present Value and Rate of Return Models}

To better understand the economic value of Japanese PV systems, we modeled both the net present value (NPV) of systems and the expected rates of return on systems under the FiT and national cash subsidy policies. We found that residential PV systems do not produce the same level of returns that commercial systems do because of two key attributes of the residential FiT. First, it is available for only the first 10 years of the system lifetime, instead of the 20-year commercial and mega solar FiT periods. Second, it applies only to surplus electricity (electricity generated in excess of the amount consumed by the household over a given period), which is often only a small fraction of the electricity produced by the system. During the 10-year FiT period, local incentives increase economic returns as well. These vary depending upon the city or prefecture. With the guaranteed 20-year FiT price for all electricity generated, commercial and mega solar economics are much more advantageous.

\subsubsection{Financial Models for Residential Systems in Japan}

Residential PV systems are expected to deliver economic benefit for approximately 15-20 years after the FiT period expires, although the policy and therefore the economic returns for these out years are unknown. However, it seems likely that solar electricity will continue to be valued following the 10-year FiT, either through extensions of current net-metering agreements or via some form of a premium over the other wholesale market prices during the time of generation. We modeled a "middle ground" scenario for a family with medium electricity consumption and a typical 5-kW system purchased at an average price, receiving median national insolation values. We assume a 25-year life span of the system and hypothesize a continued net-metering agreement for years 11-25 that values PV excess generation at the retail electricity priceapproximately $\$ 0.24 / \mathrm{kWh}^{20}$ In this scenario, the homeowner would receive the FiT value for excess generation in years $1-10$, with continued net metering in years $11-25$, plus revenue from excess generation during this period. This scenario yields an NPV for the system of $\$ 1,892$ and a rate of return (RoR) of $8 \%$. However, these returns would be significantly lower with a lower price for excess generation, lower insolation, or a higher PV system price. In addition, electricity consumption can significantly affect NPV and RoRs, depending on the policy put in place for

\footnotetext{
${ }^{19}$ Based on currency conversions for $1 \mathrm{H} 13$ (Federal Reserve 2013).

${ }^{20}$ The base scenario employs the following assumptions:
}

- Set electricity price $-\$ 0.24 / \mathrm{W}$, the simple average of the range provided by TEPCO of $\$ 0.19-\$ 0.29 / \mathrm{kWh}$

- $\quad$ System price of $\$ 4.64 / \mathrm{W}$

- $\quad$ Electricity consumption of 3,600 kWh/year

- Insolation of $1,306 \mathrm{kWh} / \mathrm{m}^{2}$ global horizontal, which represents the approximate median of nine cities in Japan in the System Advisor Model (SAM)'s International Weather database, chosen because they were available in SAM and, by covering major metropolitan areas, fairly represent Japan overall. 
years 11-25 following the FiT. This substantial sensitivity to various parameters is reflected in Figure 25 and Figure 26 and in the models in Appendix B.

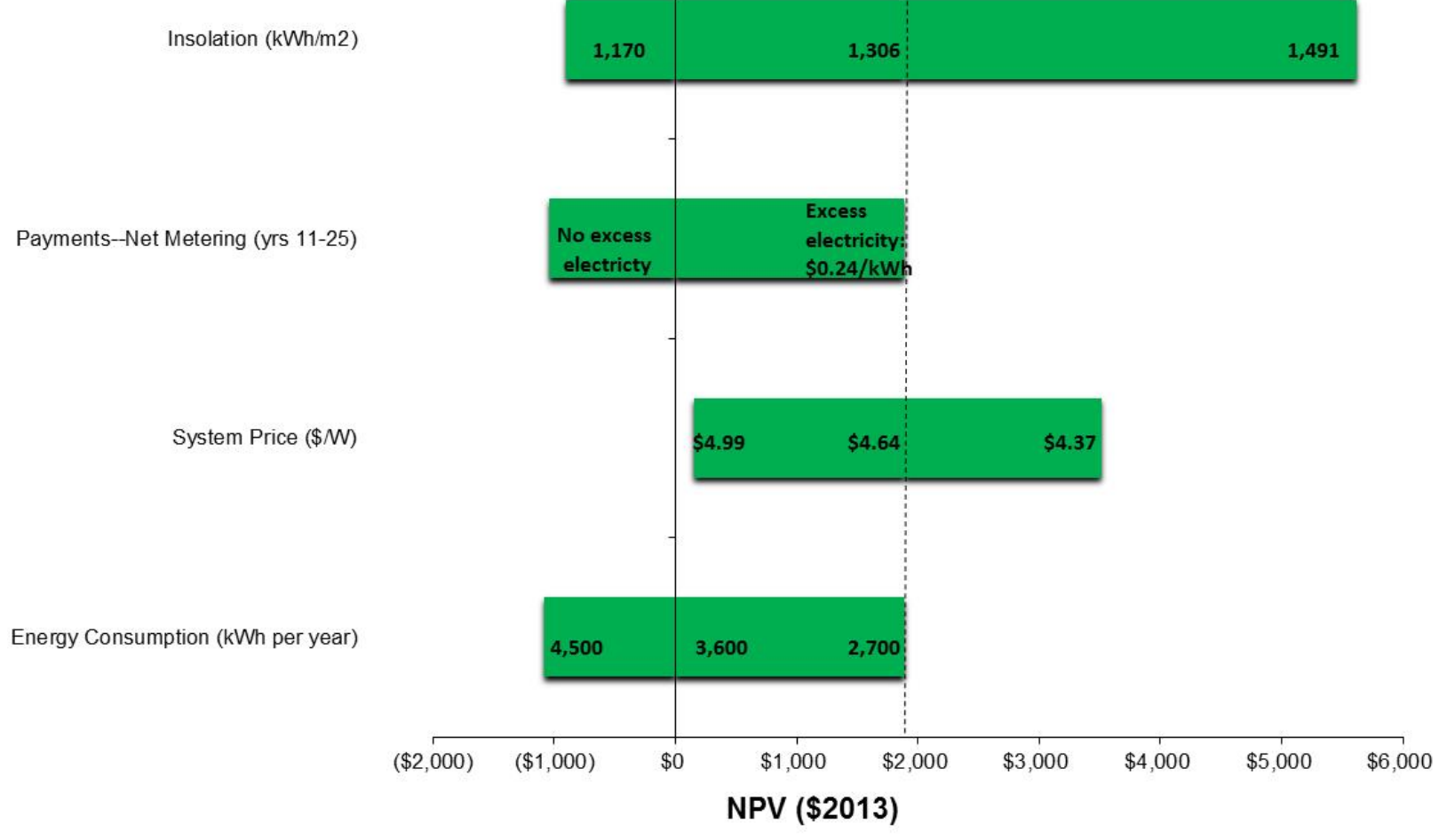

Figure 25. Sensitivity of modeled Japanese residential PV system NPV to changes in parameters 


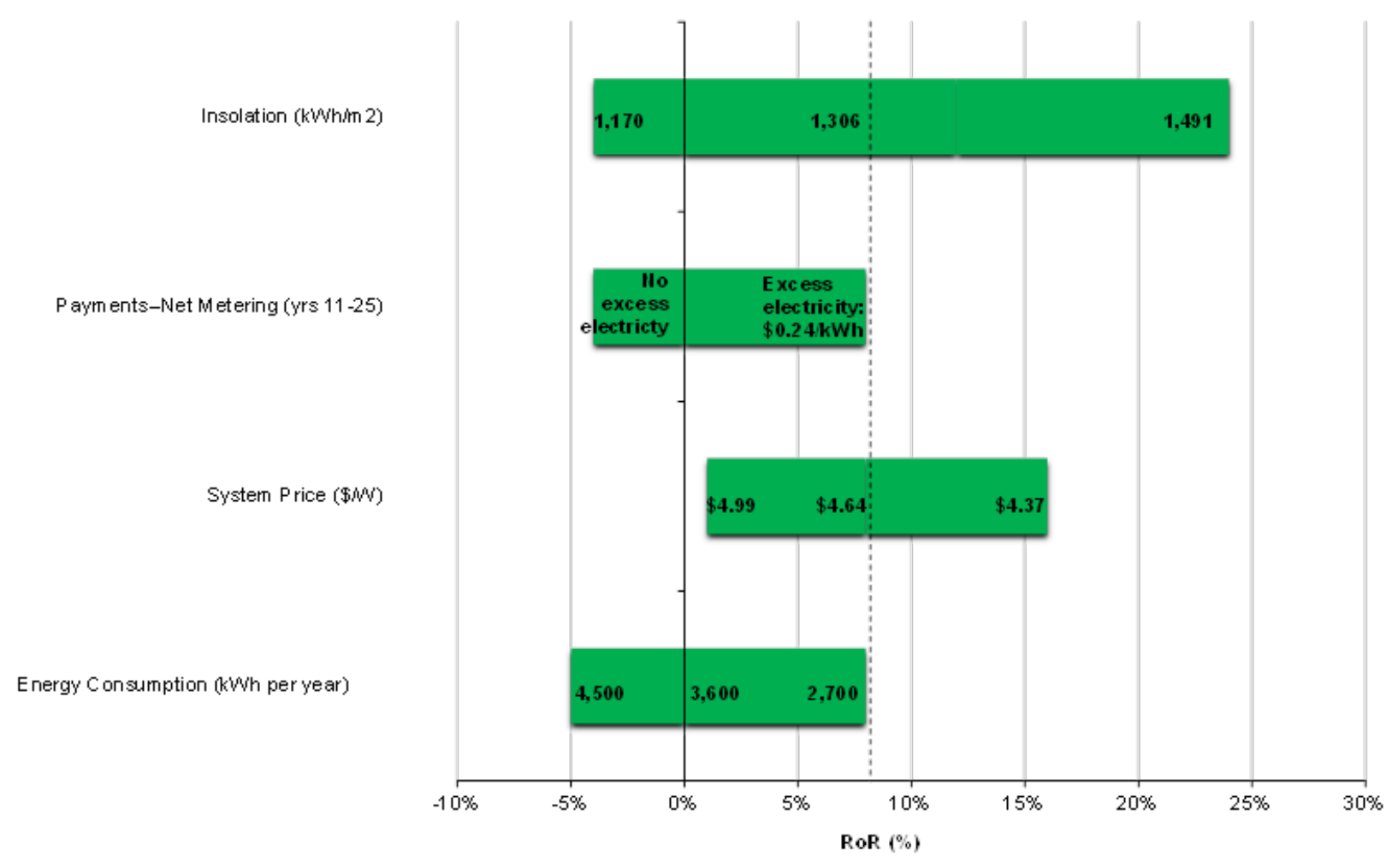

Figure 26. Sensitivity of modeled Japanese residential PV system RoR to changes in parameters

\subsubsection{Financial Models for Commercial Systems in Japan}

For commercial systems, electricity consumption and payment schedule do not come into play as they do for residential systems because of the commercial FiT structure. In a base scenario assuming a system size of $50 \mathrm{~kW}$, insolation of $1,306 \mathrm{kWh} / \mathrm{m}^{2}$, and system price of $\$ 3.59 / \mathrm{W}$, our model shows an NPV of $\$ 129,103$ and an RoR of 74\% for the 20-year commercial FiT. As shown in Figure 27 and Figure 28, these results are affected by insolation and system price assumptions, but returns remain high under all the scenarios we modeled. 


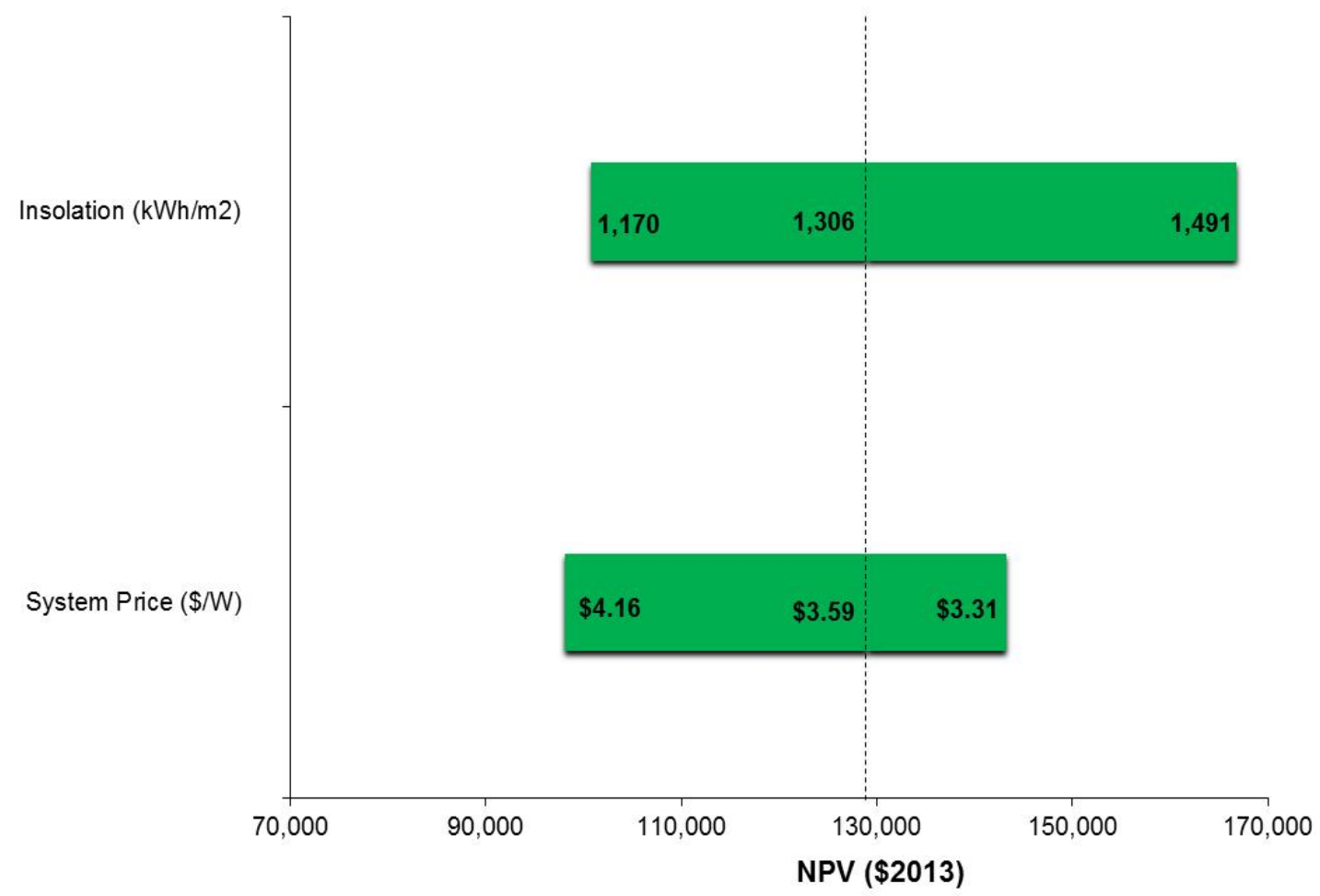

Figure 27. Sensitivity of modeled Japanese commercial PV system NPV to changes in parameters 


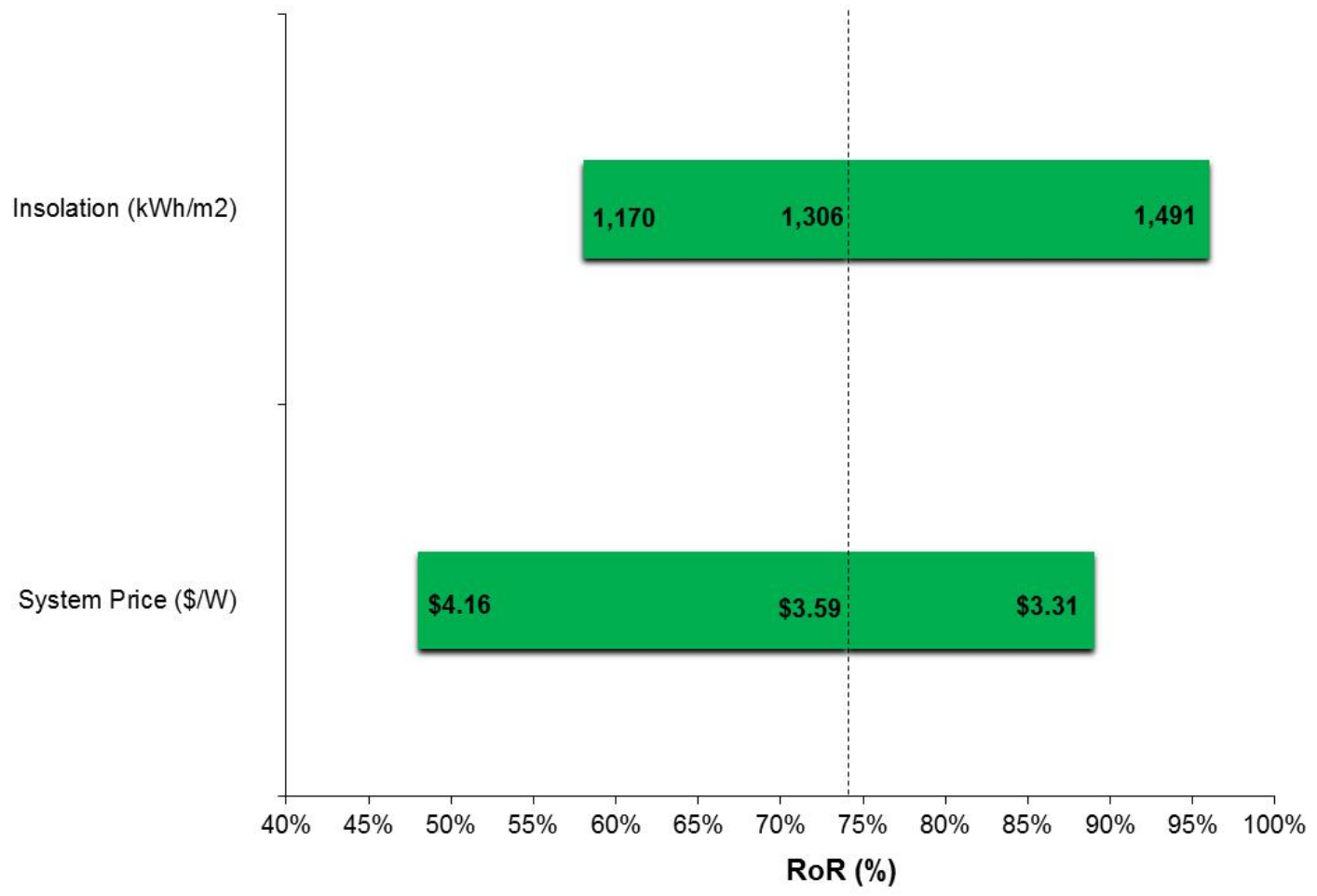

Figure 28. Sensitivity of modeled Japanese commercial PV system RoR to changes in parameters

\section{Conclusions}

This report explores why PV is economically attractive in Japan and thus is experiencing rapid growth. The interplay between Japan's PV market and energy policies - which have similarities with the U.S. market and policies but also major differences - drives the country's PV economics. In addition to providing insight into an important global PV market, understanding Japan's strategies illuminates challenges and opportunities for the growing U.S. PV market.

Installed system price is a major driver of PV economics, and the increased sales volumes and competition stimulated by Japan's energy policies are among the many factors determining system price. Although non-module hardware costs are lower in Japan, Japan's substantially higher module costs make its total hardware costs higher than U.S. costs. Japanese module prices are higher because its consumers and installers prefer domestic brands, which are more expensive than the global average module, and Japan's complex module distribution network incurs additional supply-chain costs. However, as Japan's PV policies boost module demand and encourage price reductions, the dominance of its domestically produced modules and the distribution system controlled by domestic manufacturers are waning. The entrance of cheaper foreign modules - as well as pure-play PV installers choosing the lowest-cost options-likely will push Japanese module costs downward.

In part because of Japan's higher hardware costs, soft costs account for a smaller proportion of system price in Japan than in the United States. Soft costs constitute $44 \%$ of residential PV system prices in Japan versus $67 \%$ in the United States, and they constitute $39 \%$ of Japanese commercial system prices versus $66 \%$ of U.S. prices. Figure 29 displays the soft costs analyzed 
in this report, showing Japan with a $\$ 0.16 / \mathrm{W}$ lower cost in the residential sector and a $\$ 0.53 / \mathrm{W}$ lower cost in the small commercial sector. ${ }^{21}$ In each case these costs constitute only part of total soft costs. For residential PV, soft costs not shown in this figure amount to $\$ 1.05 / \mathrm{W}$ for Japan and $\$ 2.22 / \mathrm{W}$ for the United States. For commercial, they amount to $\$ 1.12 / \mathrm{W}$ for Japan and $\$ 2.25 / \mathrm{W}$ for the United States. These non-analyzed soft costs include operating profit and sales tax.

Among the soft costs we examined, customer acquisition and system design account for the largest difference between Japanese and U.S. costs. Japanese costs are $\$ 0.23 / \mathrm{W}$ lower in the residential sector and $\$ 0.25 / \mathrm{W}$ lower in the small commercial sector (comparing $1 \mathrm{H} 13$ Japanese costs with 1H12 U.S. costs). In both sectors, customer acquisition is eased by Japanese installers' preexisting relationships with customers through other business lines and by the attractive policy-driven economics and public support that enable PV to "sell itself." Japan's systemdesign costs also are a fraction of U.S. costs because installers there use standardized design programs produced by major Japanese module manufacturers, resulting in typical design times of less than an hour. Cross-selling PV within non-PV industries, increasing the economic attractiveness of $\mathrm{PV}$, and standardizing the PV system-design process all represent potential costreduction opportunities for U.S. companies and policymakers.

\footnotetext{
${ }^{21}$ As discussed previously, we must compare 1H13 Japanese soft costs with 1H12 U.S. soft costs because of data availability, but this comparison is meaningful because total U.S. soft costs declined little between 2012 and 2013.
} 


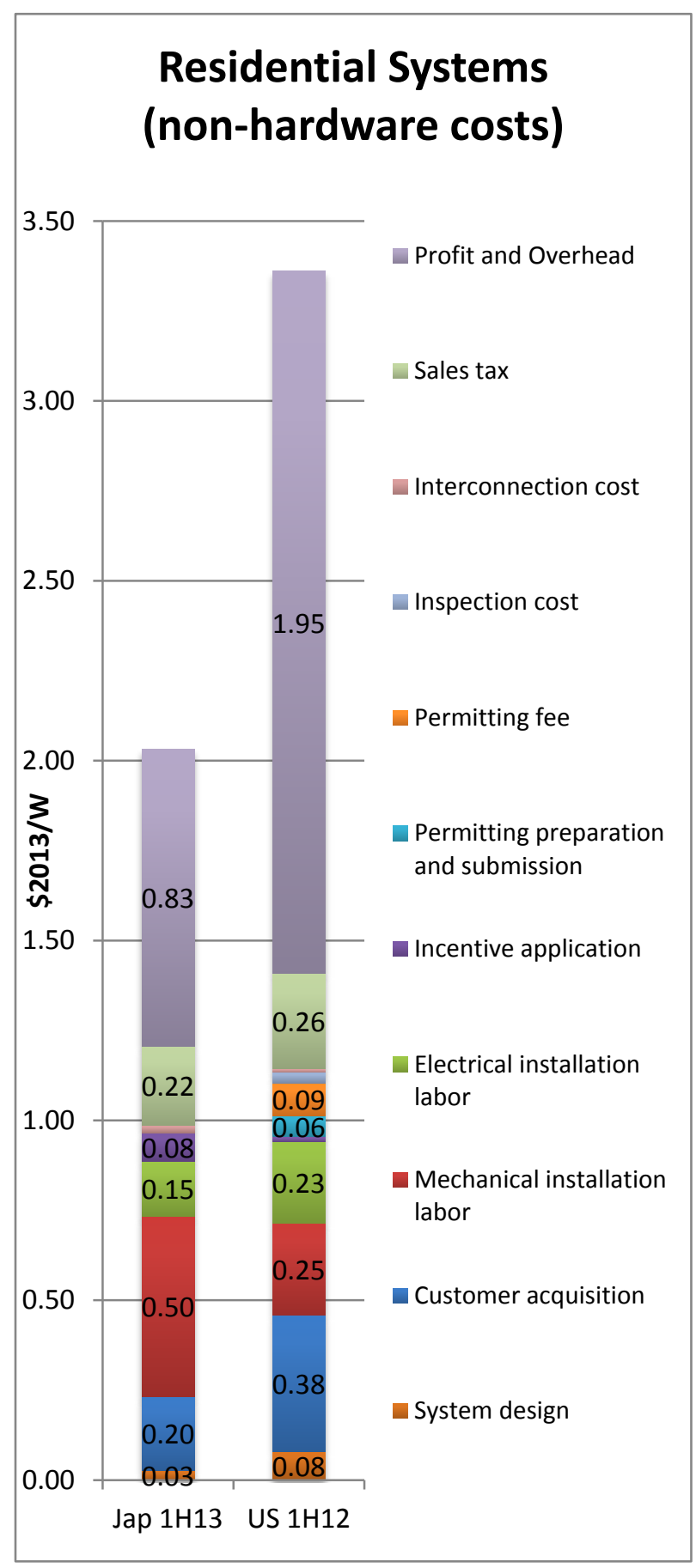

\section{Small Commercial Systems (non-hardware costs)}

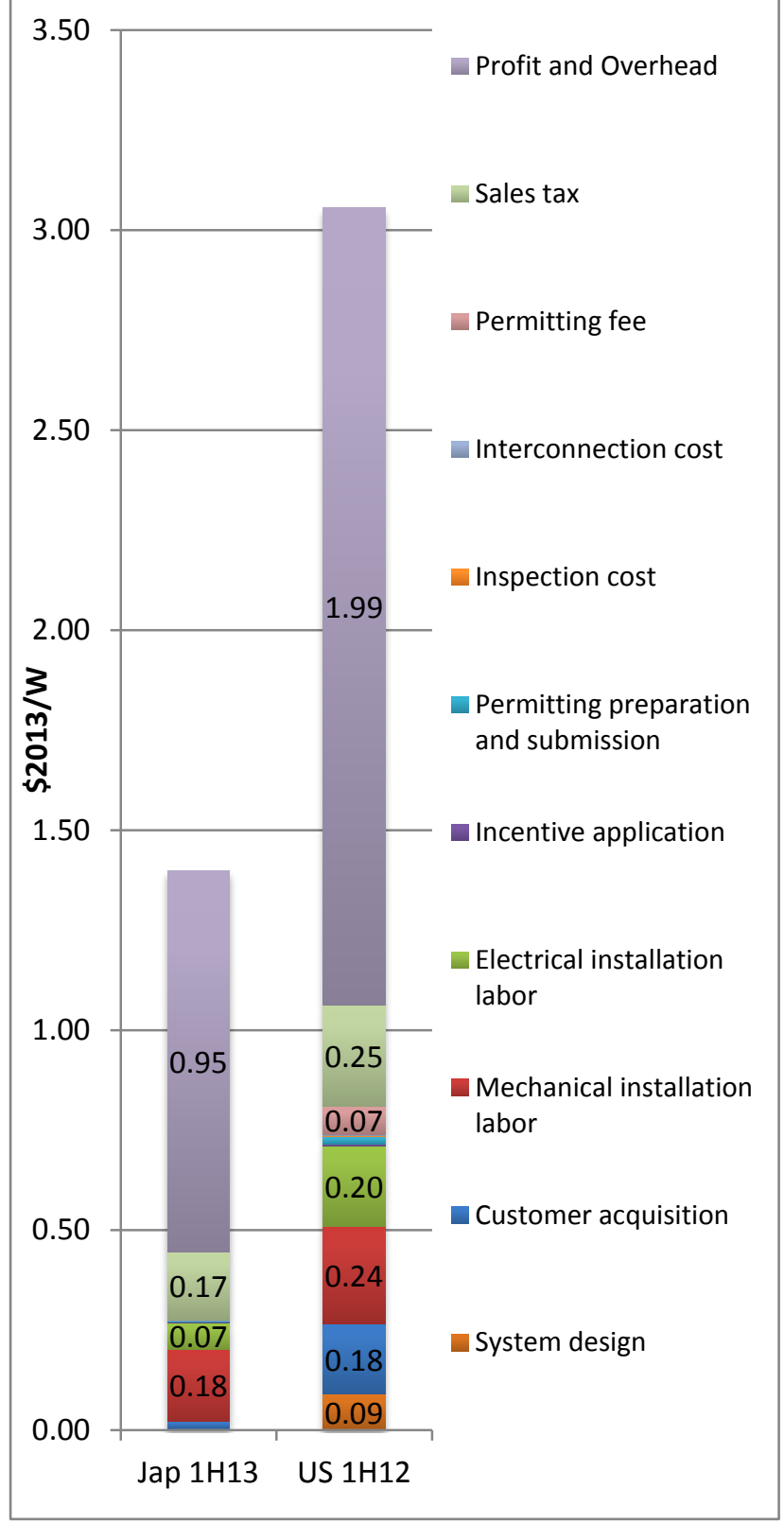

Figure 29. Japanese (1H13) and U.S. (1H12) PV non-hardware costs analyzed in this report: residential (left) and small commercial (right)

Source for U.S. data: Friedman et al. (2013)

Comparative PV installation-labor costs tell an ambiguous story. Japan's use of turnkey PV kits - which are much more prevalent there than in the United States - should cut installationlabor times and costs. In the residential sector, however, Japanese installation-labor costs are 
\$0.17/W higher than U.S. costs (comparing 1H13 Japanese costs with 1H12 U.S. costs). Apart from a $15 \%$ lower average hourly wage for U.S. roofers (offset by a $90 \%$ higher electrician wage), the reasons for this are unclear. Differences in the countries' typical residential roofing materials could play a role as well as different allocations of mechanical and electrical labor in each country. In the commercial sector, the cost differential is more intuitive, with Japan apparently reaping the benefits of its PV kits (along with lower mechanical and electrical wage rates in the commercial sector) for a $\$ 0.20 / \mathrm{W}$ cost advantage. Also, Japan's commercial roofs, unlike its residential roofs, are often not tiled, in which case the mechanical work is likely more streamlined. Japan's lower incidence of suburban sprawl might also reduce installation-labor costs owing to shorter commute times.

Finally, Japan's PII costs are $\$ 0.10 / \mathrm{W}$ lower in the residential sector and $\$ 0.09 / \mathrm{W}$ lower in the commercial sector (comparing 1H13 Japanese costs with 1H12 U.S. costs). Unlike U.S. installers, Japanese installers incur negligible permitting fees, permitting preparation and submission costs, and inspection costs. Installers and policymakers in the United States might see Japan's streamlined regulatory processes - as well as the high level of standardization and quality control that make them possible — as an additional cost-reduction opportunity.

In conjunction with installed system prices, aggressive energy policies are driving Japan's rapid PV growth. The FiT, the national cash subsidy, and local incentives - and the ability to combine the benefits of these policies - have increased PV's attractiveness to Japanese consumers. We modeled the economic return due to the FiT and national cash subsidy. We found that residential owners of 5-kW PV systems in our base case might expect an RoR of $8 \%$ and an NPV of $\$ 1,892$. These returns, however, are sensitive to insolation, post-FiT PV payments, system price, and energy consumption assumptions. Lower insolation, or a lack of excess-electricity payments in years 11-25 of the PV system's lifetime could result in a negative RoR for residential PV. Commercial PV, on the other hand, receives more generous terms than does residential PV under Japan's FiT, and our modeled commercial returns are highly favorable under a range of assumptions: our base case has an NPV of $\$ 129,103$ and an RoR of $74 \%$, and these never drop below about $\$ 100,000$ and $48 \%$ under the assumptions we modeled. The differential FiT returns among sectors are helping shift Japan's PV deployment toward commercial and mega solar systems. 


\section{References}

Alfsen, J. "Tile Roofing Systems: Materials and Methods for Flashing Penetrations," (2011), Solar Pro Magazine, Issue 4.1, accessed December 4, 2013.

Barbose, G.; Darghouth, N.; Wiser, R. (2013). Tracking the Sun VI: An Historical Summary of the Installed Cost of Photovoltaics in the United States from 1998 to 2012. Berkeley, CA: Lawrence Berkeley National Laboratory.Burger, S. (2012). "The Japan PV Market, 2012-2016: A New Era of Solar or the Beginning of a Boom-Bust Cycle?” Boston, MA: Greentech Media Research.

Bloomberg New Energy Finance "Generation Capacity” Market Size Tool. www.bnef.com. Accessed April 10, 2014.

Chase, J. “PV Market Outlook, Q1 2014.” Bloomberg new Energy Finance. February 17, 2014.

EIA (U.S. Energy Information Administration). (2013). Japan analysis.

http://www.eia.gov/countries/analysisbriefs/Japan/japan.pdf, accessed October 20, 2013.

Federal Reserve, "Foreign Exchange Rates - H.10, Historical Rates for the Japanese Yen," http://www.federalreserve.gov/releases/h10/hist/dat00 ja.htm, accessed September 9, 2013.

Feldman, D.; Barbose, G.; Margolis, R.; Wiser, R.; Darghouth, N.; Goodrich, A. (2012). Photovoltaic (PV) Pricing, Trends: Historical, Recent, and Near-Term Projections. NREL Report No. DOE/GO-102012-3839. Golden, CO: National Renewable Energy Laboratory.

Friedman, B.; Ardani, K.; Feldman, D.; Citron, R.; Margolis, R.; Zuboy, J. (2013).

Benchmarking Non-Hardware Balance-of-System (Soft) Costs for U.S. Photovoltaic Systems, Using a Bottom-Up Approach and Installer Survey - Second Edition. NREL Report No. TP6A20-60412. Golden, CO: National Renewable Energy Laboratory.

GTM/SEIA (Greentech Media Research/Solar Energy Industries Association). (2013). U.S. Solar Market Insight Report 2012. Washington, DC: Solar Energy Industries Association.

Hill, S.J. (2013). "Japanese Solar Industry Soaring.” Cleantechnica, http://cleantechnica.com/2013/06/04/Japanese -solar-industry-soaring/, accessed June 2013.

James, T.; Feldman, D.; Margolis, R. (2014). Japan's Solar Photovoltaic (PV) Market: An Analysis of Residential System Prices. NREL Report No. PR-6A20-60419. Golden, CO: National Renewable Energy Laboratory.

Japanese Photovoltaic Energy Association (JPEA, 2013). “Quarterly Module Shipment Information, FY2012, FY2013Q1, accessed November 2013.

Lee, B; Daniels, T; Boril, Britt. "Sell-off provides a better entry point - Remain Attractive on Solar.” Goldman Sachs Equity Research. April 10, 2014. 
METI (Japanese Ministry of Economy, Trade, and Industry). (2013). "Present Status and Promotion Measures for the Introduction of Renewable Energy in Japan."

http://www.meti.go.jp/english/policy/energy environment/renewable/, accessed October 15, 2013.

Meza, E. (2013). "Japan to Offer Loans for Rooftop PV Generation.” PV Magazine, http://www.pv-magazine.com/news/details/beitrag/japan-to-offer-loans-for-rooftop-pvgeneration 100011441/\#axzz2VpfUhNTj, accessed June 2013.

Mints, P. (2013). Photovoltaic Manufacturer Shipments, Capacity, \& Competitive Analysis (2011/12). Palo Alto, Ca: Navigant Consulting Photovoltaic Service Program. Report \#NPSSupply7.

Movellan, J. (2013). "New Solar Homes: Japanese Homebuilders Helping the Fight for Energy Independence." Renewable Energy World, http://www.renewableenergyworld.com/rea/news/article/2013/07/new-solar-homes-japanesehomebuilders-helping-the-fight-for-energy-independence, accessed March 2014.

Nick, J.; Calhoun, K.; Morris, J. (2013). "Simple BOS Residential Survey, Preliminary Results." Boulder, CO: Rocky Mountain Institute.

Nobuoka, Y. (2014). “Japan - Analyst Reaction.” Bloomberg New Energy Finance, April 16, 2014.

O’Rorke, F., (2013). “Trouble Up North a Warning Sign of Japanese Gridlock. Cleanbiz.Asia. Accessed January 22, 2014: http://www.cleanbiz.asia/tags/hokkaido-electric-power.

Osborne, Jeffrey; Eenmaa, Sven. "2014 Outlook: Several Favorable Secular Megatrends for Industrials/Cleantech.” Stifel Research Department. January 3, 2014.

PHOTON Consulting, personal communications with Joe Lara, Ravi Manghani, David Southwick, and Nana Hari, March-December 2013.

PV-Tech. (2013). "Japan to exclude net-metering from new FiT." PV-Tech, http://www.pvtech.org/, accessed September 2013.

Renewable Energy World. (2013). “Asia Report: Japan’s Solar Market Shifts into Overdrive.” Renewable Energy World, http://www.renewableenergyworld.com/rea/news/article/2013/06/asia-report-japans-solarmarket-shifts-into-overdrive, accessed June 2013.

RSMeans (2010). Building Construction Cost Data. Norwell, MA: Reed Construction Data. RTS Corporation. (2013). "PV Activities in Japan and Global PV Highlights." Tokyo: RTS Corporation.

Sherwood, L. (2013). “2013 Annual Updates and Trends Report.” Interstate Renewable Energy Council, October 2013, accessed October 2013. 
Shah, Vishal; Booream-Phelps, Jerimiah; Min, Susie. "2014 Outlook: Let the Second Gold Rush Begin.” Deutsche Bank Markets Research. January 6, 2014.

Shiao, M.J. (2013). GTM Research/Greentech Media, personal communication, December 26, 2013.

Solar Daily. (2013) "Japan Set to Become World’s Largest Solar Revenue Market in 2013." Solar Daily, http://www.solardaily.com/reports/Japan_Set to_Become_Worlds_Largest_Solar_Revenue_Mar ket in 2013 999.html, accessed June 2013.

Tsagas, I. (2014). "Japan Adds 4.58 GW of PV in Eight Months, FIT Cuts of 10\% Mooted." PV Magazine, http://www.pv-magazine.com/news/details/beitrag/japan-adds-458-gw-of-pv-in-eightmonths--fit-cuts-of-10-mooted_100014409/\#ixzz2v0x0nVdU, accessed March 2013.

UBS Investment Research (2013). “Global I/O: Solar Industry.” August 22, 2013. Zurich: UBS Investment Research.

Watanabe, C. (2013). "Japan Banks Ante Up to \$19 Billion Solar Market." Renewable Energy World, http://www.renewableenergyworld.com/rea/news/article/2013/02/japan-banks-ante-up-to19-billion-solar-market, accessed June 2013.

Wesoff, E. (2013). “Japan: The World's Hottest Solar Market in 2013.” GreentechMedia. Accessed June 12, 2013: http://www.greentechmedia.com/articles/read/Japan-The-WorldsHottest-Solar-Market-in2013?utm source=Daily\&utm medium=Headline\&utm campaign=GTMDaily.

Wile, R. (2013). "Japan is Now the Biggest Solar Market in the World." Business Insider, http://www.businessinsider.com/the-land-of-the-rising-sun-is-now-the-biggest-solar-market-inthe-world-2013-6, accessed June 2013.

Woodward, T. (2013a). "Renewable Energy - Analyst Reaction." Bloomberg New Energy Finance, August 2013, accessed September 2013.

Woodward, T. (2013b). “Japan - Solar - Research Note.” Bloomberg New Energy Finance, October 2013, accessed November 2013.

Yamada, H.; Yamaya, H.; Ikki, O. (2013). National Survey Report of PV Power Applications in Japan. Kawasaki City, Kanagawa, Japan: International Energy Agency (IEA), May 31, 2013.

Yamaya, H.; Ohigashi, T.; Matsukawa, H.; Ikki, O.; Kaizuka, I. (2013). "Feed-in Tariff Program and its Impact on PV Market in Japan." Presented at the 39th IEEE Photovoltaic Specialists Conference, June 16-21, 2013, Tampa, FL. 


\section{Appendix A. Japanese PV Prices and Costs-Top and Bottom $10^{\text {th }}$ Percentile, with Capacity-Weighted Averages}

Table A-1 shows the top and bottom 10\% of Japanese residential PV system hardware costs, soft costs, and other costs, along with the capacity-weighted average, among survey responses. Table A-2 shows the top and bottom 10\% of Japanese small commercial PV system hardware costs, soft costs, and other costs, along with the capacity-weighted average, among survey responses.

Table A-1. Soft Costs, Hardware Costs, and Other Costs for Japanese Residential PV, 1H13

\begin{tabular}{|c|c|c|c|c|c|c|c|c|c|c|c|c|c|c|c|c|c|c|}
\hline $\begin{array}{l}\text { All values are } \\
\text { expressed in } \\
2013 \$ / W\end{array}$ & $\frac{\frac{\dddot{\nu}}{3}}{\frac{\mathrm{g}}{\Sigma}}$ & 产 & 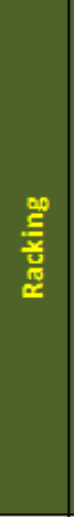 & 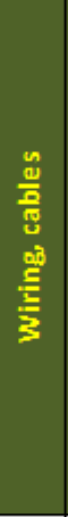 & 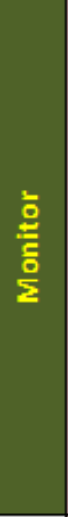 & 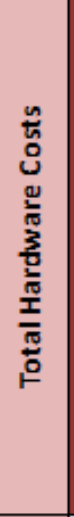 & 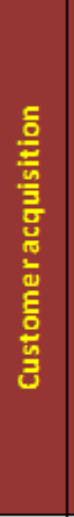 & 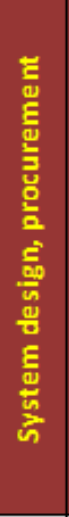 & 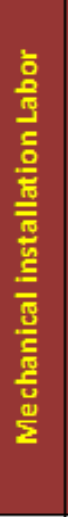 & 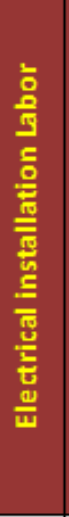 & 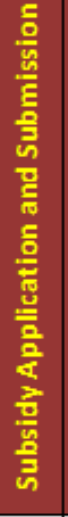 & 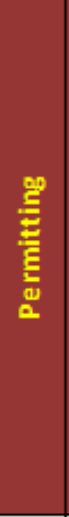 & 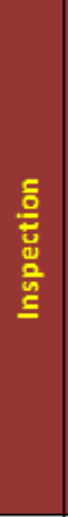 & 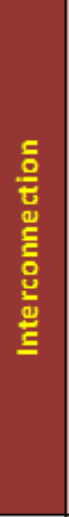 & 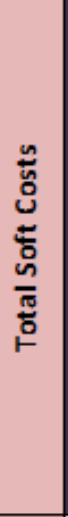 & 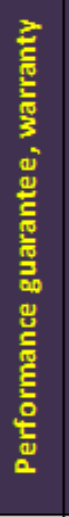 & 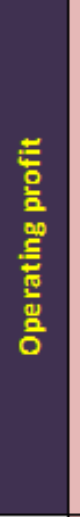 & 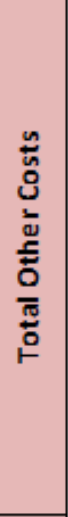 \\
\hline $\begin{array}{l}\text { copacity- } \\
\text { weighted } \\
\text { average } \\
\end{array}$ & 1.83 & 0.34 & 1.83 & 0.19 & 0.34 & 4.54 & 0.20 & 0.03 & 0.50 & 0.15 & 0.08 & 0.00 & 0.00 & 0.02 & 0.99 & 0.02 & 0.81 & 0.83 \\
\hline 10th percentile & 1.56 & 0.26 & 1.56 & 0.12 & 0.26 & 3.77 & 0.03 & 0.01 & 0.29 & 0.09 & 0.05 & 0.00 & 0.00 & 0.01 & 0.48 & 0.01 & 0.37 & 0.38 \\
\hline 90th percentile & 2.19 & 0.47 & 2.19 & 0.28 & 0.47 & 5.58 & 0.46 & 0.04 & 0.77 & 0.28 & 0.15 & 0.00 & 0.00 & 0.03 & 1.73 & 0.03 & 1.12 & 1.15 \\
\hline
\end{tabular}

Table A-2. Soft Costs, Hardware Costs, and Other Costs for Japanese Small Commercial PV, 1H13

\begin{tabular}{|c|c|c|c|c|c|c|c|c|c|c|c|c|c|c|c|c|c|c|}
\hline $\begin{array}{l}\text { All values are } \\
\text { expressed in } \\
2013 \$ / W\end{array}$ & $\frac{\frac{\omega}{5}}{\frac{g}{5}}$ & 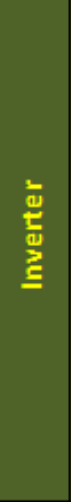 & 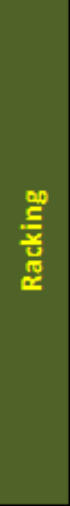 & 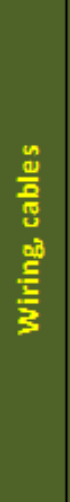 & 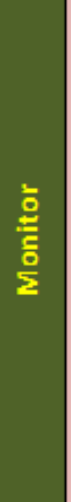 & 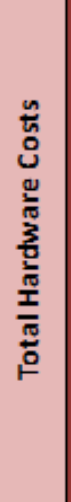 & 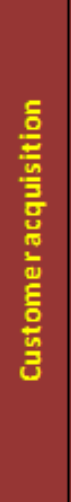 & 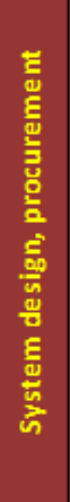 & 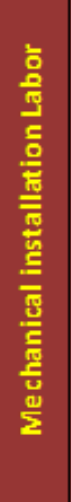 & 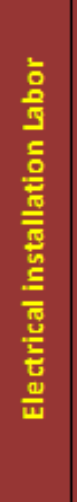 & 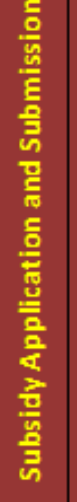 & 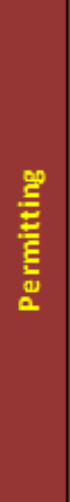 & 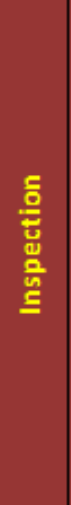 & 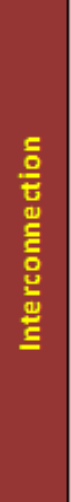 & 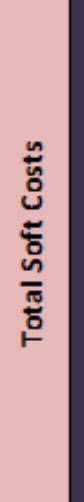 & 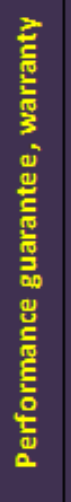 & 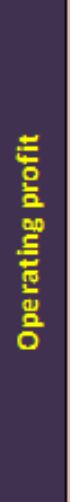 & 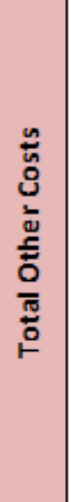 \\
\hline \begin{tabular}{|l|} 
capacity- \\
weighted \\
average \\
\end{tabular} & 1.54 & 0.31 & 0.16 & 0.16 & 0.03 & 2.19 & 0.02 & 0.00 & 0.18 & 0.07 & 0.00 & 0.00 & 0.00 & 0.00 & 0.28 & 0.00 & 0.95 & 0.95 \\
\hline 10th percentile & 125 & 0.21 & 0.11 & 0.10 & 0.00 & 1.68 & 0.01 & 0.00 & 0.12 & 0.03 & 0.00 & 0.00 & 0.00 & 0.00 & 0.16 & 0.00 & 0.48 & 0.48 \\
\hline 90th percentile & 2.08 & 0.40 & 0.26 & 0.26 & 0.06 & 3.06 & 0.24 & 0.01 & 0.50 & 0.18 & 0.03 & 0.01 & 0.00 & 0.01 & 0.97 & 0.01 & 1.29 & 1.30 \\
\hline
\end{tabular}




\section{Appendix B. Modeled PV Economic-Return Scenarios}

We modeled several scenarios for residential systems to show how they might fare through a hypothetical 25-year life span. We modeled three different households with low $(2,700 \mathrm{kWh} /$ year $)$, medium $(3,600 \mathrm{kWh} /$ year $)$, and high $(4,500 \mathrm{kWh} /$ year $)$ electricity consumption. ${ }^{22}$ We modeled various insolation levels, ranging from $1,170 \mathrm{kWh} / \mathrm{m} 2$ to 1491 $\mathrm{kWh} / \mathrm{m} 2$. We assumed tiered electricity rates similar to those of TEPCO, where the marginal retail electricity prices rise in three steps (less than $120 \mathrm{kWh} /$ month, less than $300 \mathrm{kWh} / \mathrm{month}$, and greater than or equal to $300 \mathrm{kWh} /$ month), with increasing consumption resulting in larger economic benefits for PV households. We also varied the initial PV system price, ranging from the $25^{\text {th }}$ to the $75^{\text {th }}$ percentile of the price distribution in our survey results. We assumed an inverter replacement for all systems in year 15 , annual module degradation of $0.5 \%$, and a DCAC derate factor of 0.77 .

Given the uncertainty about the valuation of PV electricity after the end of the regular FiT payments, we modeled the NPV and RoR of the PV system after the first 10 years of operation (40\%-75\% of the initial investment has been recuperated at this point) and five alternative remuneration futures:

1. All electricity generated by the PV system after the expiration of the initial FiT is valued at $\$ 0.24 / \mathrm{kWh}$, which equals the average electricity price of the three retail tiers. The household would have to pay its traditional electricity bill but with a secure secondary income stream until the end of the system lifetime in year 25. Households with high electricity consumption (paying high marginal electricity prices as a result) will not fare as well as households with low electricity consumption. In this scenario, systems in the sunny South would benefit under all examined conditions from this policy future, while expensive systems in the less sunny North show less benefit.

2. All electricity generated by the PV system after the expiration of the initial FiT is valued at $\$ 0.10 / \mathrm{kWh}$, which may mirror average wholesale electricity prices. Only under one of the examined scenarios would it be possible to recover the initial investment costs of the PV system in this potential future policy environment.

3. No extra payments are made to the household that owns the PV system after the expiration of the initial FiT, but the household is allowed to continue an annual virtual netting of their PV generation with their total electricity consumption. Only households in a sunny environment with high (thus expensive) electricity consumption are able to make a consistent economic profit in this scenario.

4. Net metering is extended through the end of the system lifetime (as is the case in Scenario 3), but in this scenario excess generation receives a continued remuneration of $\$ 0.24 / \mathrm{kWh}$ (similar to the average retail electricity price). In this scenario, all owners of low-priced systems can make an economic profit, not just those in sunny regions, although better insolation enables more expensive systems to produce a profit. Owners with high electricity consumption do not have additional benefits from the valuation of excess generation in this scenario because they have already used all the electricity to

\footnotetext{
${ }^{22}$ The higher the consumption, the less excess electricity available to sell under the FiT.
} 
offset their own consumption. Such customers might prefer a larger PV system than the assumed 5-kW system.

5. In this scenario, net metering continues as in Scenario 4, but excess electricity is only valued at a hypothetical average wholesale price of $\$ 0.10 / \mathrm{kWh}$ instead of the higher retail electricity price. Economic profits and losses are distributed in a similar manner as in Scenario 4; one exception is that customers with low-priced systems and low electricity consumption in regions with lower insolation face an economic loss in Scenario 5 but not Scenario 4.

Table B-1 shows the modeled results for residential systems and Table B-2 for commercial systems. Table B-3 shows assumptions pertaining to the residential and commercial analyses, including real discount rate, annual energy price and tax escalation, and excess electricity value after the FiT period. 
Table B-1. Scenarios for Japanese Residential PV Economic Returns

\begin{tabular}{|c|c|c|c|c|c|c|}
\hline \multicolumn{7}{|c|}{ Residential Systems } \\
\hline \multirow{2}{*}{$\begin{array}{l}\text { Annual insolation } \\
\text { Domestic annual electricity } \\
\text { consumption }\end{array}$} & \multicolumn{3}{|c|}{$1306 \mathrm{kWh} / \mathrm{m} 2$ global horizontal } & \multicolumn{3}{|c|}{$1491 \mathrm{kWh} / \mathrm{m} 2$ global horizontal } \\
\hline & $2700 \mathrm{kWh}$ & $3600 \mathrm{kWh}$ & $4500 \mathrm{kWh}$ & $2700 \mathrm{kWh}$ & $3600 \mathrm{kWh}$ & $4500 \mathrm{kWh}$ \\
\hline PV system price & \multicolumn{6}{|c|}{ Net present value after 10 years of FiT } \\
\hline 4.37 \$/W (25th percentile) & $-\$ 6,470$ & $-\$ 8,424$ & $-\$ 8,953$ & $-\$ 5,089$ & $-\$ 6,158$ & $-\$ 6,893$ \\
\hline 4.99 \$/W (75th percentile) & $-\$ 9,831$ & $-\$ 11,785$ & $-\$ 12,314$ & $-\$ 8,450$ & $-\$ 9,519$ & $-\$ 10,254$ \\
\hline \multirow[t]{2}{*}{$4.64 \$ / W$ (mean) } & $-\$ 8,094$ & $-\$ 10,047$ & $-\$ 10,577$ & $-\$ 6,712$ & $-\$ 7,781$ & $-\$ 8,516$ \\
\hline & \multicolumn{6}{|c|}{ Rate of Return } \\
\hline $4.37 \$ / W$ (25th percentile) & $-30 \%$ & $-39 \%$ & $-42 \%$ & $-24 \%$ & $-29 \%$ & $-32 \%$ \\
\hline 4.99 \$/W (75th percentile) & $-40 \%$ & $-47 \%$ & $-49 \%$ & $-34 \%$ & $-38 \%$ & $-41 \%$ \\
\hline $4.64 \$ / W$ (mean) & $-35 \%$ & $-43 \%$ & $-46 \%$ & $-29 \%$ & $-34 \%$ & $-37 \%$ \\
\hline PV system price & \multicolumn{6}{|c|}{$\begin{array}{c}\text { Net present value with flat electricity price of } \$ .24 / \mathrm{kWh} \text { for total } \\
\text { generated electricity year } 11-25\end{array}$} \\
\hline 4.37 \$/W (25th percentile) & $\$ 4,211$ & $\$ 2,258$ & $\$ 1,728$ & $\$ 8,153$ & $\$ 7,084$ & $\$ 6,349$ \\
\hline 4.99 \$/W (75th percentile) & $\$ 850$ & $-\$ 1,104$ & $-\$ 1,633$ & $\$ 4,792$ & $\$ 3,723$ & $\$ 2,988$ \\
\hline \multirow[t]{2}{*}{$4.64 \$ / W$ (mean) } & $\$ 2,588$ & $\$ 634$ & $\$ 105$ & $\$ 6,529$ & $\$ 5,460$ & $\$ 4,725$ \\
\hline & \multicolumn{6}{|c|}{ Rate of Return } \\
\hline 4.37 \$ $\mathrm{W}$ (25th percentile) & $20 \%$ & $10 \%$ & $8 \%$ & $38 \%$ & $33 \%$ & $29 \%$ \\
\hline 4.99 \$/W (75th percentile) & $3 \%$ & $-4 \%$ & $-7 \%$ & $19 \%$ & $15 \%$ & $12 \%$ \\
\hline $4.64 \$ / W$ (mean) & $11 \%$ & $3 \%$ & $0 \%$ & $28 \%$ & $24 \%$ & $20 \%$ \\
\hline PV system price & \multicolumn{6}{|c|}{$\begin{array}{l}\text { Net present value with flat electricity price of } \$ .10 / \mathrm{kWh} \text { for total } \\
\qquad \text { generated electricity year } 11-25\end{array}$} \\
\hline 4.37 \$/W (25th percentile) & $-\$ 2,019$ & $-\$ 3,973$ & $-\$ 4,502$ & $\$ 429$ & $-\$ 640$ & $-\$ 1,375$ \\
\hline 4.99 \$/W (75th percentile) & $-\$ 5,381$ & $-\$ 7,334$ & $-\$ 7,864$ & $-\$ 2,933$ & $-\$ 4,002$ & $-\$ 4,737$ \\
\hline \multirow[t]{2}{*}{$4.64 \$ / W$ (mean) } & $-\$ 3,643$ & $-\$ 5,597$ & $-\$ 6,126$ & $-\$ 1,195$ & $-\$ 2,264$ & $-\$ 2,999$ \\
\hline & \multicolumn{6}{|c|}{ Rate of Return } \\
\hline 4.37 \$/W (25th percentile) & $-9 \%$ & $-18 \%$ & $-21 \%$ & $2 \%$ & $-3 \%$ & $-6 \%$ \\
\hline 4.99 \$/W (75th percentile) & $-22 \%$ & $-29 \%$ & $-32 \%$ & $-12 \%$ & $-16 \%$ & $-19 \%$ \\
\hline $4.64 \$ / W$ (mean) & $-16 \%$ & $-24 \%$ & $-26 \%$ & $-5 \%$ & $-10 \%$ & $-13 \%$ \\
\hline PV system price & \multicolumn{6}{|c|}{$\begin{array}{l}\text { Net present value with continued net-metering in years 11-25 } \\
\text { without excess electricity revenue }\end{array}$} \\
\hline 4.37 \$/W (25th percentile) & $\$ 36$ & $\$ 584$ & $\$ 2,449$ & $\$ 1,417$ & $\$ 2,850$ & $\$ 5,006$ \\
\hline 4.99 \$/W (75th percentile) & $-\$ 3,325$ & $-\$ 2,777$ & $-\$ 912$ & $-\$ 1,944$ & $-\$ 511$ & $\$ 1,645$ \\
\hline \multirow[t]{2}{*}{$4.64 \$ / W$ (mean) } & $-\$ 1,588$ & $-\$ 1,039$ & $\$ 825$ & $-\$ 207$ & $\$ 1,227$ & $\$ 3,382$ \\
\hline & \multicolumn{6}{|c|}{ Rate of Return } \\
\hline $4.37 \$ / W$ (25th percentile) & $0 \%$ & $3 \%$ & $11 \%$ & $7 \%$ & $13 \%$ & $23 \%$ \\
\hline 4.99 \$/W (75th percentile) & $-13 \%$ & $-11 \%$ & $-4 \%$ & $-8 \%$ & $-2 \%$ & $7 \%$ \\
\hline 4.64 \$/W (mean) & $-7 \%$ & $-4 \%$ & $4 \%$ & $-1 \%$ & $5 \%$ & $15 \%$ \\
\hline
\end{tabular}




\begin{tabular}{|c|c|c|c|c|c|c|}
\hline \multicolumn{7}{|c|}{ Residential Systems } \\
\hline Annual insolation & \multicolumn{3}{|c|}{ 1306kWh/m2 global horizontal } & \multicolumn{3}{|c|}{$1491 \mathrm{kWh} / \mathrm{m} 2$ global horizontal } \\
\hline $\begin{array}{l}\text { Domestic annual electricity } \\
\text { consumption }\end{array}$ & $2700 \mathrm{kWh}$ & $3600 \mathrm{kWh}$ & $4500 \mathrm{kWh}$ & $2700 \mathrm{kWh}$ & $3600 \mathrm{kWh}$ & $4500 \mathrm{kWh}$ \\
\hline PV system price & \multicolumn{6}{|c|}{$\begin{array}{l}\text { Net present value with continued net-metering in years } 11-25 \text { and } \\
\text { flat electricity price of } \$ .24 / \mathrm{kWh} \text { for excess generated electricity } \\
\text { year } 11-25\end{array}$} \\
\hline 4.37 \$/W (25th percentile) & $\$ 5,178$ & $\$ 3,515$ & $\$ 2,449$ & $\$ 8,023$ & $\$ 7,245$ & $\$ 7,189$ \\
\hline 4.99 \$/W (75th percentile) & $\$ 1,817$ & $\$ 154$ & $-\$ 912$ & $\$ 4,662$ & $\$ 3,883$ & $\$ 3,827$ \\
\hline \multirow[t]{2}{*}{$4.64 \$ / W$ (mean) } & $\$ 3,555$ & $\$ 1,892$ & $\$ 825$ & $\$ 6,399$ & $\$ 5,621$ & $\$ 5,565$ \\
\hline & \multicolumn{6}{|c|}{ Rate of Return } \\
\hline 4.37 \$/W (25th percentile) & $24 \%$ & $16 \%$ & $11 \%$ & $37 \%$ & $34 \%$ & $33 \%$ \\
\hline 4.99 \$/W (75th percentile) & $7 \%$ & $1 \%$ & $-4 \%$ & $19 \%$ & $16 \%$ & $15 \%$ \\
\hline $4.64 \$ / W$ (mean) & $15 \%$ & $8 \%$ & $4 \%$ & $28 \%$ & $24 \%$ & $24 \%$ \\
\hline PV system price & \multicolumn{6}{|c|}{$\begin{array}{l}\text { Net present value with continued net-metering in years } 11-25 \text { and } \\
\text { flat electricity price of } \$ .10 / \mathrm{kWh} \text { for excess generated electricity } \\
\text { year } 11-25\end{array}$} \\
\hline 4.37 \$/W (25th percentile) & $\$ 2,179$ & $\$ 1,806$ & $\$ 2,449$ & $\$ 4,170$ & $\$ 4,681$ & $\$ 5,915$ \\
\hline 4.99 \$/W (75th percentile) & $-\$ 1,183$ & $-\$ 1,556$ & $-\$ 912$ & $\$ 808$ & $\$ 1,320$ & $\$ 2,554$ \\
\hline \multirow[t]{2}{*}{$4.64 \$ / W$ (mean) } & $\$ 555$ & $\$ 182$ & $\$ 825$ & $\$ 2,546$ & $\$ 3,058$ & $\$ 4,292$ \\
\hline & \multicolumn{6}{|c|}{ Rate of Return } \\
\hline 4.37 \$/W (25th percentile) & $10 \%$ & $8 \%$ & $11 \%$ & $19 \%$ & $22 \%$ & $27 \%$ \\
\hline 4.99 \$/W (75th percentile) & $-5 \%$ & $-6 \%$ & $-4 \%$ & $3 \%$ & $5 \%$ & $10 \%$ \\
\hline $4.64 \$ / \mathrm{W}$ (mean) & $2 \%$ & $1 \%$ & $4 \%$ & $11 \%$ & $13 \%$ & $19 \%$ \\
\hline
\end{tabular}


Table B-2. Scenarios for Japanese Commercial PV Economic Returns

\begin{tabular}{|c|c|c|}
\hline \multicolumn{3}{|c|}{ Commercial systems } \\
\hline Annual global horizontal insolation & 1306kWh/m2 & $1491 \mathrm{kWh} / \mathrm{m} 2$ \\
\hline \begin{tabular}{|c|} 
PV system price \\
\end{tabular} & \multicolumn{2}{|c|}{ Net present value after 20 years of FiT } \\
\hline 3.31 \$/W (25th percentile) & $\$ 143,278$ & $\$ 181,009$ \\
\hline $4.16 \$ / W(75$ th percentile) & $\$ 98,116$ & $\$ 135,846$ \\
\hline \multirow[t]{2}{*}{$3.59 \$ / W$ (mean) } & $\$ 129,103$ & $\$ 166,834$ \\
\hline & \multicolumn{2}{|c|}{ Rate of Return } \\
\hline 3.31 \$/W (25th percentile) & $89 \%$ & $113 \%$ \\
\hline $4.16 \$ / W(75$ th percentile) & $48 \%$ & $66 \%$ \\
\hline $3.59 \$ / W$ (mean) & $74 \%$ & $96 \%$ \\
\hline
\end{tabular}

Table B-3. Assumptions in Economic Modeling of Japanese PV Systems

\begin{tabular}{r|r|r|}
\multicolumn{2}{|c|}{ Assumptions } \\
\hline Real Discount Rate (based on real interest rate for Japan, World Bank Data) & $2.30 \%$ \\
\hline Real Annual Electricity Escalation (mean of 2002-2012 IEA "Energy Prices and Taxes") & $0.22 \%$ \\
\hline Excess electricity value after FiT period [\$2013/kWh] & 0.24 and 0.10 \\
\hline
\end{tabular}




\section{Appendix C. PV System Costs by Business Model and Location}

\section{Residential Costs by Business Model}

We compared residential PV costs for installers who were more focused on PV installations than other business lines (with greater than two thirds of their business activity focused on PV), those who were less focused on PV than other business lines (with less than one third of their business activity focused on PV), and those who fell between the other two categories (Figure C-1). This confirmed our hypothesis that residential PV customer-acquisition and system-design costs are lower for businesses not primarily focused on PV.

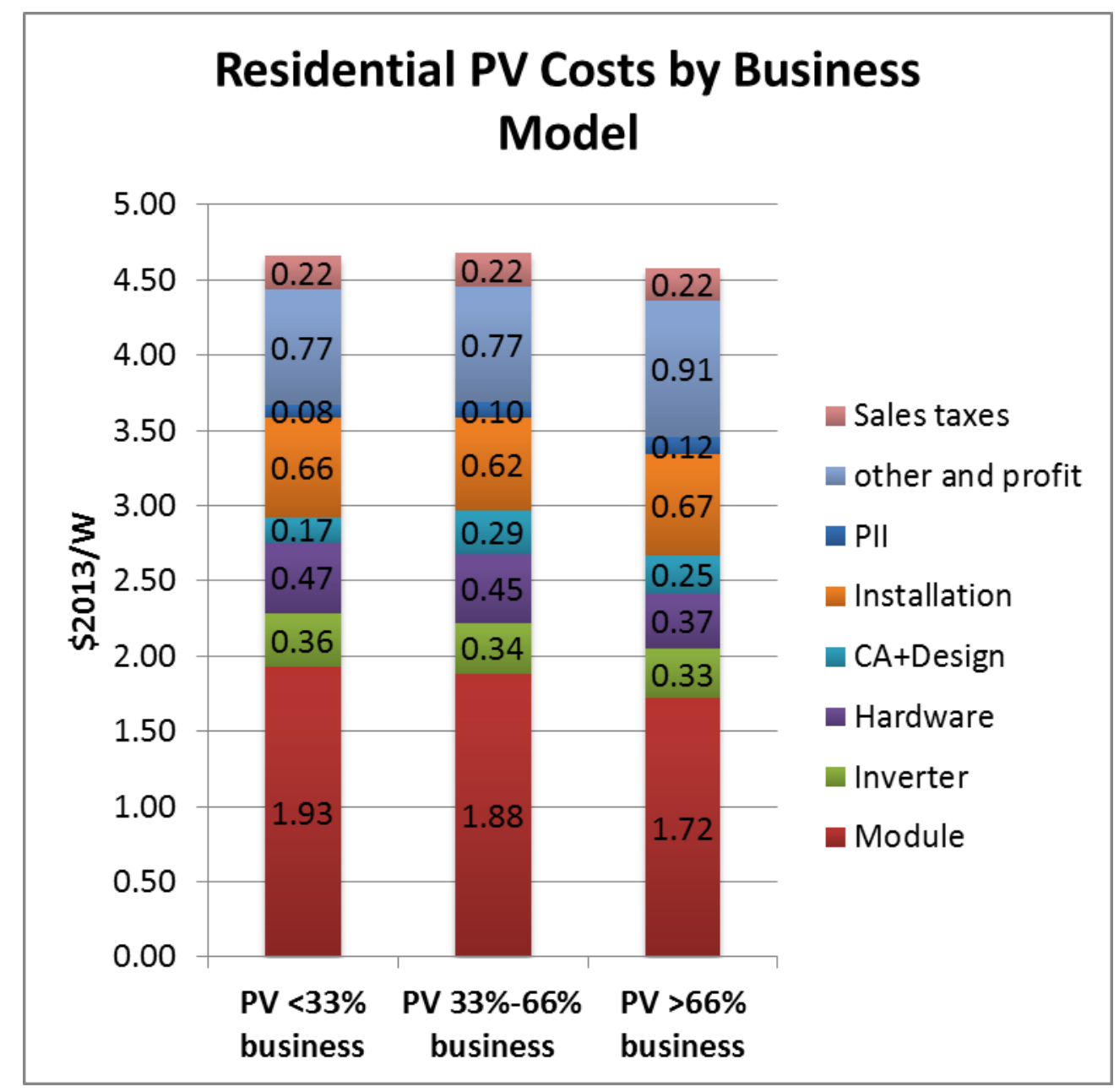

Figure $\mathrm{C}-1$. Japanese residential PV costs by business model

\section{Residential Costs by Prefecture}

We analyzed PV costs by prefecture for the eight prefectures encompassing our area of research (Figure C-2). 


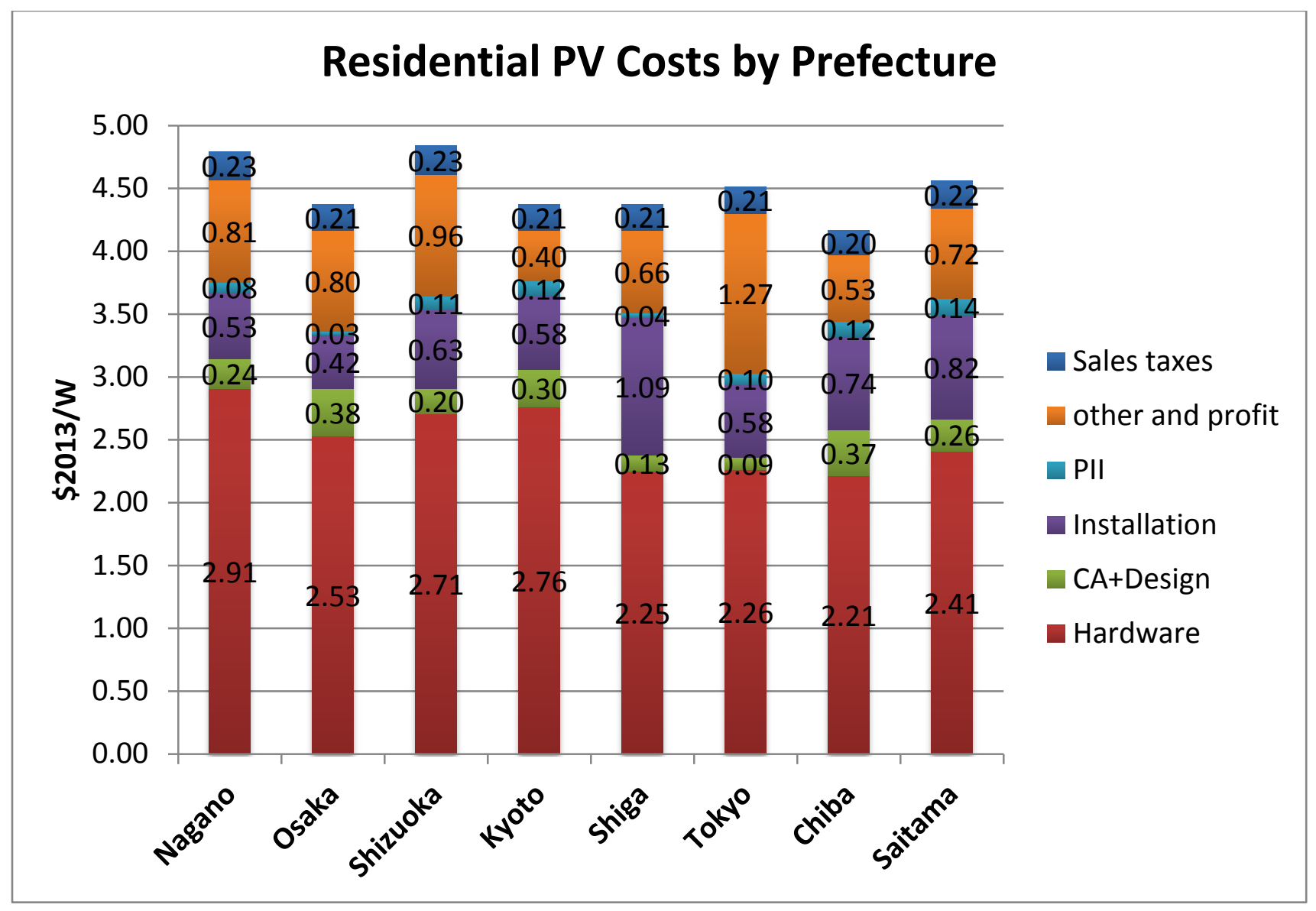

Figure C-2. Japanese residential PV costs by prefecture for the eight prefectures studied

\section{Commercial Costs by Business Model}

We compared commercial PV costs for installers who were more focused on PV installations than other business lines (with greater than two thirds of their business activity focused on PV), those who were less focused on PV than other business lines (with less than one third of their business activity focused on PV), and those who fell between the other two categories. We found that installers not primarily focused on PV were at a disadvantage insofar as paying a premium for hardware, but they more than absorbed the extra cost through lower profit margins (Figure C$3)$. 


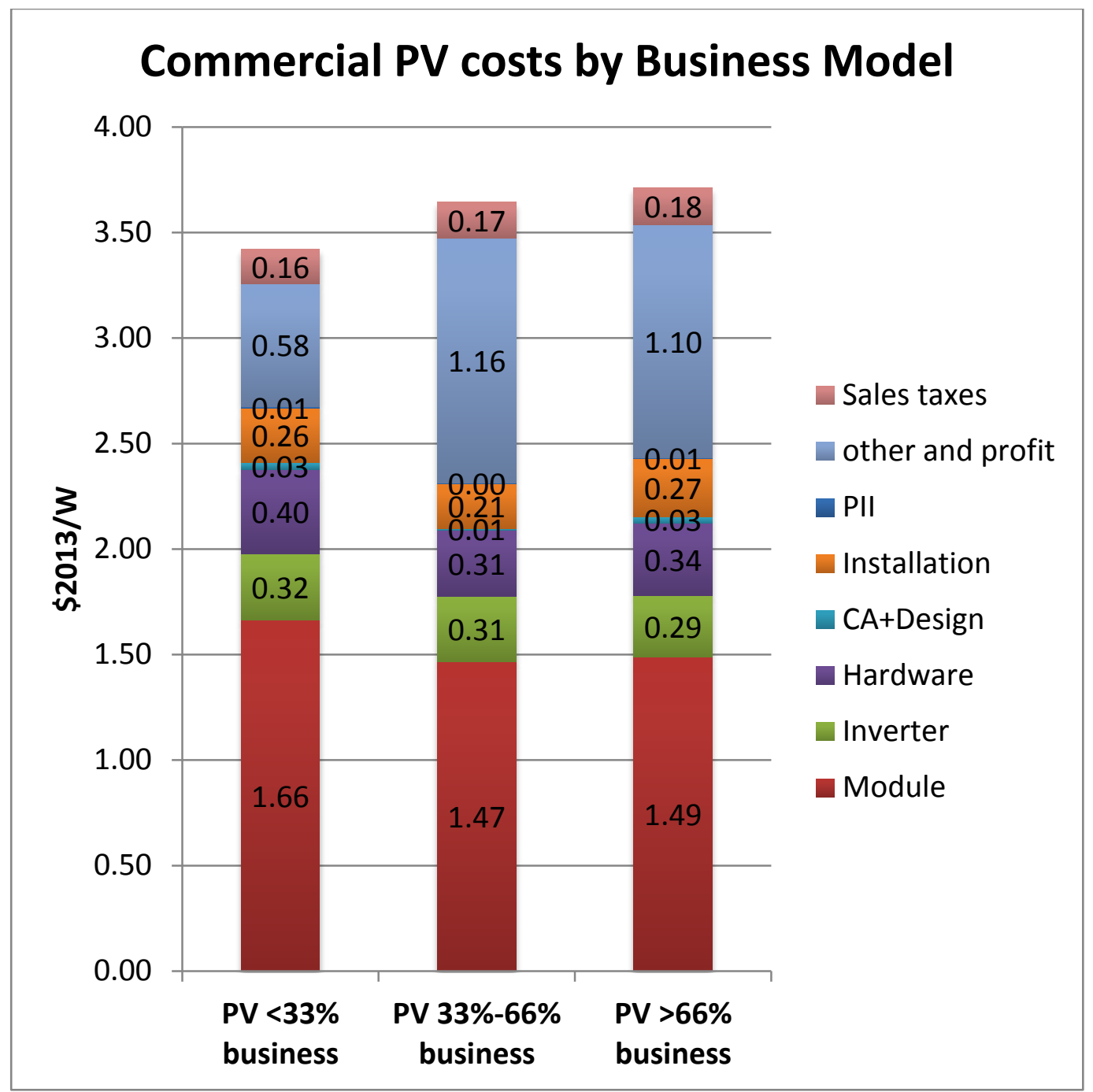

Figure C-3. Japanese commercial PV costs by business model

\section{Commercial Costs by Prefecture}

We analyzed PV costs by prefecture for the eight prefectures encompassing our area of research (Figure C-4). 


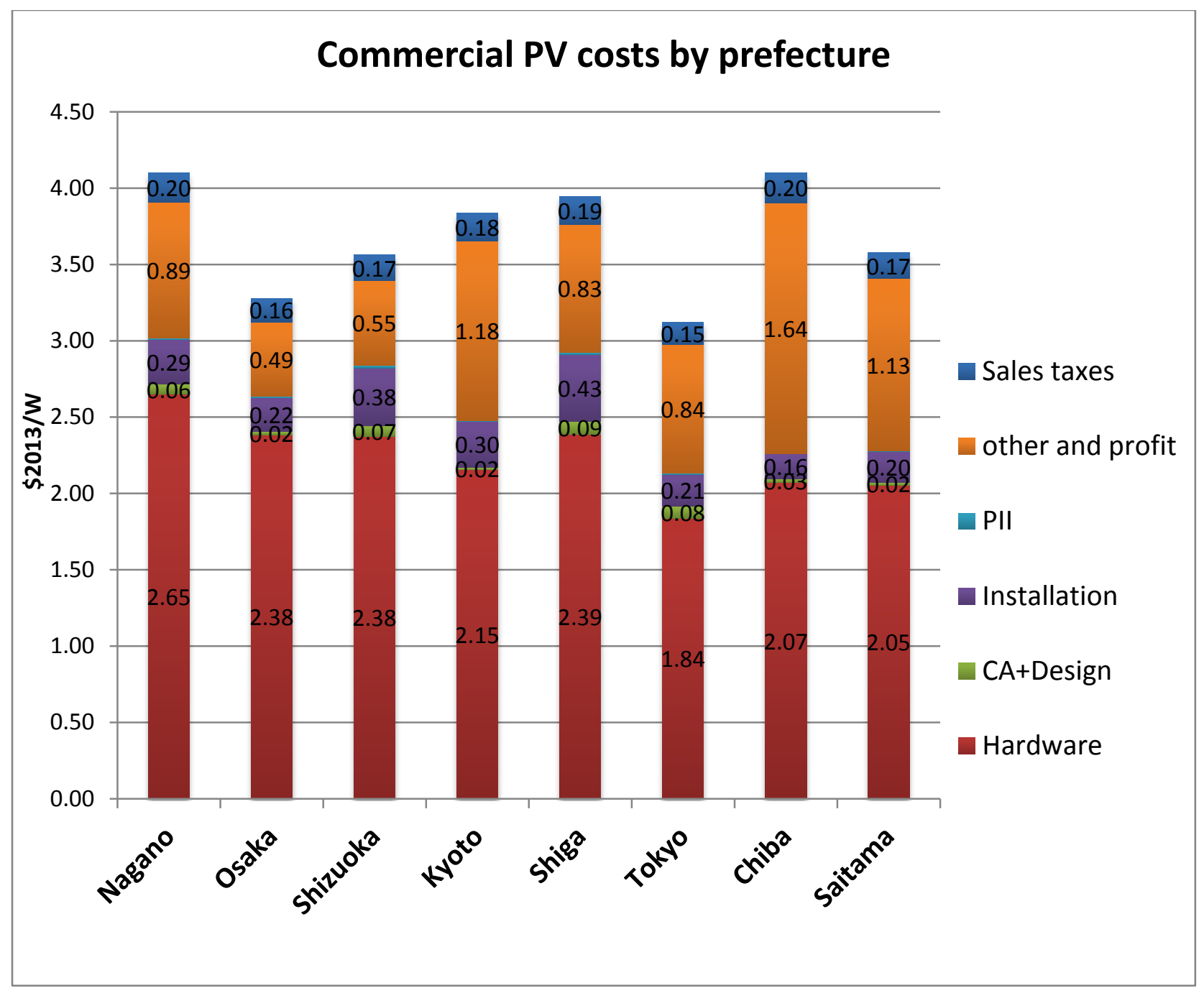

Figure C-4. Japanese commercial PV costs by prefecture for the eight prefectures studied 


\section{Appendix D. Japan Questionnaire Instrument}

\section{Number of PV Systems Installed and Cost Breakdown}

1. For the following customer segments, please provide the number of PV systems installed in FY2013 and the number of total megawatts installed in FY2013 (April 2012-March 2013)
a. Residential
b. Small commercial rooftop $(<50 \mathrm{~kW})$
c. Large commercial rooftop $(>50 \mathrm{~kW}<1 \mathrm{MW})$
d. Mega solar (utility-scale field 1MW and up)
e. Off-grid installations
f. Total

2. What was the average installed cost (not end consumer price) of systems completed in FY2013? (in $¥ / W$ )
a. Residential:
b. Small commercial $(<50 \mathrm{~kW})$ :
c. Large commercial $(>50 \mathrm{~kW})$ :
d. Large commercial $(>250 \mathrm{~kW})$ :

3. What was the average end consumer price of systems completed in FY2013? (in $¥ / \mathrm{W}$ )
a. Residential:
b. Small commercial $(<50 \mathrm{~kW})$ :
c. Large commercial $(>50 \mathrm{~kW})$ :
d. Large commercial $(>250 \mathrm{~kW})$ :

4. Of the total installed cost above, what percentage was attributable to each of the following cost categories? [Note: Totals must add to $100 \%$ ]

a. Kits and/or components
i. Modules
ii. Inverter
iii. Other hardware and materials (racking, wiring, etc.)

b. Process and business soft costs including:
i. Customer acquisition
ii. System and kit design/procurement (excluding any and all hardware costs)
iii. Permitting
iv. Inspection
v. Interconnection
vi. Financing and contracting
vii. Installation
viii. Performance and warranty
ix. Obtaining incentives (including paperwork)

5. From how many distributors and kit suppliers do you typically get a bid before purchasing a kit? What are the key factors that lead you to decide to purchase from one specific distributor/kit supplier instead of other distributors/kit vendors? 


\section{Customer Acquisition}

6. How many bids did you prepare in FY2013, or prior, for residential systems with a planned installation date in FY2013? (number of individual bids that could lead to a contract, including multiple bids prepared for the same customer)

7. What was the total cost of residential and/or commercial (small and/or large) customer acquisition activities in FY2013 (including sales calls, site visits, travel time to and from the site, contract negotiation with system host/owner, and bid/pro-forma preparation, including marketing/advertising but not system design)?

8. How much of the above was marketing and advertising (the total marketing and advertising budget in FY2013)?

9. What was the total cost of system design in FY2013? (includes all system design activities both before and after the contract is signed)

a. How much of this was kit procurement?

10. What technologies do you use in customer acquisition, system design and bid preparation (including, but not limited to, satellite imaging and web based tools)?

\section{Permitting, Inspection, and Interconnection}

11. On average in FY2013, how many labor hours per residential/commercial (small and/or large) PV installation (both full time employees and contract labor) were spent on the following?

a. Preparing a permit package for METI FiT application (including determining permitting requirements, travel time to site/verification, drawing system plans, structural calculations, certification details, and delays)

b. What permitting fees did you have to pay? (per install, variance by size of install)

c. Submitting the permit package (including travel time to and from the METI office and wait time at the permitting office)

d. Completing the interconnection process (including paperwork, discussions with local utility, travel time to and from the site, wait time for representative from utility, and physical interconnection)

e. Completing the permitting inspection (including paperwork, travel time to and from the site, wait time for inspector, multi-jurisdiction, physical inspection and measurements, and communicating inspection report to customers, wait time for approval)

f. Applying for and receiving all local financial incentives (including determining eligibility, paperwork, travel time to and from the site, wait time for inspector physical inspection and amount of time until financial incentives are received) 


\section{Financing and Contracting}

12. Do you offer financing to your residential and/or commercial (small and/or large) customers? (yes/no)

13. For the total number of residential and/or commercial (small and/or large) PV installations you completed in FY2013, please provide a percentage breakdown for how they were financed (must add to $100 \%$ ).

a. Direct cash purchase

b. Loan payment of any form

14. For the financing options listed in the previous question, on average in FY2013, how many labor hours per residential PV installation (both employees and contract labor) were spent working with the providers of the funds?

a. Direct cash purchase

b. Installer-assisted financing from commercial bank

c. Installer-assisted financing from government loan program

d. Third-party lease agreement

e. Third-party power purchase agreement

\section{Installation, Performance and Warranty}

15. On average in FY2013, please provide the total number of labor hours per residential and/or commercial (small and/or large) PV installation (both employees and contract labor) spent on installation (includes installation only, not travel time to and from the site).

16. For the total number of labor hours reported in the previous question, what was the percentage breakdown of electrician vs. non-electrician labor hours used in installation per residential and/or commercial (small and/or large) PV system in FY2013?

a. Electrician labor hours

b. Non-electrician (installer) labor hours

17. For the average total number of labor hours reported in the previous question, what is the average size of system (how many $\mathrm{kW}$ )? 